\title{
AN EVALUATION OF THE ENVIRONMENTAL FATE AND BEHAVIOF' OF MUNITIONS MATERIEL (TNT, RDX) IN SOIL AND PLANT SYSTEMS
}

Environmental Fate And Behavior of RDX

\section{FINAL REPORT}

Dominic A. Cataldo, Ph. D

Scott D. Harvey, Ph. D.

Robert J. Fellows, Ph. D

AUGUST 1990

Supported by:

\section{U.S. Army Biomedical Research and Development Laboratory}

Fort Detrick, Frederick, Maryland 21701-5010

\section{Project Order No. 88PP8853}

Pacific Northwest Laboratory

Richland, Washington 99352

Operated for the U.S. Department of Energy

by Battelle Memorial Institute

\section{Project Officer: Wayne R. Mitchell}

U.S. Army Biomedical Research and

$$
\text { Development Laboratory }
$$

Fort Detrick, Frederick, Maryland 21701-5010

Approved for public release;

distribution unlimited 


\begin{tabular}{|c|c|c|c|}
\hline \multicolumn{3}{|c|}{ REPORT DOCUMENTATION PAGE } & $\begin{array}{l}\text { Form Approved } \\
\text { OMB No.0704-0188 }\end{array}$ \\
\hline \multicolumn{2}{|c|}{$\begin{array}{l}\text { 1a REP JRT SECURITY CLASSIFICATION } \\
\text { Unclassified }\end{array}$} & \multicolumn{2}{|l|}{ Ib RESTRICTIVE MARKINGS } \\
\hline \multicolumn{2}{|c|}{ 2a. SECURITY CLASSIFICATION AUTHOFITY } & \multirow{2}{*}{\multicolumn{2}{|c|}{$\begin{array}{l}3 \text { DISTRIBUTION/AVAILABILITY OF REPORT } \\
\text { Approved for public release; } \\
\text { distribution unlimited }\end{array}$}} \\
\hline \multicolumn{2}{|c|}{ 2b. DECLASSIFICATIONIDOWNGRADING SCHEDULE } & & \\
\hline \multicolumn{2}{|c|}{$\begin{array}{l}\text { 4. PERFORMING ORGANIZATION REPCRT NUMBER(S) } \\
\text { Pacific Nortinwest Laboratory }\end{array}$} & \multicolumn{2}{|c|}{ 5. MONITORING ORGANIZATION RE:PORT NUMBER(S) } \\
\hline \multicolumn{2}{|c|}{\begin{tabular}{l|l} 
6a. NAME OF PERFORMING ORGANIZATION & $\begin{array}{c}\text { 6b. OFFICE SYMBOL } \\
\text { (If applicable) }\end{array}$ \\
Pacific Northwest Laboratory &
\end{tabular}} & \multicolumn{2}{|c|}{ 7a. NAME OF MONITORING ORGANIZATION } \\
\hline \multicolumn{2}{|c|}{$\begin{array}{l}\text { 6c. ADDRESS (City, State, and ZIP Code) } \\
\text { Richland, Washington } 99352\end{array}$} & \multicolumn{2}{|l|}{ 7b. ADDRESS (City, State, and ZIP Code) } \\
\hline \multicolumn{2}{|c|}{$\begin{array}{l}\text { 8a. NAME OF FUNDING/SPONSORING } \\
\text { ORGANIZATION U.S. Army Medical } \\
\text { Research \& Development Command }\end{array}$} & \multicolumn{2}{|c|}{$\begin{array}{l}\text { 9. PROCUREMENT INSTRUMENT IDENTIFICATION NUMBER } \\
\text { Arny Project Order No. 88PP } 8853\end{array}$} \\
\hline \multirow{2}{*}{\multicolumn{2}{|c|}{$\begin{array}{l}\text { 8C. ADDPESS (City, State, and ZIP Code) } \\
\text { Fort Detrick } \\
\text { Frederick, Maryland 21701-5012 }\end{array}$}} & \multicolumn{2}{|c|}{ 10. SO JRCE OF FUNDING NUMBERS } \\
\hline & & \multicolumn{2}{|c|}{ 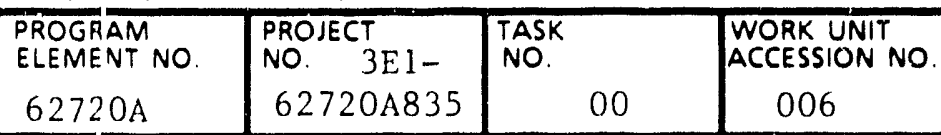 } \\
\hline \multicolumn{4}{|c|}{$\begin{array}{l}\text { 11. TITLE (Include Security Classification) } \\
\text { (U) An Evaluation of the Environmental Fate and Be!lavior of Munitions Materiel (TNT, RDX) } \\
\text { in Soil and Plant Systems }\end{array}$} \\
\hline \multicolumn{4}{|c|}{$\begin{array}{l}\text { 12. PERSONAL AUTHOR(S) } \\
\text { Dominic A. Cataldo, Scott D. Harvey, Robert J. Fellows }\end{array}$} \\
\hline \multicolumn{4}{|c|}{ 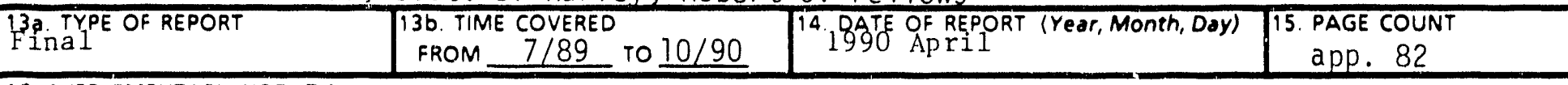 } \\
\hline \multicolumn{4}{|c|}{$\begin{array}{l}\text { 16. SUPPLEMENTARY NOTATION } \\
\text { Subtitle: Environmental Fate and Behavior of } \mathrm{RDX}\end{array}$} \\
\hline 17. COSATI CODES & \multirow{3}{*}{\multicolumn{3}{|c|}{$\begin{array}{l}\text { 18. SUBJECT TERMS (Continue on reverse if necessary and identify by block } \\
\text { RA 3; Munitions; Bioavailability; Plant uptake; } \\
\text { Environmental fate; TNT; RDX; PO }\end{array}$}} \\
\hline FIELD & & & \\
\hline 06 & & & \\
\hline \multirow{2}{*}{\multicolumn{4}{|c|}{$\begin{array}{l}\text { 19. ABSTRACT (Continue on reverse if necessary and identify by block number) } \\
\text { The objective of the present investigation was to elucidate the environmental behavior and } \\
\text { fate of hexahydro-1,3,5-trinitro-1,3,5-triazine (RDX), particulal'y as related to its transport and } \\
\text { chemical form in the food chain. To meet this goal, we needed to adapt and develop suitable } \\
\text { analytical methodology to fractionate and characterize both RDX and RDX-derived residues in soil } \\
\text { and plant matrices. Using the methodology that we developed, we assessed the chemical and } \\
\text { physical fate of RDX in soils and plants. In general, the plant availability and plant mobility of RDX is } \\
\text { substantially greater than that previously reported for TNT. }\end{array}$}} \\
\hline & & & \\
\hline \multirow{2}{*}{\multicolumn{2}{|c|}{$\begin{array}{l}\text { 20. DISTRIBUTION / AVAILABILITY OF ABSTRACT } \\
\square \text { UNCLASSIFIED/UNLIMITED Q SAME AS RPT. } \\
\text { 22a. NAME OF RESPEN'SIBLE INDIVIDUAL } \\
\text { MaIY Frances BOStIan }\end{array}$}} & \multicolumn{2}{|c|}{$\begin{array}{l}21 \text { ABSTRACT SECURITY CLASSIFICATION } \\
\text { UnClassified }\end{array}$} \\
\hline & & $\begin{array}{l}\text { 22b TELEPHONE (Include Area Code) } \\
301-663-7325\end{array}$ & $\begin{array}{l}\text { 22C. OFFICE SYMBOL } \\
\text { SGRIJ-RMI -S }\end{array}$ \\
\hline
\end{tabular}


Abstract (Cont.)

Hydroponic plant-culture systems were used to establish absorption capacity and to develop chemical-fate procedures. The relative order of root absorption or RDX was bush-bean $>$ blando brome $>$ wheat. Plant absorption was concentration-dependent, thus solid sorption processes should control the concentration of soil solution RDX and thus that fraction available for root uptake. The plant mobility of RDX was substantially greater than that previously observed for TNT. No significant mineralization or residue volatilization from shoot or root tissues was observed. Chemical fractionation and analyses of short-term hydroponically grown plants indicated that individual tissue chemical-class distribution patterns for RDX residues changed with duration of exposure. After 7 days, $74 \%$ of the total ether-extractable residues were RDX.

Studies with plants to maturity on RDX-amended soils showed RDX-derived metabolites to accumulate in all tissues. The relative order of tissue concentration was seed $>$ leaves $>$ stem $>$ leaves > root > pod. In bush bean, the tissue concentrations of RDX-derived residues at maturity were as high as 200 and $600 \mu \mathrm{g} / \mathrm{g}$ fresh weight for leaves and seed, respectively. In wheat and blando brome, leaf concentrations of RDX were as high as $550 \mu \mathrm{g} / \mathrm{g}$ fresh weight, while roots contained less than $45 \mu \mathrm{g} / \mathrm{g}$ fresh weight. Calculation of the percentage removal of RDX from the pots by single plants based on biomass production and tissue concentration indicate that 11 to $55 \%$ of the solid RDX was removed by bush bean and that 10 to $40 \%$ was removed in a single harvest of wheat and blando brome. These absorption rates make biomining a viable remediation option. In all cases, the form oi RDX isolated from tissues was greater than $50 \% \mathrm{RDX}$, the remainder being unidentified polar metabolites. 


\section{FOREWORD}

Opinions, interpretations, conclusions and recommendations are those of the author and are not necessarily endorsed by the U.S. Army.

$\frac{X}{1}$ Where copyrighted material is quoted, permission has been obtained to use such material.

$X$

Where material from documents designated for limited distribution is quoted. permission has been obtained to use the material.

$X$ Citations of commercial organizations and trade names in this report do not constitute an official Department of the Army endorsement or approval of the products or services of these organizations.

\footnotetext{
$x$ In conducting research using animals, the investigator ( $s$ ) adhered to the "Guide for the Care and Use of Laboratory Animals." prepared by the Committee on Care and Use of Laboratory Animals of the Institute of Laboratory Animal Resources. National Research Council (NIH Publication No. 86-23. Revised 1985.)
}

$X$ For the protection of human subjects, the investigator (s) have adhered to policies of applicable Foderal Law 45CFR46.

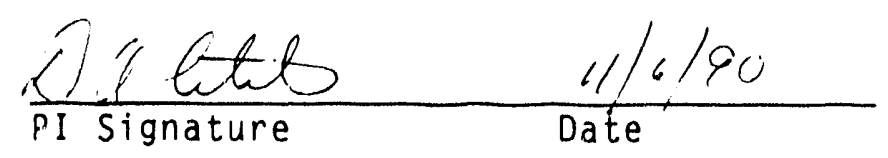




\section{EXECUTIVE SUMMARY}

The objective of these studies was to elucidate the environmental behavior and fate of hexahydro-1,3,5-trinitro-1,3,5-triazine (RDX), particularly as related to its environmental fate and behavior and its chemical form in the food chain. In general, the plant-availability and plant-mobility of RDX was substantially greater than that reported for related munitions such as TNT. The present studies clearly indicate that the environmental behavior of RDX is unique. $R D X$ is highly mobile and highly plant-available in the soiliplant system with concentration ratios (tissue concentration per unit weight/soil concentration per unit weight) ranging from 20 to 50 on a fresh-weight basis to 200 tn 500 on a tissue dry-weight basis. In addition, unlike many other environmental contaminants, RDX is accumulated in seeds of plants to levels approaching and in excess of those for leaves.

Mass-balance analyses of RDX amended to soils varying in mineralogy, cation exchange capacity (CEC), and organic-matter content gererally were good, ranging from $100 \%$ at 11 days to greater than $78 \%$ after 60 days of incubation. The extent of soil sorption of RDX after 60 days incubation was less than $2 \%$. Mass-balance deficits were only partially attributed to mineralization of $\mathrm{RDX}$ to $\mathrm{CO}_{2}$ and no volatile organic residues were detected. Chemical analysis of solvent extracts of soils incubated for 60 days showed only the parent compound to be present, with no indication of metabolite formation.

Hydroponic plant-culture systems were used to establish absorption capacity and to develop chemical-fate procedures. The relative order of root absorption of RDX was bush bean > blando brome $>$ wheat. Plant absorption was concentration dependent, thus soil sorption processes should control the concentration of soil solution RDX and thus that fraction available for root uptake. Analysis of kinetic constsnts for root absorption of RDX indicated a metabolically mediated absorption process. In 2-h uptake studies, approximately $50 \%$ of the accumulated residues were retained within the root, while in 7-day studies the quantity of RDX retained in the roots declined to less than $20 \%$ of that accumulated. Analysis of the rates of RDX mineralization and residue volatilization in hydroponically grown plants indicated no releases of volatiles from either shoot- or root-accumulated RDX residues. Some mineralization of accumu'ated $\mathrm{RDX}$ to ${ }^{14} \mathrm{CO}_{2}$ was observed for the root/rhizosphere.

Chemical frac'ionation and analyses of the F2 fractions of 1-and 7-day hydroponically grown plants indicated that greater than $98 \%$ of the activity contained in these fractions is RDX. Thirty to fifty percent of the activity associated with the more-polar fractions (F2, F3, and Aqbase) was from modified polar forms. Analysis of xylem exudates, which contain the RDX 
transported from root to shoot tissues, showed the mobile transport form to be RDX, with less than $2 \%$ being a more-polar form.

Studies with plants grown to maturity on RDX-amended soils showed RDX-derived metabolites to accumulate in all tissues. The relative order of tissue concentration was seed > leaves $\geq$ stem $>$ root $>$ pod. In bush bean, the tissuse concentrations for RDX-derived residues at maturity were as high as 200 and $600 \mu \mathrm{g} / \mathrm{g}$ fresh weight for leaves and seed, respectively. Roots contained less than $75 \mu \mathrm{g} / \mathrm{g}$ fresh weight. In wheat and blando brome, leaf concentrations of $\mathrm{RDX}$ were as high as $550 \mu \mathrm{g} / \mathrm{g}$ fresh weight while roots contained less than $45 \mu \mathrm{g} / \mathrm{g}$ fresh weight. Concentrations of RDX-derived residues in seed of the grasses were as high as those in the leaves. Calculations of the percentage removal of RDX from the pots by single plants based on biomass production and tissue concentrations indicate that 11 to $55 \%$ of the soil RDX was removed by bush bean and that 10 to $40 \%$ was removed in a single harvest of wheat and blando brome. These absorption rates make biomining a viable remediation option.

Tissue partitioning and chemical analyses indicated that RDX is the only nonpolar metabolite isolated from plants grown to maturity. RDX accounts for 6 to $53 \%$ of the accumulated residue activity in wheat and blando brome, 6 to $2 \%$ in bush bean leaves, and 2 to $10 \%$ of that in bean pods. Polar metabolites account for the vast majority of the remaining activity.

Total plant concentration is highly dependent on soil type, or soil available RDX concentrations. In all cases, plant uptake was inversely proportional to soil organic matter content for Burbank, Palouse and Cinebar soils. Overall, correlations of plant concentrations with either CEC or soil organic matter are not consistent. For bush bean and wheat, RDX accumulation correlates with CEC, while in blando brome RDX accumulation correlates best with organic matter content. While it is not possible to clearly define the soil factors influencing plant availability with only three soil types, the importance of CEC and organic-matter content is indicated, and can be used to establisin priorities for remediation. 


\section{CONTENTS}

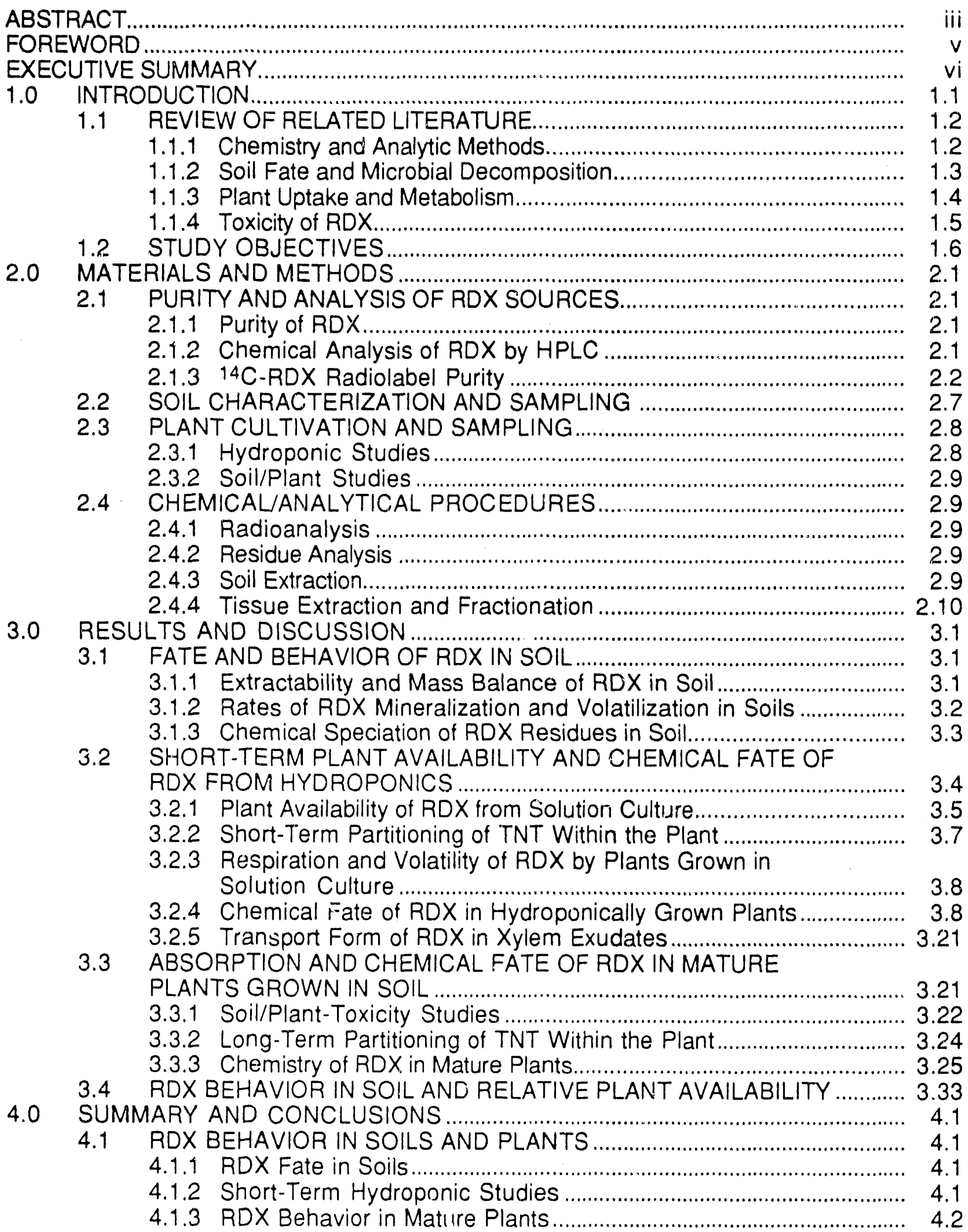




\section{CONTENTS (Continued)}

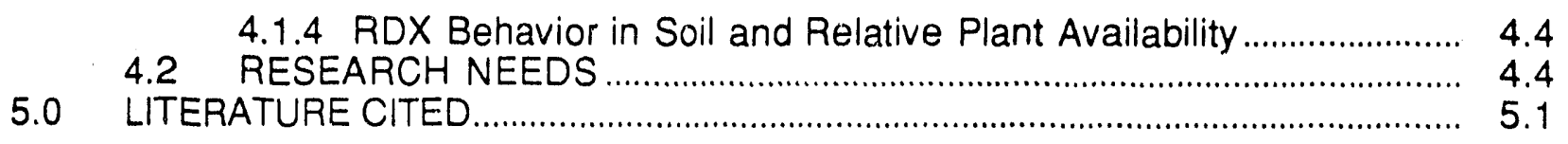




\section{FIGURES}

2.1. Radiochromatogram of RDX Before Purification .................................................. 2.3

2.2. Semi-Preparative HPLC Separation of ${ }^{14} \mathrm{C}$-RDX .................................................. 2.3

2.3. Co-injection of Peak 1 and Crystalline RDX …...................................................... 2.5

2.4. Radiochromatogram of the Purified RDX.................................................................. 2.5

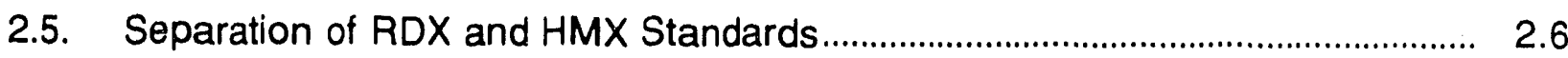

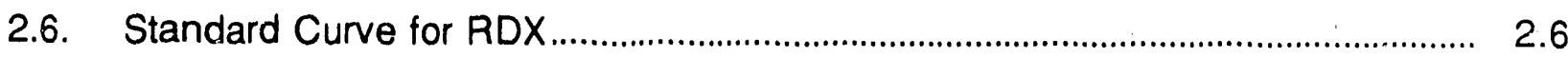

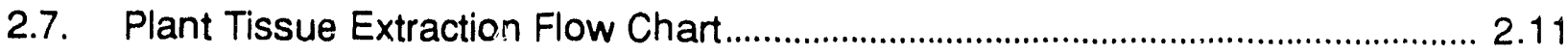

2.8. HPLC Chromatograms of a 3.66-ppm Solution of RDX and the Recovery of $3.6 \mathrm{ppm}$ RDX from Bush Bean Leaves ................................................ 2.15

2.9. Chromatograms of the F2 Fraction of Bush Beans Leaves Spiked

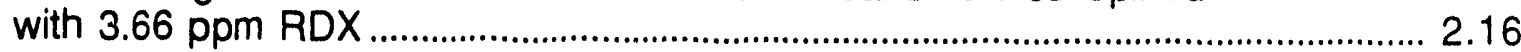

3.1. Radiochromatograph of Burbank Soil 60-Day Extract.......................................... 3.3

3.2. Radiochromatograph of Palouse Soil 60-Day Extract ......................................... 3.4

3.3. Radiochromatograph of Cinebar Soil 60-Day Extract.......................................... 3.4

3.4. Uptake Rates of Radiolabeled RDX by Roots of Bush Bean, Wheat, and Blando Brome from 1, 2.5, 5, and $10 \mathrm{ppm}$ RDX-Amended Nutrient Solutions.

3.5. Chromatograms of the F2 Fraction of Bush Bean Leaf, Stem, and Root Tissues

3.6. Radiochromatogram of the F2 Fraction of Bush Bean Root from a Plant Grown in Hydroponic Culture for 1 Day.

3.7. Radioctiromatogram of the F2 Fraction of Bush Bean Leaves from a Plant Grown in Hydroponic Culture for 1 Day 1 Day

3.8. Radiochromatogram of the F2 Fraction of Bush Bean Root from a Plant Grown in Hydroponic Culture for 7 Days.

3.9. Radiochromatogram of the F2 Fraction of Bush Bean Leaves from a Plant Grown in Hydroponic Culture for 7 Days.

3.10. Radiochromatogram of Bush Bean Exudates.

3.11. Radiochromatogram of Fraction F2 from Mature Bush Bean Leaf Tissue 


\section{FIGURES (Continued)}

3.12. Radiochromatogram of Fraction F2 from Mature Bush Bean Pod Tissue......

3.13. Radiochromatogram of Fraction F2 from Mature Blando Brome Shoot Tissue.

3.14. Radiochromatogram of Fraction F2 from a Mature Wheat Shoot Tissue

3.15. Plots of RDX Extractability Versus Soil Organic Matter Content and Cation-Exchange Capacity

3.16. Relationship of Soil Organic Matter and Cation-Exchange Capacity to Shoot RDX Concentrations in Bush Bean

3.17. Relationship of Soil Organic Matter and Cation-Exchange Capacity to Shoot RDX Concentrations in Wheat.

3.18. Relationship of Soil Organic Matter and Cation-Exchange Capacity to Shoot RDX Concentrations in Blando Brome 


\section{TABLES}

2.1. Selected Properties of Test Soils.

2.2. Fractionation of Acid-Hydrolyzed Leaf Tissue Spiked with $0.18 \mathrm{ppm}$ RDX by lon-Exchange Chromatography.....

2.3. Fractionation of RDX Using the Same Procedure as for TNT.

2.4. Radiolabel Distribution Among Various Chemical Fractions of Bush Bean Leaves Spiked with 3.66 ppm RDX.

3.1. Mass Balance of Soils Containing 60 ppm RDX.

3.2. Volatility and Mineralization of Soil-Amended RDX

3.3. Calculated $K_{s}$ and $V_{\max }$ Values from Double-Reciprocal Plots of RDX

3.4. Distribution of Radiocarbon in Plants Following a 2-h Exposure in Solution Culture at Various TNT Concentrations.

3.5. Distribution of Radio RDX in a Hydroponically Grown Bush Bean

Following a 72-h Exposure to a $10 \mathrm{ppm}$ Solution.

3.6. Quantity of RDX and Radiolabel in Hydroponic Solutions at the Beginning of the Study and at the Two Harvest Times.

3.7. Microgram RDX Equivalents in Chemical Fractions of Bush Bean

3.8. Percentage of Total Radioactivity, Based on Oxidation, in Chemical Fractions of Bush Bean After 1 Day....

3.9. Percentage of Total Radioactivity, Based on Oxidation, in Chemical Fractions of Bush Bean After 7 Days

3.10. Microgram RDX Equivalents in Chemical Fractions of Wheat.

3.11. Percentage of Radiolabel in Various Chemical Fractions of Wheat

3.12. Microgram RDX Equivalents in Chemical Fractions of Blando Brome 3.20

3.13. Percentage of Radiolabel in Various Chemical Fractions of Blando Brome

3.14. Average Fresh Weight of Wheat and Blando Brome Plants Grown for 60 Days in Soils Amended with $10 \mathrm{ppm}{ }^{14} \mathrm{C}-\mathrm{RDX}$ and in No:1Amended Control Soils

3.15. Average Fresh Wiainht of Bush Bean Plants Grown for 60 Days in Soils Amended with $10 \mathrm{ppm}{ }^{14} \mathrm{C}$-RDX and in Non-Amended Control Soils 
3.16. Specific Uptake for Plant Tissues of Bush Bean Grown for 60 Days in Soils Amended with $10 \mathrm{ppm}{ }^{14} \mathrm{C}-\mathrm{RDX}$ and for Chamber and Treatment Controls

3.17. Specific Uptake for Plant Tissues of Wheat and Blando Brome Grown for 60 Days in Soils Amended with $10 \mathrm{ppm}{ }^{14} \mathrm{C}$-RDX and for Chamber and Treatment Controls

3.18. Microgram RDX Equivalents in Chemical Fractions of Mature Bush Bean

3.19. Percentage of Total Radioactivity, Based on Oxidation, in Chemical Fractions of Mature Bush Bean Plants Grown on Three Soil Types

3.20. Microgram RDX Equivalents and Percentage of Total Radiolabel Contained in Various Chemical Fractions of Mature Bush Bean Pods

3.21. Microgram RDX Equivalents in Chemical Fractions of Mature Wheat and Blando Brome

3.22. Percentage of Total Radioactivity, Based on Oxidation, in Chemical Fractions of Mature Wheat and Blando Brome Grown in Three Soil Types. 


\subsection{INTRODUCTION}

Munition is materiel currently used as propellants or as explosive charges include trinitrotcluene (TNT) and hexahydro-1,3,5-trinitro-1,3,5-triazine (RDX), octahydro-1,3,5,7tetranitro-1,3,5,7-tetrazocine (HMX), and 2,4,6-trinitrophenylmethylinitramine (tetryl).

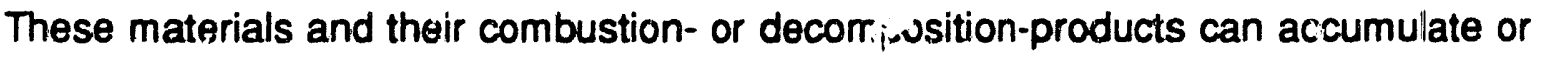
cycle in terrestrial environments, particularly at production and manufacturing facilities. An understanding of the persistence, bioavailability, and chemical fate of these contaminants is needed to avoid unwarranted environmental impacts and to establish decision moints with respect to remedial needs and approaches.

Federal regulations currisitily limit discharges of munitions components at the point of discharge to surface stream.s, where currently analyses are performed for TNT, RDX, HMX (a common impurity in RDX), and 2,4-dinitrotoluene (Jenkins et al., 1986; $\mathrm{Ba}$. 2 r et al., 1986). This monitoring and the current requirements to monitor drinking water sources in TNT, 2,4-DNT and 2,6-DNT (Belkin et al., 1985) establish the range of chemical species that would be of initial concern for understanding the environmental fate and behavior of munitions-based contaminants in soil and plant systems.

Munitions matoriel can enter the environment as a result of production and manufacturing activities and field usage and disposal (Small and Rosenblatt, 1974; Kitchens et al., 1978; Spanggord et al., 1983b; Ryon et al., 1984). Both the production of munitions materiel and their use for training purposes can lead to localized accumulations of parent munition compounds and stable decomposition products in terrestrial and aquatic environments. However, the presence of specific munitionsrelated components in the environment is not in itself indicative of the presence or severity of the impact. Organic cuntaminants or xenobiotics entering terrestrial and aquatic environments undergo chemical partitioning that is dependent on sorptive processes and water solubility. While these factors influence short-term accumulation and mobility, respectively, chemical stability and biologically mediated degradative processes greatly influence persistence and, therefore, accumulation.

Several abiotic and biotic processes are importarnt for assessing the relative longterm importance of munitions-related materiel released to the envircnment. These processes include the extent to which 1) the parent compound and related residues sorb 
to soil, thus limiting biological uptake and soil transport, 2) soil miciobes can degrade or modify the contaminant, 3) the parent compounds and their major decomposition products are accumulated by food-chain plants, and 4) plant-accumulated contaminants are metabolized and degraded. Studies of non-munitions-related organic xenobiotics clearly indicate that biotic systems are effective in degrading or detoxifying a variety of compound classes.

\subsection{Review of Related Literature}

Studies have been conducted on numerous munitions-based chemicals. The vast majority of these studies deal with development of analytical inethods and with characterization of parent compounds and decomposition products associated with waste streams, impoundments, and releases from production sites. Far fewer deal with environmental persistence, bioavailability, and metabolic detoxification. Except for the case of TNT, few stucies have addressed the chemical fate and behavior of parent compounds and residues at environmental concentrations. The following literature review discusses the status of TNT and RDX.

\subsubsection{Chemistry and Analytic Methods}

Effluent streams associated with TNT production processes have been characterized and showri to contain over 30 isomeric nitroaromatics and associated byproducts (Spanggord et al., 1982). Substantially less work has been performed with respect to RDX and HMX decomposition products. RDX is known to undergo hydrolysis in alkaline solution. The first step in ihe hydrolytic sequence is a proton abstraction with the concerted displacement of nitrate. Further hydrolysis results in the formation of nitrate, nitrous oxide, ammonia, formaldehyde, and formic acid (Hoffsonimer et al., 1977). Spanggord et al. (1930a) have determined that RDX, and most likely HMX, are subject to limited photochemical and soil microbial attack. Photolysis of RDX has been show to produce nitrate, ammonia, formaldehydo several unidentified nitroorganic compounds, and a significant proportion of nonextractable material. The nonextractable fraction is thought to consist largely of formic acid (Glover and Hoftsommer, 1979). It has been demonstrated that anaerobic microbial metabolism of RDX results in nitroso metabolites originating from nitro reductions, dimethylhydrazines, hydrazine, formaldehyde, and methanol (McCormick et al., 1981). 
A number of gas chromatography (GC) and gas chromatography/mass spectroscopy (GC/MS) methods have been developed for analyzing process waters. These methods permit identification and quantification of parent compounds, reaction by-products, and decomposition products (Spanggord et al., 1982, 1983a, 1983b; Belkin et al., 1985) of munitions. More recently, methods involving high-pressure liquid chromatography (HPLC) have been found to be suitable for the resolution and quantification of these major constituents (Jenkins et al., 1986; Bauer et al., 1986; Cataldo et al., 1990). Soil-extraction method's are available for the three parent munitions compounds (Jenkins and Grant, 1987; Cataldo et al., 1990). However, in plant tissues analysis of parent compounds and residues has been more troublesome (Palazzo and Leggett, 1986), because biological systems tend to alter the polarity of organic residues. The approach for TNT analysis described by Cataldo et al. (1990), based on adsorption chromatography, concurrently removes interfering pigments before analytical analysis and allows for the separation of polar from major nonpolar metabolites for mass-balance purposes.

\subsubsection{Soil Fate and Microbial Decomposition}

Although substantial soil-fate research has been performed for nitroguanidine (Spanggord et al., 1985), relatively few data are available for TNT. We are aware of no data relating to the relationship between soil characteristics (i.e., cation exchange capacity (CEC), pH, organic-matter content) and the extent of sorption and solubility. An understanding of these relationships is necessary to define limits of environmental mobility and plant availability.

Soil microbial studies, both in vivo and in vitro, indicate that TNT is subject to metabolic modification (McCormick et al., 1976). Kearney et al. (1983), using ${ }^{14} \mathrm{C}$-TNT, pre-UV irradiated and amended to soil, found respiratory losses of ${ }^{14} \mathrm{CO}_{2}$ to increase with time. Addition of microorganisms able to metabolize nitroaromatics resulted in a sharp increase in respiratory losses. Yang et al. (1983), using soil-isolated organisms, demonstrated a $90 \%$ reduction in extractable RDX over 3 days, with indications that the organisms were able to use the nitro groups as an alternate $N$ source. RDX has been shown to be degraded with a half-life of 7 days in a water/sediment system, but only after a several-week lag period (Sikka et al., 1980). The latter results indicated that ring opening occurred. In vitro anaerobic transformations have been reported for RDX and HMX and their acylated by-products SEX (1-acetyloctahydro-3,5,7-trinitro-1,3,5,7- 
tetrazocine) and TAX (1-acetyltiexahydro-3,5-dinitro-1,3,5-triazine) (Spanggord et al., $1982 ; 1983 \mathrm{~b}$ ), but rates of decomposition were substantially lower than for sediment systems. Nitroreductions, ring opening, and further reduction to methanol, formaldehyde, and hydrazines were the metabolic pathways implicateu by these studies. Although few soil studies have been performed, indications are that both anaerobic and aerobic biotransformations may occur.

\subsubsection{Plant Uptake and Metabolism}

Cataldo et al. (1990) recently evaluated the behavior and chemical fate of TNT in soils. Extensive transformation of TNT to 2-amino-4,6-dinitrotoluene and 4-amino2,6-dinitrotoluene was found to occur rapidly in the three different soils studied. Additionally, a unique volatile transformation product was isolated from one of the soils and partially characterized. This transformation product was most likely a transient intermediate in the formation of further nonvolatile transformation products. The amount of irreversibly bound TNT was found to increase in all soil types throughout the 2-month study, with the highest percentage of bound residue occurring in the soil with the highest organic-carbon content. Volatile organics were not evolved by the TNT-amended soils; however, the evolution of small amounts of ${ }^{14} \mathrm{CO}_{2}$ from the soils was verified. The mass balance of TNT in the three soils was acceptable throughout the 2-month study.

The literature contains very few data related to soil and plant fate, of TNT and to its bioavailability. In the 1970 s a substantial amount of research was performed on aquatic organisms, including algae and water plants. TNT has been found to be toxic to duckweed at levels in excess of $1 \mathrm{ppm}$ (Schott and Worthley, 1974), to inhibit freshwateralgae growth at 2 to $15 \mathrm{ppm}$ (Smock et al., 1976), and to inhibit the growth and metabolism of microorganisms (Klausmeier ef al., 1973; Nay et al., 1974). With the exception of Smock et al. (1976) and Schott and Worthley (1974), no chemistry was performed on either culture solutions or materials accumulated. The latter authors did note a conversion of TNT to 2,4-dinitrotoluene and 4 amino-2-nitrotoluene in their culture medium.

One higher-plant study was performed using hydroponically grown yellow nutsedge to assess the uptake, toxicity, and metabolic transformations of TNT (Palazzo and Leggett, 1986). This study showed shoot and, pirticularly, root growth to be inhibited at $5 \mathrm{ppm}$. Although not noted by the authors, these toxicity symptoms are 
characteristic of dinitroaniline herbicide damage. The latter would be expected based on the chemical structure of TNT, particularly the dinitrotoluenes. Chemical analysis showed $>90 \%$ of all tissue-extractable material to be 2 - and 4 -aminudinitrutoluene, with on ly a small amcunt of TNT being recovered. Since these species were not observed in the nutrient solutions, it is assumed that they are metabolic detoxificatiun products. No data for either RDX or HMX are available.

Cataldo et al. (1990) recently conducted detailed plant-fate studies of TNT. TNTderived ${ }^{14} \mathrm{C}$ was localized primarily in the roots, with a small amount of radiolabel being transported to the shoot and leaves. Examining the xylem exudate of bush beans grown in TNT-containing hydroponic solutions allowed for identifying the primary transport forms of TNT. Acid-hydrolyzeo' xylem exudate was found to contain 2-a.nino-4,6dintirotoluene and 4-amino-2,6-din :oluene, as well as an unidentified TNT metabolite. TNT is transported as these polar conjugates to the aerial portions of the plant, whitie it undergoes further metabolic alteration. Studies indicated that the polar TNT metabolites are sequestered within the plant and are not transpired as volatile organics of as ${ }^{14} \mathrm{CO}_{2}$. Chemical fractionation of plant tissues grown in TNT-containing hydroponic solution indicated that less than $12 \%$ of the incorporated radioiabel was due to eitiner TNT, 2 amino-4,6-dinitrotoluene, or 4-amino-2,6-dinitrotoluene. The majority of the radiolabel was found either in a polar ether-extractable fraction or in a more-polar non-etherextractable fraction. The preponderance of these previously unknown, highiy polar TNT transformation products was a major finding of this study. Continued research is needed to characterize these metabolites as well as the unknown metabolite implicated in the transport of TNT. Such research can be expected to lead to a better understanding of the toxicity associated with ingesting plant foliage grown on TNT-contaminated plots and of the possibility for food-chain transfer of TNT metabolites.

\subsubsection{Texicity of RDX}

The toxicity of RDX to a variety of organisms has been demonstrated. The oral LD50 for rats and mice has been estimated to be 100 and $59 \mathrm{mg} / \mathrm{kg}$, respectively. Toxicity toward rodents has led to the use of RDX as a rat poison (Merck Index, 1983). Additional toxicity tests haye shown detrimental reproductive effects, characterized by low birth weights and still births in rats administered RDX (Cholakis et al., 1980).

Several cases of toxicity in humans exposed to RDX at munitions manulacturing plants have been documented. Aliected workers suffered from unconsciousne'ss and 
epileptiform seizures after exposure to RDX-laden air (Kaplan et al., 1965). Although RDX is not mutagenic, its redustior, product, hexahyd $0-1,3,5$-trinitioso-1,3,5-triazine, has been used as an experimental tumorigen (Merck Index, 1983; Sax and Levis, 1989). This nitroso compound also has been identified as an RDX metabolite produced by anaerobic bacteria (McCormick et al., 1981).

\subsection{Study Objactives}

The major route of entry to the environment for nitro-substituted munitions materiels such as RDX is through discharges from production facilities and decommissioning activities. The objectives of the following studies were to develep necessary analyt:cal methodology and to assess the chemical fate and behavior of RDX in soil and plant systenis. Parlicular emphasis was placed on eiucidating 1) the chemical transformations that occur in soils and in plant tissues following accumulation and 2) the extent of bioaccumulation and thus the potential the impacts to the food web. 


\subsection{MATERIALS AND METHODS}

\subsection{Purity and Analysis of $\mathrm{BDX}$ Sources}

\subsubsection{Purity of $\mathrm{BDX}$}

Acetonitrile (ACN) solutions of RDX obtained from Battelle Columbus Division (West Jefferson, Ohio) were cloudy and contained insoluble material, even though the concentration of RDX in these solutions was well below the reported solubility of RDX in this solvent $\left(7.0 \mathrm{~g} / 100 \mathrm{~mL}\right.$ at $\left.30^{\circ} \mathrm{C}\right)$. Before initiating studies with $\mathrm{RDX}$, it was absolutely essential to have pure analyte. Chromogographic analysis of the bulk RDX revealed the absence of any HMX impurity. The insoluble material was most likely an insoluble filler material. Purification involved mixing $1.0 \mathrm{~g}$ crude RDX with $10 \mathrm{~mL}$ of acetone. The insoluble material was removed by filtering the mixture through 20.45 um Nylon 66 filter (Altech Associates, Deerfield, llinois). RDX in the filtrate was recrystallized from the acetone solution. To further purify the RDX, two more recrystallizations, one from acetone and one from $A C N$, were performed. The final RDX crystals were washed with hexane and allowed to dry. The purity of the recrystallized product was $>99.8 \%$.

\subsubsection{Chemical Analysis of $\mathrm{BDX}$ by HPLC}

The analytical chromatographic system consisted of a Waters Model 6COE system controller and pump, a Wisp Model 710B automatic injector, and a Waters Model $490 \mathrm{E}$. detector. Injected components $(20 \mu \mathrm{L})$ were separated on a Beckman Ultrasphere ODS column ( $24 \mathrm{~cm} \times 4.5 \mathrm{~mm} \mathrm{ID)}$ and detected by UV absorption at 243 $\mathrm{nm}$ with a detector sensitivity of 0.008 AUFS. The chromatographic conditions employed for the separation of RDX were a biphasic linear gradient delivered at a fiow rate of $1.0 \mathrm{~mL} / \mathrm{min}$. The mobile phase was in ally programmed from 20 to $60 \% \mathrm{ACN}$ over a period of $20 \mathrm{~min}$. The solvent ramp was continued from 60 to $100 \% \mathrm{ACN}$ over $10 \mathrm{~min}$ and held at $100 \% \mathrm{ACN}$ for an additional $10 \mathrm{~min}$. The final crystalline RDX product exhibited one peak when detected at 254,243 , or $210 \mathrm{~nm}$. The same chromatographic conditions were used for all soil- and plant-extract samples.

A biphasic gradient was chosen to offer the highest probability of resolving the broadest range of RDX transformation products. An initial shaliow gradient would allow for adequate resolution of the various nitroso transformation products that have 
been reported by previous investigators (McCormick et al., 1981). Additionally, a slow initial gradient should allow for the resolution of $\mathrm{HMX}$ (an impurity commonly found in RDX) from RDX. Since RDX transformation products less polar than the parent have not been described in the literature, the rapid gradient ramp from 60 to $100 \%$ acetonitrile wouid elute nonpolar transformation products, should they exist, within a limited range of the chromatogram. Radiochromatographic detection was used extensively for unambiguous identification of transformation products arising from TNT. During selected chromatographic runs, the column eluate was collected in $0.5-\mathrm{mL}$ increments for a tutal of $30 \mathrm{~min}$. Each fraction was assayed for radioactivity by liquid-scintillation spectrometry. Radiochromatograms were generated by plotting the disintegrations per minute (dpm) as a function of retention time in each successive aliquot.

\section{$2.1 .3{ }^{14} \mathrm{C}-\mathrm{BD} \times$ Radiolabel Purity}

Uniformly ring-labeled ${ }^{14} \mathrm{C}$-RDX (specific activity of $25.3 \mathrm{mCi} / \mathrm{mmole}$ ) was obtained from Sigma Chemical Company (St. Louis, Missouri). Initial studies with the radiolabeled RDX examined its purity by radiochromatography under the chromatographic conditions given above. Figure 2.1 shows a radiochromatogram resulting from an injection of radiolabeled RDX. Under the chromatographic conditions used, RDX had a retention time of $17.64 \mathrm{~min}$. As evidenced by the appearance of radiolabeled constituents both before and after the RDX peak, the ${ }^{14} \mathrm{C}$ RDX was not pure. By comparing the radioactivity contained in the RDX peak to the total amount of radiolabel eluted, a purity of $90.5 \%$ was calculated. Because this purity was not sufficient for metabolic studies, further purification of the radiolabeled RDX was indicated.

Semi-preparative high-performance liquid chromatography was used to purify the radiolabeled RDX. The chromatographic system consisted of a Waters Model M6000A pump connected to a Waters U6K injector. The column was a Beckman Ultrasphere ODS (25 cm $\times 10 \mathrm{~mm}$ ID), and detection was accomplished by monitoring the UV absorption at $254 \mathrm{~nm}$ (Schoeffel GM 770 detector). The $30 \% \mathrm{ACN}$ to $70 \%$ $\mathrm{H}_{2} \mathrm{O}$ isocratic mobile phase was delivered at a flow rate of $5.0 \mathrm{~mL} / \mathrm{min}$. Crystalline RDX (purified as described above) gave a retention time of $17.60 \mathrm{~min}$ under these conditions. A representative chromatogram of the radiolabeled RDX is shown in Figure 2.2. This chromatogram resulted from a $140-\mu \mathrm{L}$ injection of the radiolabeled RDX. Injections of more than $140 \mu \mathrm{L}$ resulted in column overloading with the 


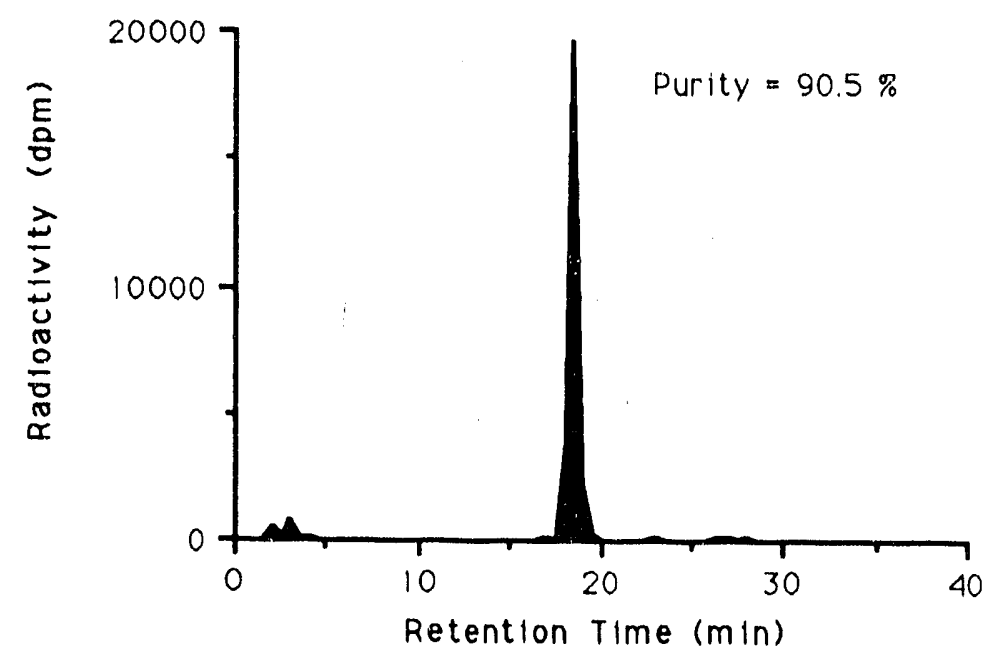

FIGURE 2.1. RADIOCHROMATOGRAM OF RDX BEFORE PURIFICATION

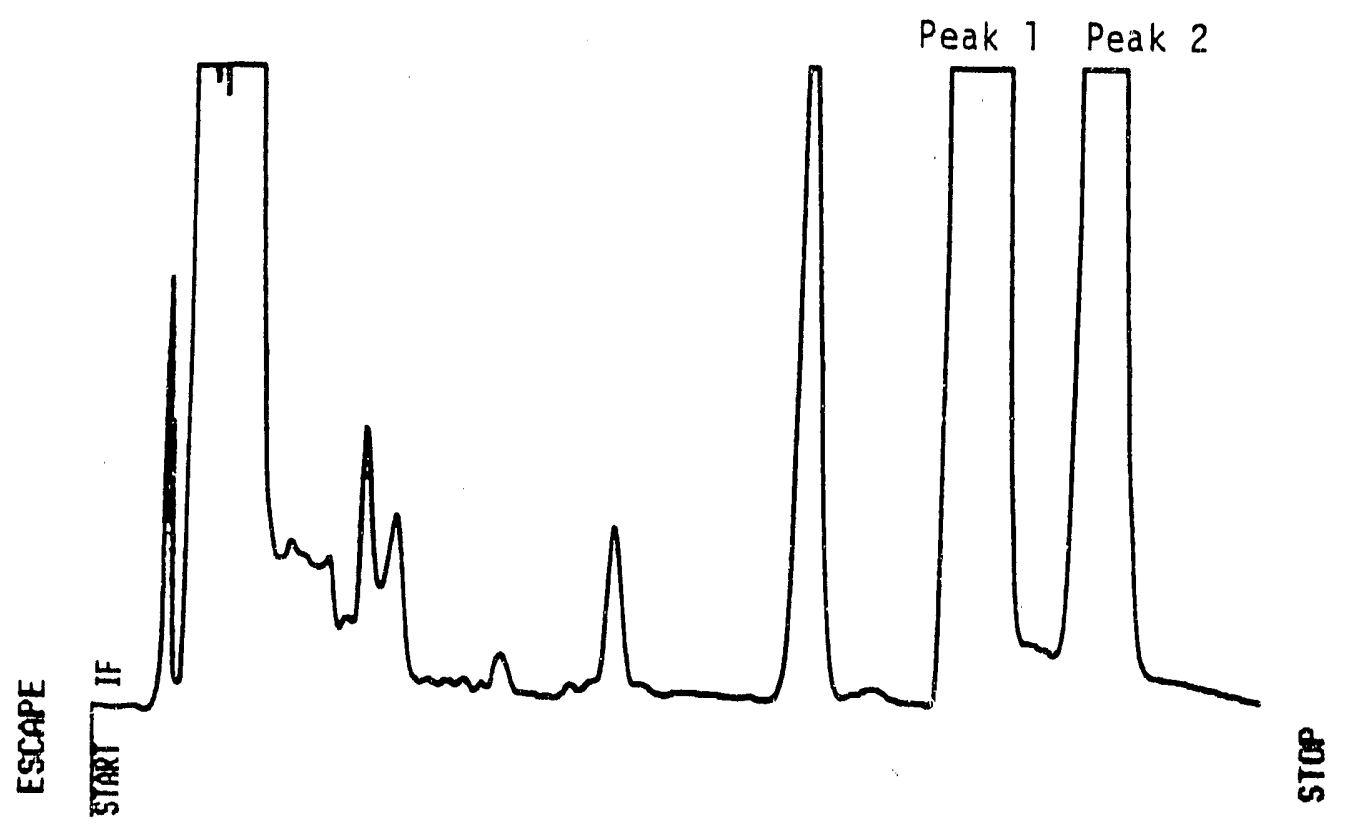

EIGURE 22. SEMI-PREPARATIVE HPLC SEPARATION OF ${ }^{14} \mathrm{C}-\mathrm{RDX}$ 
concomitant loss of the resolution necessary to discriminate the adjacent contaminant peaks. The column eluant corresponding to Peak 1 (retention time of $17.60 \mathrm{~min}$ ) and Peak 2 (retention time of $20.1 \mathrm{~min}$ ) was collected during a total of 22 chromatographic runs.

Aliquots of the separated semi-preparative materials were compared with crystalline RDX under analytical-chromatographic conditions to determine whether Peak 1 or Peak 2 corresponded to ${ }^{14} \mathrm{C}$-RDX. Peak 1 in Figure 2.2 co-eluted with crystalline RDX on the analytical reversed-phase column. The chromatogram resulting from the co-injection of equal amounts of crystalline RDX and Peak 1 material is shown in Figure 2.3. The appearance of only one peak verifies the identity of Peak 1 as ${ }^{14} \mathrm{C}$-RDX. Co-injection of crystalline RDX and Peak 2 resulted in two peaks on the analytical system. This experiment served to further verify the identity of Peak 1 as ${ }^{14} \mathrm{C}$-RDX.

$\mathrm{ACN}$ was removed from the Peak 1 eluant by a stream of dry nitrogen. As the $A C N$ was removed, ${ }^{14} \mathrm{C}$-RDX precipitated from solution. The water solvent was then frozen and sublimed by lyophilization, leaving crystalline ${ }^{14} \mathrm{C}-\mathrm{RDX}$ on the flask walls. The RDX was dissolved in acetone and examined by HPLC and liquid-scintillation spectrometry. Approximately $2.90 \mathrm{mCi}$ of RDX was purified by this proceduru. The radiochromatogram presented in Figure 2.4 demonstrates that the purified ${ }^{14} \mathrm{C}$-RDX was $99.93 \%$ pure. This purity was judged appropriate for metabolic studies.

Since RDX often contains the explosive HMX as an impurity, it was essential to demonstrate that the separation conditions were capable of resolving RDX from HMX. Figure 2.5 presents a chromatogram illustrating the separation of RDX and HMX standards. As shown in this figure, RDX and HMX were readily separated under the chromatographic conditions used in this study. It follows that the recrystallized bulk RDX and purified ${ }^{14} \mathrm{C}$-RDX were free from any HMX impurity.

To further characterize the purified radiolabel, we constructed a standard curve for RDX, presented in Figure 2.6. By comparing the ${ }^{14} \mathrm{C}-\mathrm{RDX}$ peak area (detected at $243 \mathrm{~nm}$ ) in Figure 2.4 with the standard curve, we caic!lated that a total of $46.51 \mathrm{mg}$ of radiolabeled RDX had been purified. Further calculations indicated that the purified radiolabel had a specific activity of $13.68 \mathrm{mCi} / \mathrm{mmole}$. 


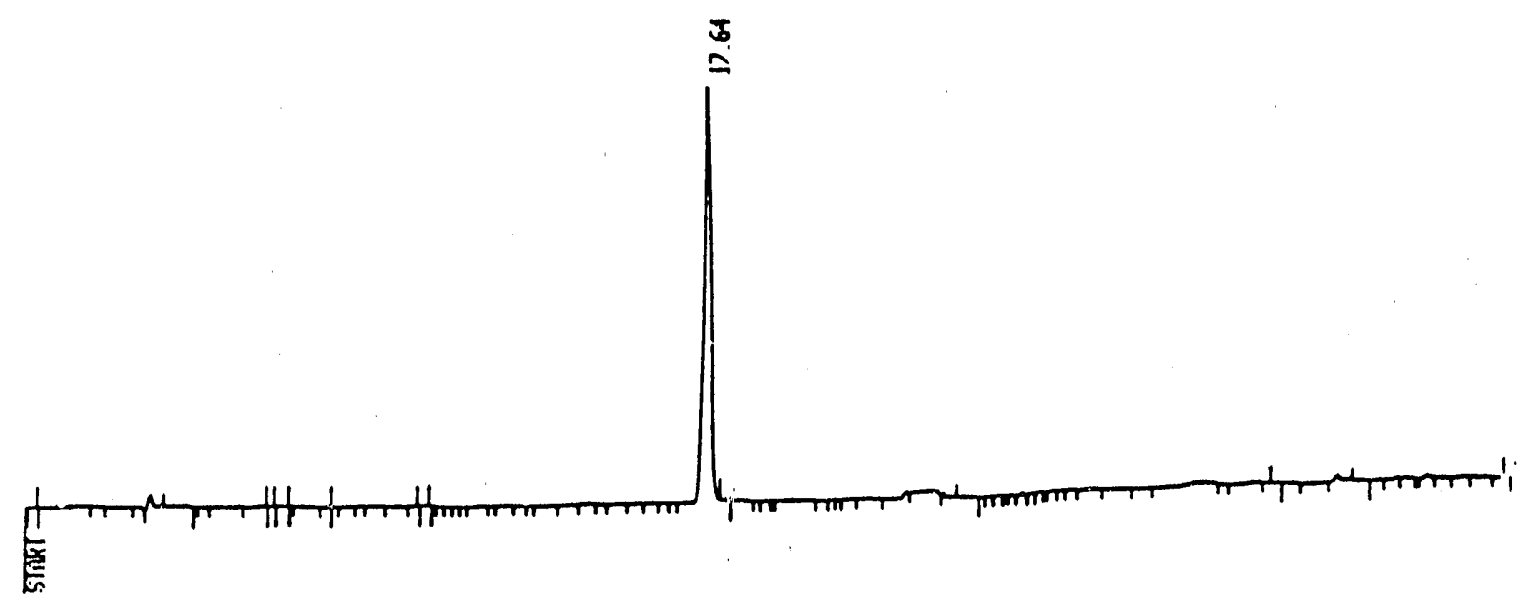

FIGURE 2.3. CO-INJECTION OF PEAK 1 AND CRYSTALLINE RDX

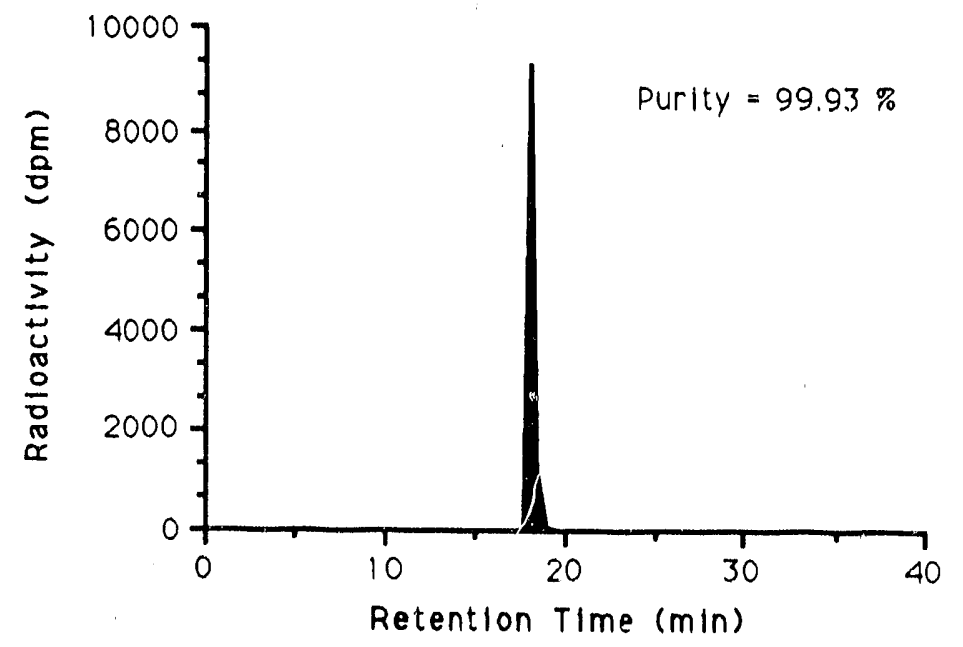

EIGURE24. RADIOCHROMATOGRAM OF THE PURIFIED RDX 


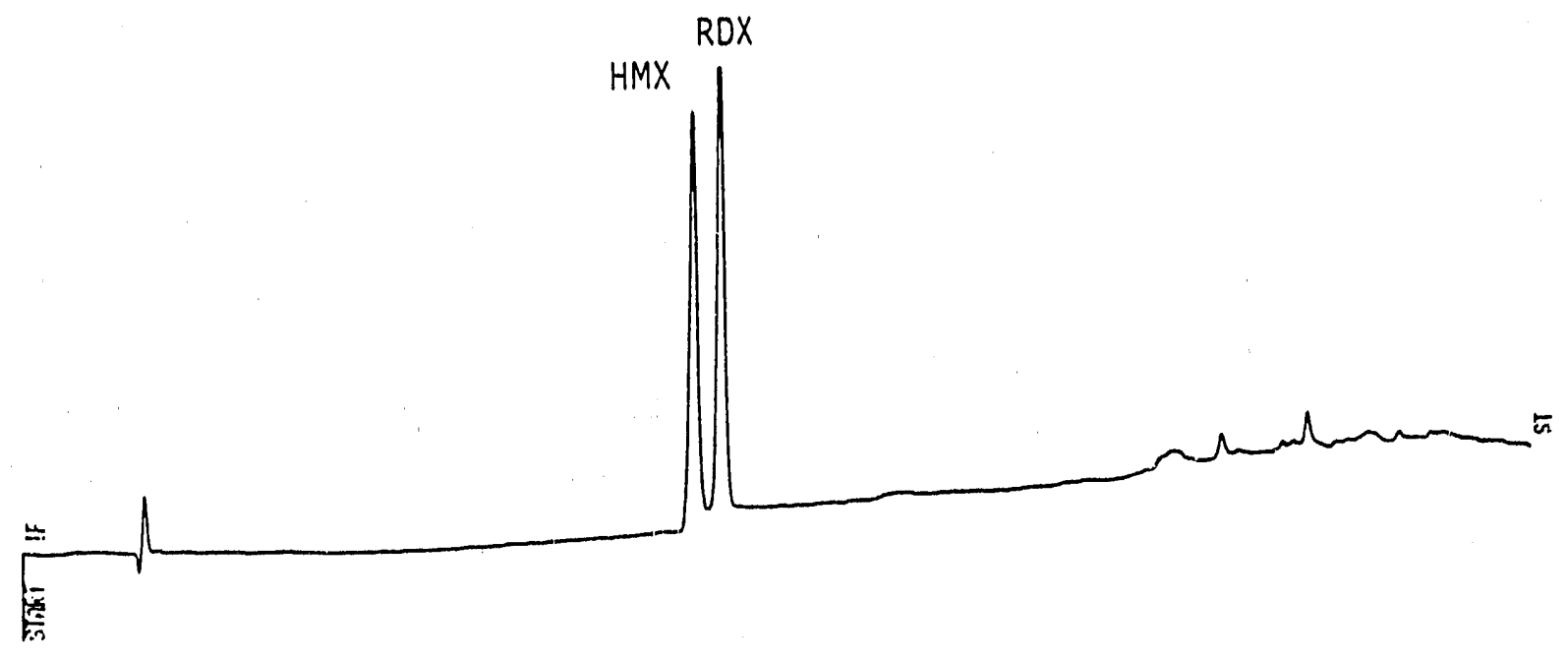

EIGURE2.5. SEPARATION OF RDX AND HMX STANDARDS

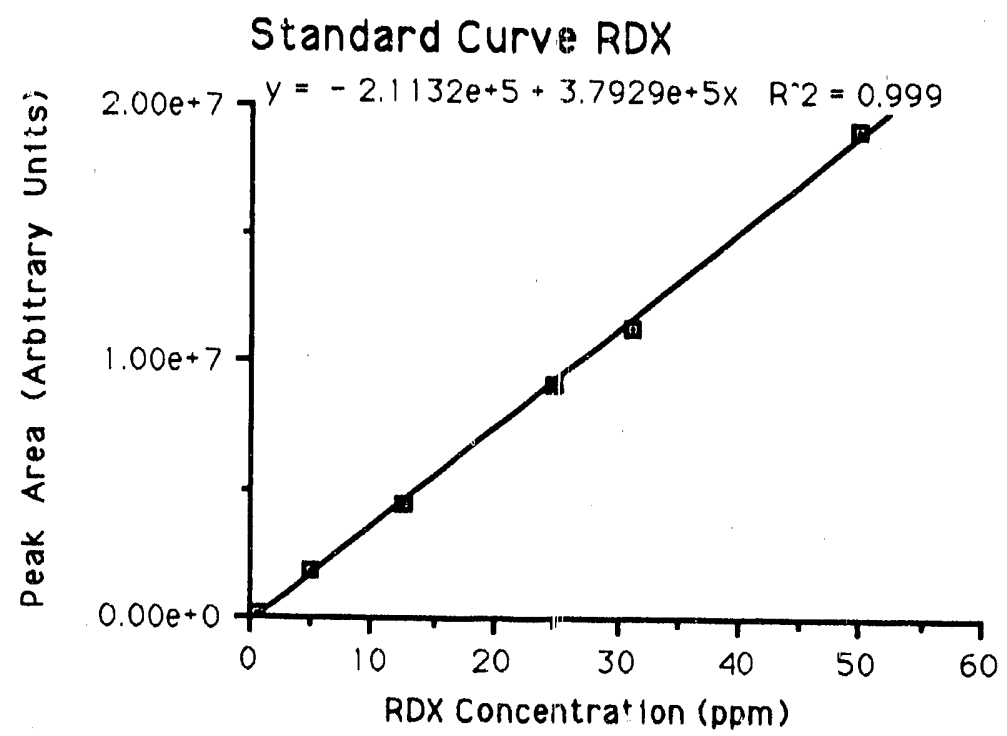

EIGURE2.6. STANDARD CURVE FOR RDX 


\subsection{Soil Characterization and Sampling}

The chemical and physical characteristics of soils used in these studies are tabulated in Table 2.1. Pallouse soil, representing a typical Washington-state agricultural soil, was used for all studies. Palouse is a silt-lokim, mixed mesic Pachic Ultic Haploxero!l. The sample was collected at Pullmair, Washington; and consisted of the Ap horizon. This soil is $77 \%$ silt and $21 \%$ clay, contains $1.7 \%$ organic matter, and has a CEC of $23.8 \mathrm{meq} / 100 \mathrm{~g}$ and a pH of 5.6. Burbank is a sandy loam (sandy, skeletal, mixed xeric Torriorthent) and is representative of the desert areas of Washington, Oregon, and Idaho. The sample was collected on the Hanford Site, near Richland, Washington, and consisted of the Ap horizon. This soil is $51 \%$ silt, $4 \%$ clay, and $45 \%$ sand, coritains $0.5 \%$ organic matter, and has a CEC of $5.5 \mathrm{meq} / 100 \mathrm{~g}$ and a $\mathrm{pH}$ of 5.6 . Cinebar, a clay loam, has $51 \%$ silt, $13 \%$ clay, and $35 \%$ sand, contains $7.2 \%$ organic matter, and has a CEC of $38.2 \mathrm{meq} / 100 \mathrm{~g}$ and a pH of 5.6. Cinebar is a Washington forest soil from the Cascade Mountain Range.

\section{IABLE2.1. SELECTED PROPERTIES OF TEST SOILS}

\begin{tabular}{lccc}
\hline Soil Property & $\begin{array}{c}\text { Burbark } \\
\text { Sandy Loam }\end{array}$ & $\begin{array}{c}\text { Palouse } \\
\text { Silt Loam }\end{array}$ & $\begin{array}{c}\text { Cinebar } \\
\text { Clay Loam }\end{array}$ \\
\hline \% Sand & 45.1 & 1.1 & \\
$\%$ Silt & 51.4 & 77.5 & 35.2 \\
$\%$ Clay & 4.0 & 21.4 & 51.4 \\
$\%$ Ash & 98.0 & 93.8 & 13.4 \\
PH (100\% field sapacity) & 7.4 & 5.4 & nd (a) \\
Organic carbon $(\%)$ & 0.5 & 1.7 & 5.6 \\
Sulfur $(\%)$ & 0.053 & 0.043 & 7.2 \\
Nitrogen $(\%)$ & 0.061 & 0.16 & nd \\
Total P $(\mu \mathrm{g} / \mathrm{g})$ & 2400 & 3770 & 0.44 \\
Phosphate-P $(\mu \mathrm{g} / \mathrm{g})$ & 4.8 & 5.8 & 3400 \\
Carbonate/Bicarbonate $(\%)$ & $<0.1$ & $<0.1$ & 26 \\
Ammonium- $(\mu \mathrm{g} / \mathrm{g})$ & 6.1 & 18.3 & $<0.1$ \\
CEC (meq/100 g) & 5.5 & 23.8 & 15 \\
& & & 38.2 \\
\hline
\end{tabular}

(a) nd = not determined. 
For soil experiments, solutions containing appropriate proportions of labeled and/or uniabeled RDX were prepared in $2.0 \mathrm{~mL}$ of methanol and amended with quantities of air-dried soil corresponding to oven-dry weights of $400 \mathrm{~g}$ to give final concentrations of $60 \mathrm{ppm}$ RDX containing 10 o: $20 \mu \mathrm{Ci}$ of labeled RDX. Soils were brought to 0.66 of field capacity immediately before amendment and were maintained at this moisture level throughout the experiment. Initial sampling was performed to assure both mixing efficiency and activity levels. Soils were maintained in a growth-chamber environment that simulated the luminous intensity and spectral dispersion of sunlight $\left(500 \mu \mathrm{Em}^{-2} \mathrm{sec}^{-1}\right)$ during the 16-h daily light cycle.

\subsection{Plant Cultivation and Sampling}

The chemical fate of RDX in plants was evaluated using bush beans (Phaseolus vulgaris), wheat (Triticum aestivum), and blando brome (Bromus mollis). All plants used for either hydroponic or soil studies were grown from seed. All plants were maintained in controlled-environment chambers with a 16/8-h light cycle [500 $\mu \mathrm{Em}^{-2} \mathrm{sec}^{-1}$, photosynthetical active radiation (PAR) at leaf surface], a day/night temperature of $26 / 22^{\circ} \mathrm{C}$, and $50 \%$ relative humidity.

\subsubsection{Hydroponic Studies}

Plants were grown for 18 to 26 days on hydroponic nutrient solutions as described previously (Cataldo et al., 1978), after which solutions were amended with 1 to $25 \mathrm{ppm}$ RDX containing $5 \mu \mathrm{Ci}$ of radiolabeled RDX jer $500 \mathrm{~mL}$. These solutions were filter-sterilized and placed in autoclaved $500-\mathrm{mL}$ beakers to minimize bacterial contamination, which could promote transformation of RDX. Plants were placed in these solutions and maintained in a growth chamber until harvested. The beakers were jacketed in an opaque sheath to protect the roots from light and to minimize the photolysis of RDX. Solutions were analyzed by HPLC and liquid-scintillation spectrometry at specified intervals. At harvest, plants were removed from the hydroponic solutions and the roots were rinsed with $0.1 \mathrm{M} \mathrm{CaCl}_{2}$ followed by a rinse in methanol: water $(80 \%: 20 \%)$. Plants were then separated into component tissues (roots, stems, leaves) as described; the tissues were minced, thoroughly mixed, analyzed for radiocarbon, and stored at $-80^{\circ} \mathrm{C}$ until chemical analysis. 


\subsubsection{Soil/Plant Studies}

Soil studies were conducted with both unlabeled and radiolabeled RDX. Soils were uriformly mixed to the roncentration noted, and plants were grown to maturity. Shoot tissues were harvested and the roots washed free of adhering soil. All tissues were assayed for radioactivity and analyzed for RDX and residues.

\subsection{Chemical/Analytical Procedures}

\subsubsection{Badioanalyses}

Soils and plant tissues were oxidized by total combustion in a Packard Model 306 oxidizer (Packard Instrumient Co., Downers Grove, llinois) to determine the amount of radiocarbon associated with each sample. Combusted samples and liquid samples were counted using a Beckman 9800 Liquid Scintillation Spectrometer (Beckman Instruments, Downers Grove, Illinois) with appropriaie quench correction.

\subsubsection{Residue Analysis}

Soil and plant-tissue extracts were analyzed by reversed-phase HPLC with detection at $243 \mathrm{~nm}$ as described above (Section 2.1.2).

\subsubsection{Soil Extraction}

Soils (400 g oven-dry weight) were amended with a total of $60 \mathrm{ppm}$ RDX containing $10 \mu \mathrm{Ci}$ radiolabeled RDX. The three soil types, Burbank, Palouse, and Cinebar, were the same as those Cataldo et al. (1990) used for studies with TNT. Soils were brought to 0.66 of field capacity before amending them with RDX. Three 10-g subsamples of each soil were taken immediately after amendment and at 11, 30, and 60 days post-amendment. Soil samples were subjected to Soxhlet extraction with 200 $\mathrm{mL}$ of acetonitrile for $48 \mathrm{~h}$. The soil extracts were filtered through a $0.45-\mu \mathrm{m}$ Nylon-66 filter before reducing the volume to approximately $20 \mathrm{~mL}$ by rotary evaporation. The concentrated extract was filtered a second time through a Nylon-66 filter before the volume was adjusted to $25.0 \mathrm{~mL}$. To determine the extraction efficiency, a 100- $\mu \mathrm{L}$ aliquot of the final extract was counted by liquid-scintillation spectrometry and compared to the amount of radiolabel originally added to the soil. A $20-\mu \mathrm{L}$ portion of the final extract was analyzed by HPLC. The HPLC insirumentation and 
chromatographic conditions were described in Section 2.1.2. Extracted soils were dried in an oven $\left(105^{\circ} \mathrm{C}\right)$ overnight to provide an accurate oven-dry weight and were oxidized to determine the percentage of irreversibly bound residue that could not be removed by extraction with acetonitrile. Oxidations weris performed on a Packard Model 306 oxidizer (Packard Instrument Co., Downers Grove, lllinois).

\subsubsection{Iissue Extraction and Fractionation}

Two fractionation schemes were developed for analyzing RDX in plant tissues. The initial step of both methods was solvent extraction of RDX from acid-hydrolyzed plant tissue. The methods differed only in the fractionation of the extracted plant components. It was necessary to further fractionate the organic extracts to remove plant pigments, which would interfere with subsequent HPLC analysis. One method was based on fractionation using a strong-cation exchange resin, whereas the other fractionation was based on Florisil chromatography. Figure 2.7 presents a complete flow chart for the latter method, which was eventually used for the tissue fractionations contained in this report. The initial solvent extraction of plant leaves (up to the Florisil chromatography step) was identical for both methods.

Extraction and fractionation studies with RDX examined acid-hydrolyzed bush bean leaves spiked with radiolabeled RDX. Tissue ( $1.00 \mathrm{~g}$ fresh weight) was homogenized for $2.5 \mathrm{~min}$ in a Sorvall Omni-Mixer (Newtown, Conneticut) with approximately $10.0 \mathrm{~mL}$ of $1-\mathrm{M} \mathrm{HCl}$ and was then spiked with a total of $0.18 \mathrm{ppm}$ RDX containing 26,959 dpm. The spiked tissue was subjected to acid hydrolysis for $1 \mathrm{~h}$ at $100^{\circ} \mathrm{C}$. Neutral and acidic compounds were extracted with $10.0 \mathrm{~mL}$ of methylene chloride. The solutions remaining after extraction are refelred to as the $\mathrm{HCl}$ and the $\mathrm{MeCl}_{2} \mathrm{AN}$-fractions. The aqueous $\mathrm{HCl}$ layer was then made basic by the addition of $4.0 \mathrm{~mL}$ of $4 \mathrm{M} \mathrm{NH}_{4} \mathrm{OH}$ and was extracted with a second $10.0-\mathrm{mL}$ aliquot of methylene chloride. The solutions remaining after the second extraction with methylene chioride were designated the Aq-base and the $\mathrm{MeCl}_{2}$-base fractions. A $100-\mu \mathrm{L}$ aliquot of each fraction was sampled and counted by liquid scintillation spectrometry. The organic fractions were next pooled, the solvent evaporated to dryness under a stream of dry nitrogen, and the residue reconstituted with $2.0 \mathrm{~mL}$ of appropriate solvent for further separation.

Initially, separations were performed on a strong cation-exchange resin (Supelco, Bellefonte, Pennsylvania). A methodology based on the LC-SCX resin was 


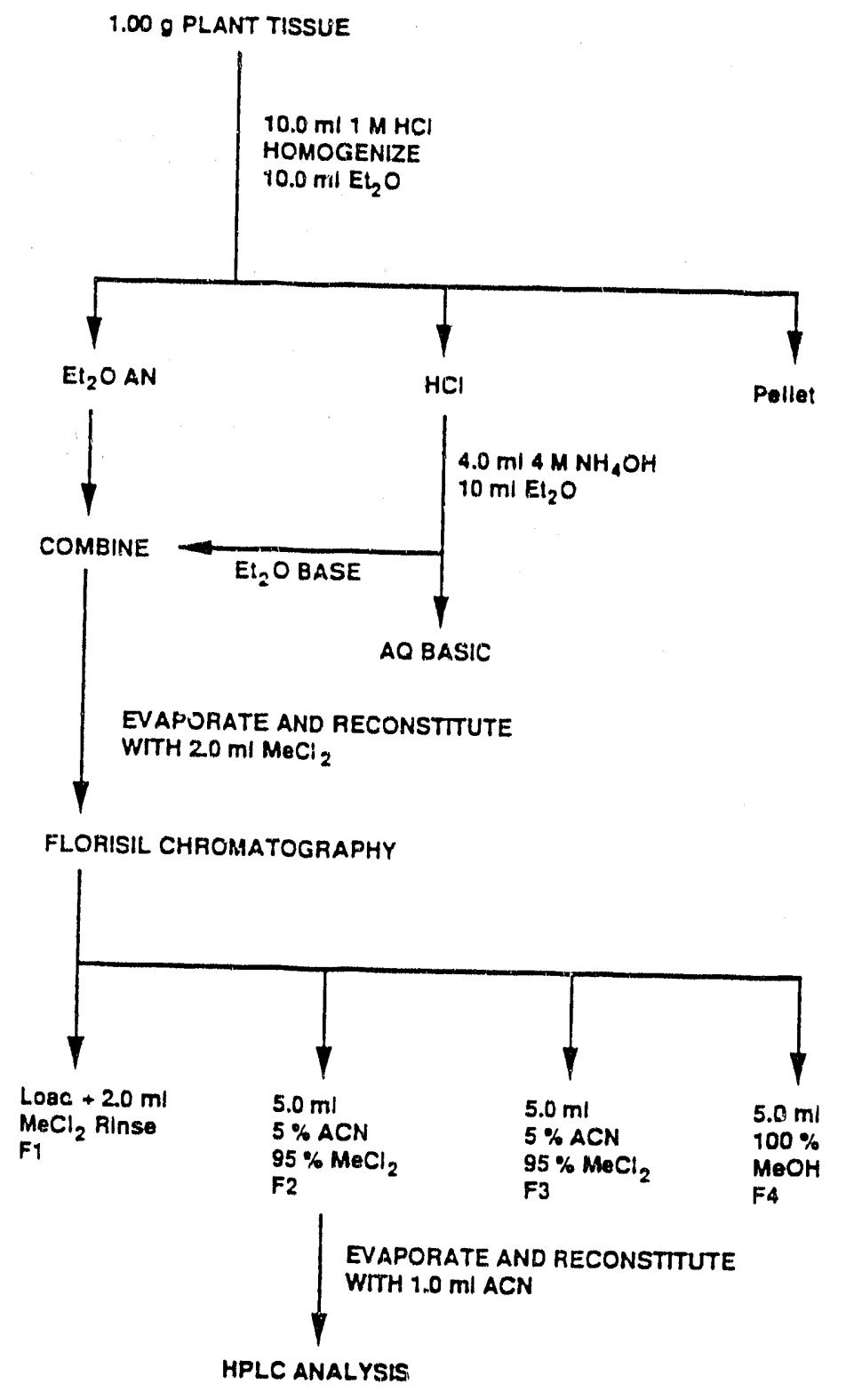

EIGURE 27. PLANT TISSUE EXTRACTION FLOW CHART

chosen because investigators (McCormick et al., 1981) have reported microbial transformation of RDX to hydrazine and dimethyl hydrazine metabolites. Because it is neutrally charged, RDX would be expected to pass through the SCX columin unretained, while the hydrazine and dimethyl hydrazine components would be strongly retained by the column. The SCX column thus offered a convenient means by which to 
separate these metabolites from the parent compound. Four different mobile phases of various solvent strengths were used to elute components from the resin, resulting in four fractions (F1-F4). In order of application to the resin, the solvents were methylene chloride, acetonitrile, water, and methanol. After elution, the four fractions were analyzed by liquid-scintillation spectrometry. The results of this triplicate-spike experiment are shown in Table 2.2. RDX was found to elute in fraction F1, as might be expected from a neutral species. Liquid scintillation performed on the spent resin showed that RDX was not adsorbed. It was pos' ble to further analyze fraction F1 to quantify RDX by HPLC, since this fraction was relatively free of interfering plant pigments.

The second method was based on variation of the procedure previously used to isolate TNT and TNT metabolites from the plant-tissue matrix (Cataldo et al., 1990). Radiolabeled RDX (26,959 dpin) was applied direcily to a Florisil chromatography column (Sep-Pak, Waters Associates, Milford, Massachusetts). The mobile phases that were successively applied to the column were methylene chloride, two separate applications of methylene chloride: ethyl acetate (92:8), and methanol. The distribution of radiolabel resulting from this factionation is shown in Table 2.3. As was found for TNT, most of the radiolabel eluted in fraction F2. From the previous work, we knew that fraction F2 was relatively free of plant pigments and therefore suitable for HPLC analysis. However, the use of this solvent system for isolating of RDX caused unacceptable carry-over of RDX radiolabel into fraction F3 (Table 2.3).

IABLE2.2. FRACTIONATION OF ACID-HYDROLYZED LEAF TISSUE SPIKED WITH 0.18 pPM RDX BY ION-EXCHANGE CHROMATOGRAPHY

\begin{tabular}{cccc}
\hline Chemical Fraction & $\mathrm{dpm}$ & Volume & \% Total Radiolabel \\
\hline F1 & 934 & 2.53 & 88 \\
F2 & 25 & 3.54 & 3 \\
F3 & 0 & 4.49 & 0 \\
F4 & 0 & 4.07 & 0 \\
resin & 0 & & 0 \\
\hline
\end{tabular}


IABLE23. FRACTIONATION OF RDX USING THE SAME PROCEDURE AS FOR TNT (Cataldo et al. 1990)

\begin{tabular}{cccc}
\hline Chemical Fraction & $\mathrm{dpm}$ & Volume & \% Total Radiolabel \\
\hline F1 & 22 & 3.68 & 3 \\
F2 & 414 & 5.01 & 77 \\
F3 & 94 & 5.35 & 19 \\
F4 & 12 & 5.70 & 3 \\
\hline
\end{tabular}

We sought to further refine the solvent composition to allow for elution of all the $\mathrm{RDX}$ within fraction F2 while retaining the plant pigments. These efforts resulted in the scherne summarized in Figure 2.7. We tested the suitability of this scheme by performing a triplicate-spike experiment with bush bean leaves. Three tissue samples ( $1.00 \mathrm{~g}$ ) were spiked with $3.66 \mathrm{ppm}$ RDX (containing $27,525 \mathrm{dpm}$ ) on a fresh-weight basis and fractionated in accordance with Figure 2.7 except that extraction was performed with methylene chloride. Diethyl ether was later substituted to allow for extraction of RDX-metabolites of higher polarity. Studies comparing the extraction efficiency of diethyl ether and methylene chloride revealed comparable recoveries of RDX (over $97.5 \%$ ) for both solvents. The tissues were acid-hydrolyzed and extracted with methylene chloride as described above. The pooled organic extracts were evaporated with a stream of dry nitrogen and the residue was reconstituted with $2.0 \mathrm{~mL}$ of methylene chloride and then fractionated on Florisil adsorbent. The first Florisil fraction ( $F 1$ ) was the eluant resulting frc $m$ sample loading followed by a 2.0- $\mathrm{mL}$ aliquot of methylene chloride used to rinse the sample vial. The second and third fractions (F2 and F3) were eluted from the column with separate $5.0-\mathrm{mL}$ aliquots of 95:5 methylene chloride:acetonitrile (ACN). The last fraction (F4) was eluted with 5.0 $\mathrm{mL}$ of $100 \%$ methanol in an attempt to strip the adsorbent of the remaining material. Aliquots $(100 \mu \mathrm{L})$ were taken from the Florisil fractions for liquid-scintillation spectrometry. Fraction F2, which was found to contain RDX, was evaporated to dryness with a stream of dry nitrogen, reconstituted with $1.0 \mathrm{~mL}$ of acetonitrile, and analyzed by HPLC. 
Table 2.4 presents the distribution of radiolabel among the chemical fractions generated by Florisil fractionation. The majority of radiulabel from the $1 \mathrm{M} \mathrm{HCl}$ hydrolysis solution was extracted intc methylene chloride. Of the $3.16 \%$ left in the $\mathrm{HCl}$ fraction, $1.37 \%$ was extracted into a : :econd aliquot of methylene chloride after adjustment of the $\mathrm{HCl}$ fraction io bas $\mathrm{c} \mathrm{pH}$ by the addition of $4 \mathrm{M} \mathrm{NH}_{4} \mathrm{OH}$. The radiolabel eluted almost exclusively $n$ fraction $\mathrm{F} 2(82 \pm 1.6 \%)$, less than $1 \%$ being carried over into fractions $\mathrm{F} 3$ and $\mathrm{F} / \mathrm{f}$. The pellets contained $5.93 \pm 0.58 \%$ of the radiolabel.

Chromatographic recovery of RDX in fraction F2 was also examined. The top of Figure 2.8 shows a chromatogram of a $3.66-\mathrm{ppm}$ RDX standard. The HPLC profile of the F2 fraction from spiked bush bean leaves, shown in the bottom of Figure 2.8, demonstrates the recovery of 3.66-ppm RDX from bush bean leaves. Figure 2.9 illustrates the chromatographic profiles of the F2 fractions generated by the triplicatespike experiment. The chromatographic recovery of RDX in fraction F2 was $86.86 \pm$ $3.11 \%$, which agreed well with the radiolabel recovery of $82.09 \pm 1.6 \%$. This experiment demonstrated the efficient recovery and high reproducibility of this analytical methodology for analyzing RDX in plant tissues.

IABLE24. RADIOLABEL DISTRIBUTION AMONG VARIOUS CHEMICAL FRACTIONS OF BUSH BEAN LEAVES SPIKED WITH 3.66 ppm RDX

\begin{tabular}{lr}
\hline Chemical Fraction & \% Total Radiolabel \pm Standard Deviation \\
\hline $\mathrm{HCl}$ & $3.16 \pm 1.81$ \\
$\mathrm{MeCl}$ AN & $82.18 \pm 0.74$ \\
$\mathrm{Aq} \mathrm{Base}$ & $\mathrm{C} .00 \pm 0.00$ \\
$\mathrm{MeCl}$ Base & $1.37 \pm 0.45$ \\
$\mathrm{~F} 1$ & $0.00 \pm 0.00$ \\
$\mathrm{~F} 2$ & $82.09 \pm 1.60$ \\
$\mathrm{~F} 3$ & $0.68 \pm 0.81$ \\
$\mathrm{~F} 4$ & $0.16 \pm 0.28$ \\
& \\
Pellet & $5.93 \pm 0.58$ \\
\hline
\end{tabular}



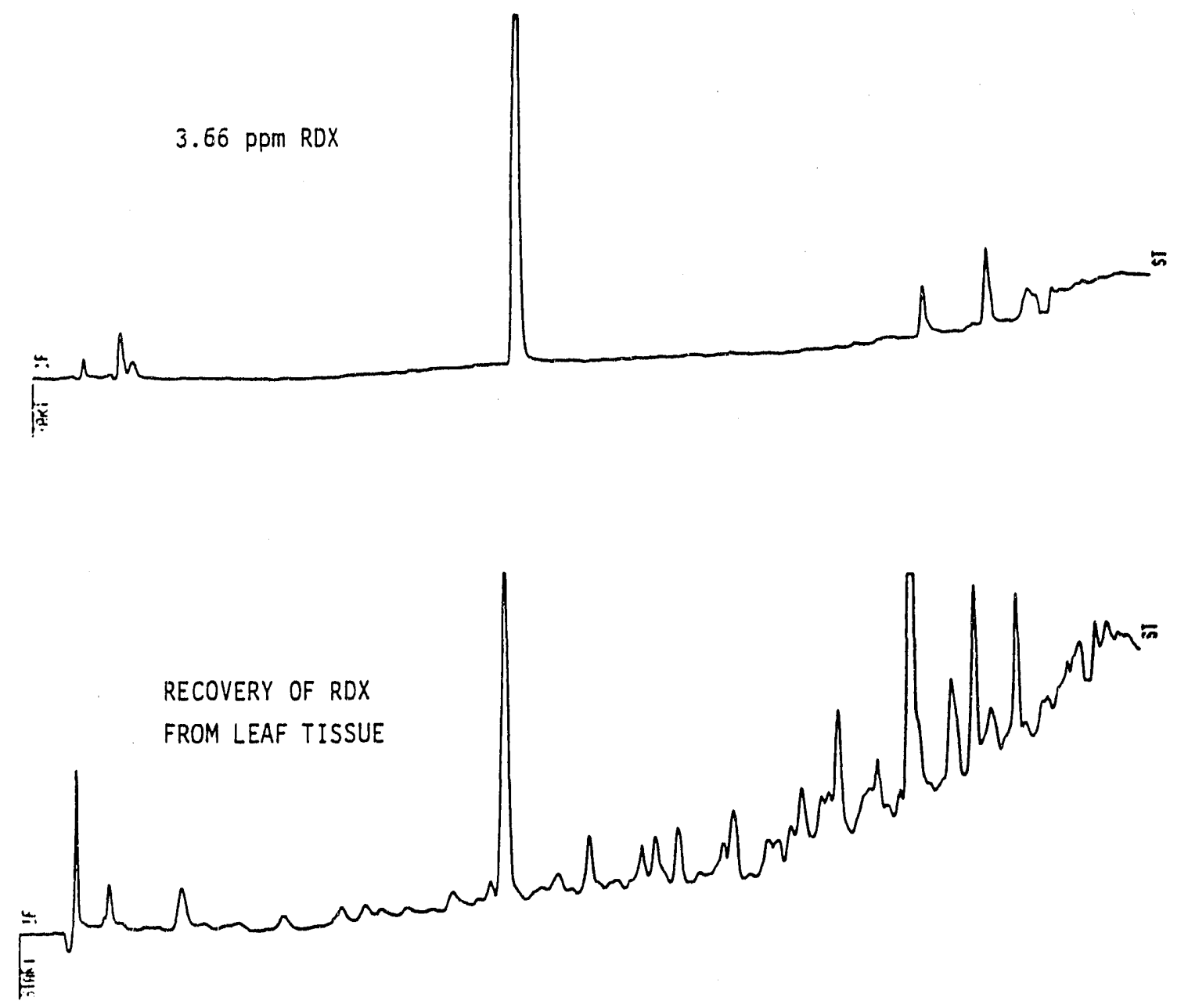

EIGURE28. HPLC CHROMATOGRAMS OF (TOP) A 3.66-ppm SOLUTION OF RDX AND (BOTTOM) THE RECOVERY OF 3.6 ppm RDX FROM BUSH BEAN LEAVES 

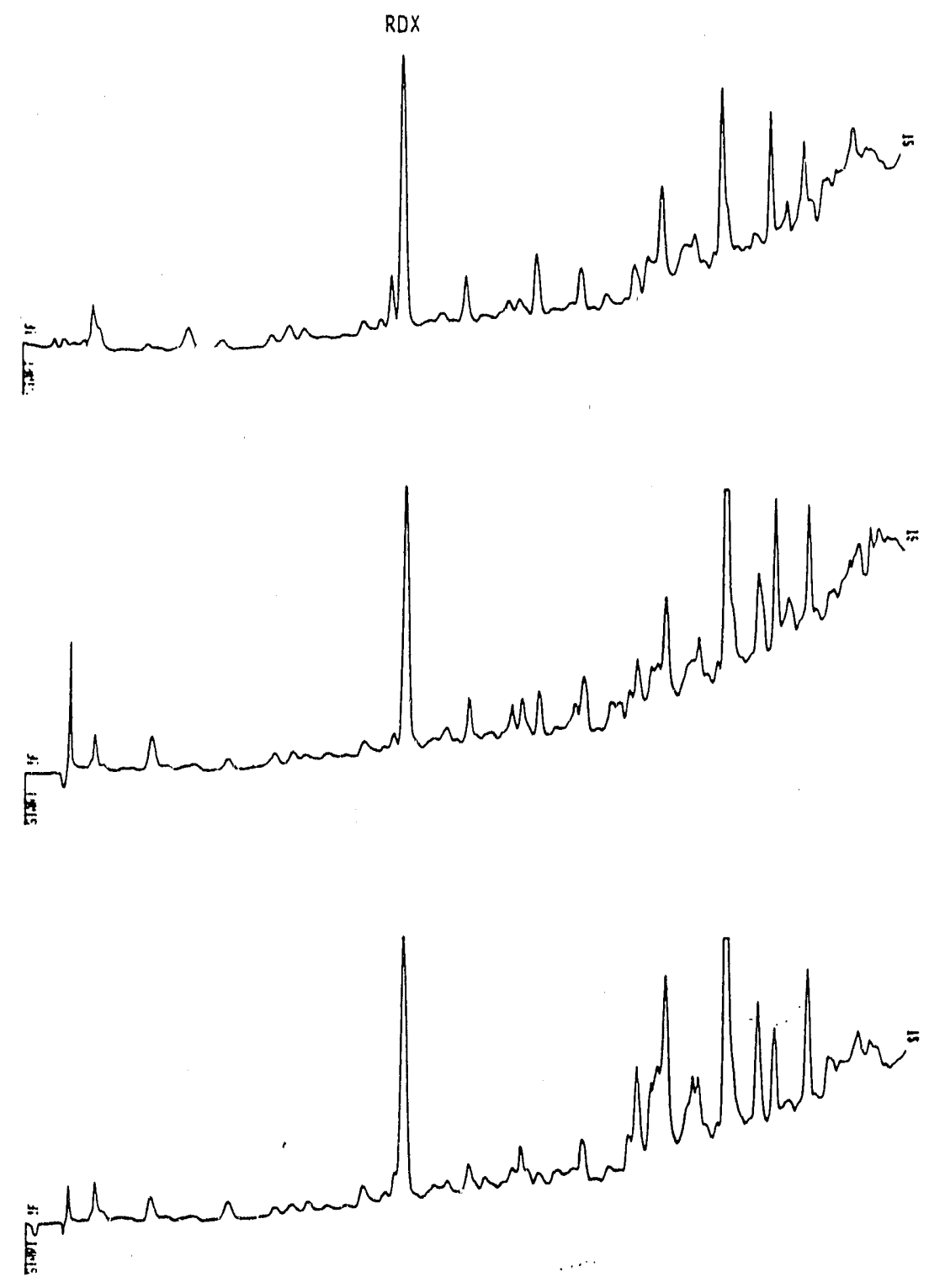

FIGURE 2.9. CHROMATOGRAMS OF THE F2 FRACTION OF BUSH BEAN LEAVES SPIKED WITH 3.66 ppm RDX 


\subsection{BESULTS AND DISCUSSION}

The purpose of this study was to provide an understanding of the environmental fate and behavior of hexahydro-1,3,5-trinitro-1,3,5-triazine (RDX). The methods and approaches used were similar to those used by Cataldo et al. (1990) to study the erivironmental fate of TNT. The important parameters that we investigated include 1) the extent of sorption in soils; 2) the chemical transformations of RDX in soils; and 3) the relative availability of RDX to plants, and the chemical forms of RDX-related residues in plant tissues. In support of these activities, a principal goal was to develop suitable analytical methodology to separate and characterize transformation products in soils and plant tissues.

\subsection{EATE AND BEHAVIOR OF RDX IN SOW}

\subsubsection{Extractability and Mass Balance of RDX in Soil}

Soils aged with $60 \mathrm{ppm}$ RDX for 60 days were extracted and analyzed to determine the extent of sorption and extractability, to determine mass balance and recovery, and to assess possible chemical transformation products. The results are summarized in Table 3.1 and provide the percentage of radiolabel extracied with acetonitrile, the percentage of radioactivity as RDX following HPLC separation of the extracts, and the percentage of radiolabel remaining bound to the soil, as determined by oxidation.

After 60 days of incubation, 77,83 , and $92 \%$ of the amended RDX radioactivity was extractable from Burbank, Palouse and Cinebar soils, respectively. HPLC analysis of these extracts shows that 68,74 , and $85 \%$ of the extractable activity was in the form of RDX. In general, levels of bound residues continued to increase as the soils were aged with RDX. The amount of bound radiolabel was lowest for Burbank (0.5\%) and highest for Cinebar (2\%), and was directly proportional to the total organic-carbon content of the soils (Burbank < Palouse < Cinebar). Although the amount of bound residue increased with time, it should be noted that only a very small relative amount was present as nonextractable residue at the end of the the 2-month study. The lack of significant soil sorption of RDX contrasted sharply with the behavior of TNT (Cataldo et al., 1990), where 31 to $54 \%$ of TNT-derived radiolabel was irreversibly bound to the soils after 60 days.

The mass-balance deficit at 30 and 60 days ranged from $22 \%$ for Burbank soil to $6 \%$ for Cinebar. A similar pattern was noted for TNT, where mass-balance deficits ranged from $32 \%$ to $6 \%$ for Burbank and Cinebar, respectively, after 60 days of incubation (Cataldo et al., 1990). The mass-balance deficit observed for Burbank soil (22\%) was quite large and may represent mineralization or the formation of volatile transformation products in the soil. 
IABLE 3.1. MASS BALANCE OF SOILS CONTAINING $60 \mathrm{ppm} \operatorname{RDX}(n=3)$

\begin{tabular}{llcccc}
\hline Soil & $\begin{array}{c}\text { Time } \\
\text { (days) }\end{array}$ & $\begin{array}{c}\text { \% Radiolabel } \\
\text { in Acetonitrile } \\
\text { Extract }\end{array}$ & $\begin{array}{c}\text { \% Unaltered } \\
\text { RDX }\end{array}$ & $\begin{array}{c}\text { \% Radiolabel } \\
\text { in Soil After } \\
\text { Extraction }\end{array}$ & $\begin{array}{c}\text { Mass-Balance } \\
\text { Deficit (\%) }\end{array}$ \\
\hline
\end{tabular}

Burbank

$\begin{array}{rcccr}0 & 91 \pm 4 & 95 \pm 5 & 0.04 \pm 0.02 & 9 \\ 11 & 100 & 106 & 0.13 \pm 0.02 & 0 \\ 30 & 80 \pm 18 & 82 \pm 17 & 0.43 \pm 0.05 & 20 \\ 60 & 77 \pm 7 & 68 \pm 3 & 0.52 \pm 0.15 & 22\end{array}$

Palouse

$\begin{array}{rcccr}0 & 108 \pm 18 & 112 \pm 19 & 0.09 \pm 0.02 & -8 \\ 11 & 104 \pm 11 & 107 \pm 12 & 0.51 \pm 0.04 & -5 \\ 31 & 97 \pm 20 & 99 \pm 19 & 1.16 \pm 0.11 & 2 \\ 60 & 83 \pm 2 & 74 \pm 1 & 1.10 \pm 0.26 & 16\end{array}$

Cinebar

\begin{tabular}{rrrrr}
0 & $102 \pm 5$ & $104 \pm 5$ & $0.11 \pm 0.01$ & -2 \\
11 & $105 \pm 5$ & $110 \pm 3$ & $1.17 \pm 0.33$ & -6 \\
31 & $93 \pm 4$ & $93 \pm 2$ & $2.31 \pm 0.65$ & 5 \\
60 & $92 \pm 3$ & $85 \pm 3$ & $2.03 \pm 0.20$ & 6 \\
\hline
\end{tabular}

\subsubsection{Rates of RDX Mineralization and Volatilization in Soils}

Gas-exchange experiments using ${ }^{14} \mathrm{C}$-RDX-amended soils were conducted to determine the release of volatile organics and ${ }^{14} \mathrm{CO}_{2}$ from the three soils, and thus to assess the cause of the mass-balance deficits ubserved. Soils were amended with $10 \mathrm{ppm}{ }^{14} \mathrm{C}$-RDX and allowed to equilibrate for 40 days, after which organic volatiles and respiratory $\mathrm{CO}_{2}$ were trapped at daily intervals over 3 consecutive days and counted.

Table 3.2 indicates that no volatile RDX-derived residues are released from soil. Rates of $\mathrm{CO}_{2}$ release ranged from 9.6 to $0.7 \mathrm{ng}$ of RDX-equivalents per day for Burbank and Cinebar soils, respectively. Assuming 60 days of steady-state release, a maximum of $1.3 \%$ of the RDX in Burbank is decomposed to $\mathrm{CO}_{2}$. This is substantially less than indicated by the massbalance deficit of $22 \%$ (Table 3.1). No reliable explanation for this discrepancy is possible. 
IABLE 3.2. VOLATILITY AND MINERALIZATION OF SOIL-AMENDED RDX $(n=6)$

\begin{tabular}{lcccc}
\hline Soil & $\begin{array}{c}\text { Organic } \\
\text { Volatiles(a) } \\
\text { (ng RDX/Day)(c) }\end{array}$ & $\begin{array}{c}\% \\
\text { Total RDX }\end{array}$ & $\begin{array}{c}\text { Daily } \\
\text { Respiration } \\
\text { (ng RDX/Day) }^{(\mathrm{c})}\end{array}$ & $\begin{array}{c}\% \\
\text { Total RDX }\end{array}$ \\
\hline Burbank & $0.0 \pm 0.0$ & $0.0 \pm 0.0$ & $9.6 \pm 4.9$ & $2.3 \times 10^{-4}$ \\
Palouse & $0.0 \pm 0.0$ & $0.0 \pm 0.0$ & $2.1 \pm 0.44$ & $5.1 \times 10^{-5}$ \\
Cinebar & $0.0 \pm 0.0$ & $0.0 \pm 0.0$ & $0.72 \pm(.23$ & $1.5 \times 10^{-5}$ \\
\hline
\end{tabular}

(a) Trapped with two tandem $1 \times 15 \mathrm{~cm}$ XAD resin columns and eluted with $100 \% \mathrm{MeOH}$.
(b) Trapped using $3-\mathrm{N} \mathrm{NaOH}$ ( $10 \mathrm{~mL}$ each in 4 traps in series).
(c) Based on specific activity of soil amendment.

\subsubsection{Chemical Speciation of RDX Residues in Soil}

Radiochromatography was used to verify the presence of RDX and the lack of RDXderived transformation products in the soil extracts. Radiochromatograms of the acetonitrile extracts from Burbank, Palouse, and Cinebar soils are shown in Figures 3.1, 3.2, and 3.3, respectively. As illustrated in each chromatographic profile, RDX is the only ${ }^{14} \mathrm{C}$-containing peak present. The results from this radiochromatography experiment compliment results obtained from the soil mass-balance experiment. Both experiments indicate the extraordinary resistance of RDX to transformation processes in the soils.

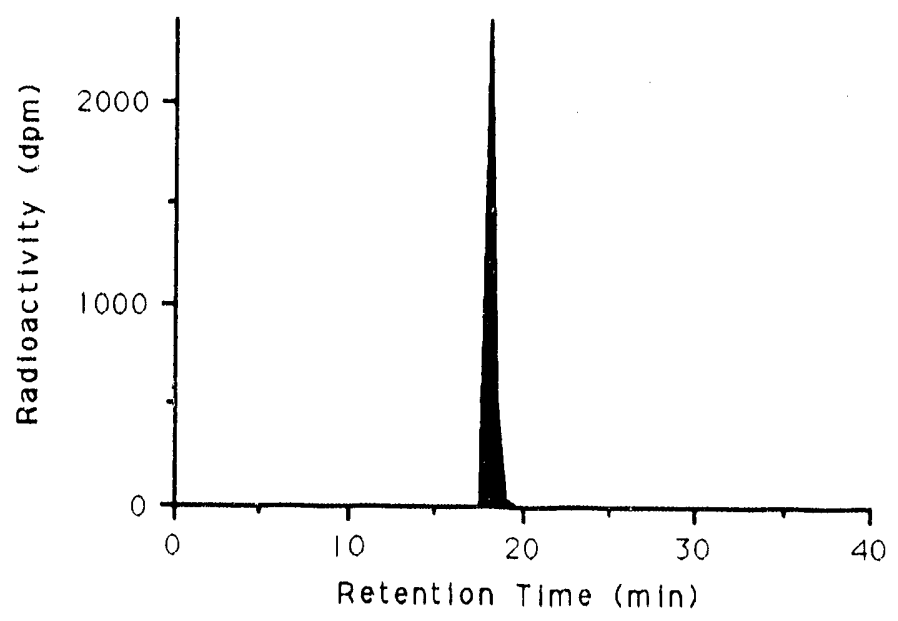

EIGURE 3.1. RADIOCHROMATOGRAM OF BURBANK SOIL 60-DAY EXTRACT 


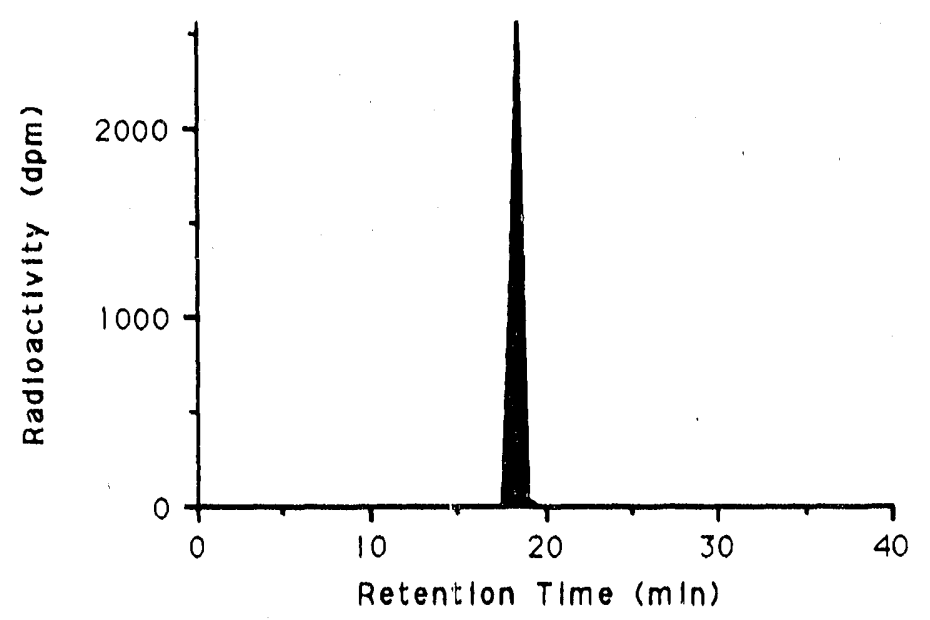

EIGURE 3.2. RADIOCHROMATOGRAM OF PALOUSE SOIL 60-DAY EXTRACT

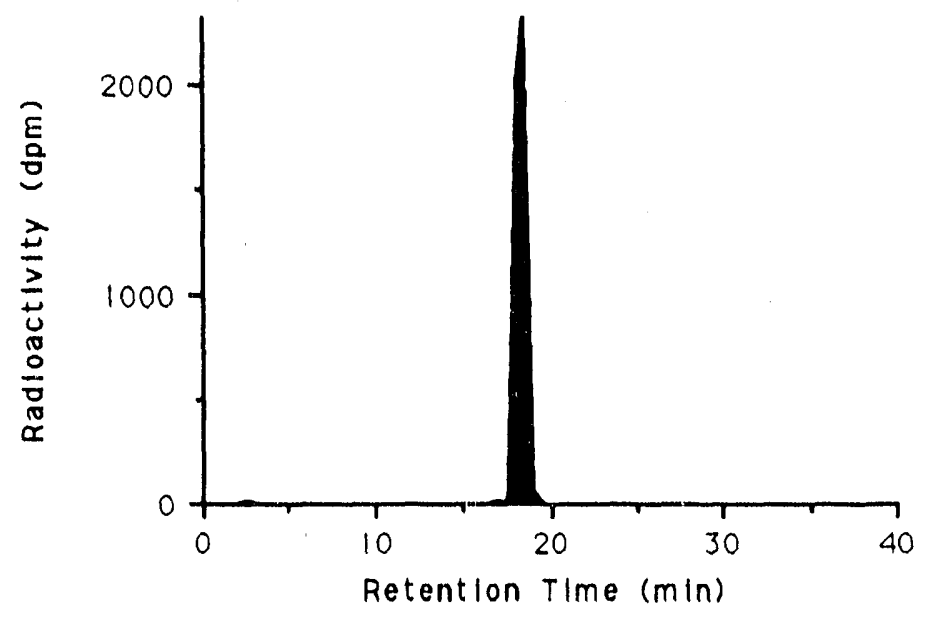

EIGURE 3.3. RADIOCHROMATOGRAM OF CINEBAR SOIL 60-DAY EXTRACT

\subsection{SHORT-TERM PLANT AVALLABILITYAND CHEMICALFATE OF RDX FROM HYDROPONICS}

Hydroponic studies were performed to address several basic needs. The first was to establish the physiological capacity of plants to absorb and transport RDX in the absence of soils and their sorptive components. In other vvords, how does the soluble concentration of RDX affect its biological availability? The second need was to elucidate the extent of 
partitioning of RDX, particularly to the root, which is not amenable to analysis in soil systems. And finally, we needed to establish the short-term chemical fate of RDX in plant tissues, including roots.

Plants were grown in hydroponic solutions containing a total of 1 to $10 \mathrm{ppm}$ RDX, with a total of $5 \mu \mathrm{Cl} / \mathrm{plant}$ of radiolabeled RDX available for uptake. Plant tissues harvested from these experiments were subjected to fractionation and analysis for radioactivity, RDX, and RDX metabolites. The RDX concentrations were selected to provide a range below that which previously had been determined to produce visible phytotoxic effects in soil-grown wheat arid grasses (25 ppm). Data are provided in Section 3.3.1.

\subsubsection{Plant Availability of RDX from Solution Culture}

To determine the uptake rate and relative bioavailability of RDX to the three plant species, a series of experiments were performed in which the roots of plants grown in solution culture were exposed to increasing concentrations of RDX. Solution concentrations ranged from 1 to $10 \mathrm{ppm}$. The average uptake rates ( $\mu \mathrm{g} \mathrm{RDX/g}$ fresh-wt root/h $\pm 1 \mathrm{SD}$ ) by the planis as a function of solution concentration $(\mathrm{ppm})$ for each of the three species are presented in Figure 3.4.

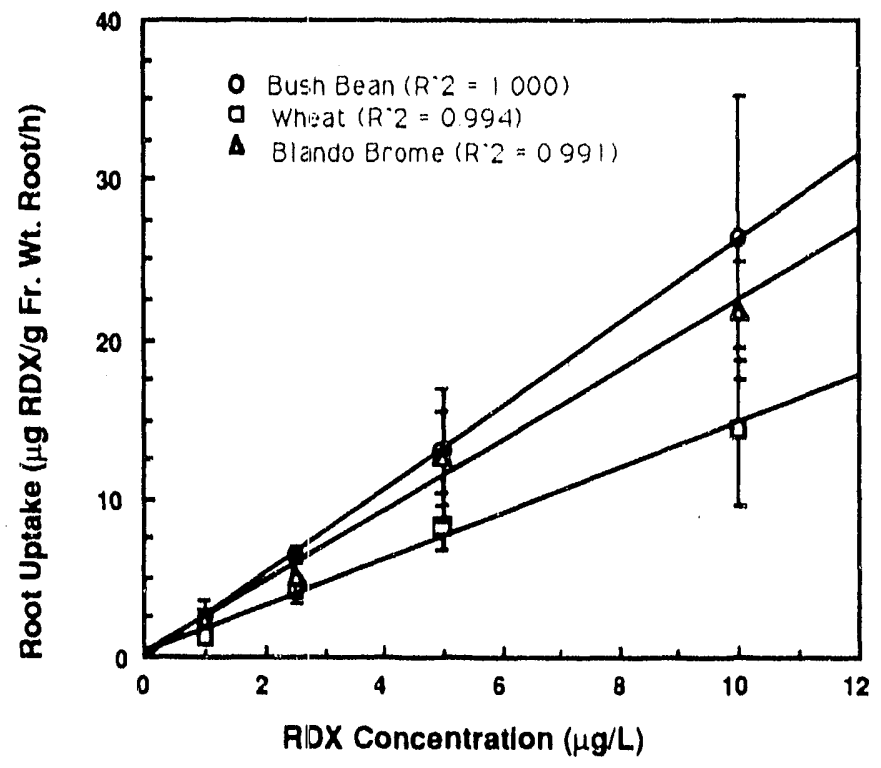

EIGURE 3.4. UPTAKE RATES OF RADIOLABELED RDX BY ROOTS OF BUSH BEAN, WHEAT, AND BLANDO BROME FROM 1, 2.5, 5, AND 10 ppm RDXAMENDED NUTRIENT SOLUTIONS. DATA ARE. AVERAGES \pm STANDARD DEVIATION $(N=3)$. 
Differences were observed in uptake rates of ${ }^{14} \mathrm{C}$-RDX by the roots from the amended nutrient solutions. The bean exhibited a greater rate of uptake, based on root and shoot activity accumulated, compared with blando brome and wheat. For exampie, absorption rates of the ${ }^{14} \mathrm{C}-\mathrm{RDX}$ at solution concentrations of $10 \mathrm{ppm}$ were 26,21 , and $13 \mu \mathrm{g} / \mathrm{g}$ root/h for bush bean, blando brome, and wheat, respectively. Further, the uptake rates for the three species appeared to be linear over the concentrations tested, with no indication of saturation in absorption potential by the plants for soluble, available RDX. These absorption rates are substantially below those observed for TNT, where uptake rates of 900 and $450 \mu \mathrm{g} / \mathrm{g} \mathrm{root/h}$ were noted for bush bean and the grass species, respectively (Cataldo et al., 1990).

To ascertain specific uptake differences between the plant species, we analyzed the uptake data for RDX using Lineweaver-Burke double-reciprocal plots and we calculated a $\mathrm{K}_{\mathrm{s}}$, analogous to the Michaelis-Menten $\mathrm{K}_{\mathrm{m}}$, and a root-absorption rate $\left(V_{\max }\right)$ for each species (Table 3.3). Because $K_{s}$ is analogous to $K_{m}$, one would expect that the lower the $K_{s}$ value, the greater the affinity of transport sites for RDX. For bush bean the average $K_{s}$ was $389 \mu \mathrm{M}$, with $a V_{\max }$ (uptake rate at saturating concentration) of $1 \mu$ moles RDX/g fresh-wt rooth. Wheat exhibited absorption isotherms with an average $K_{s}$ value of 270 and a $V_{\max }$ value of 0.45 $\mu$ moles RDX/g fresh-wt root/h. For blando brome the average $K_{s}$ was calculated to be $96 \mu \mathrm{M}$, with a $V_{\max }$ of $0.24 \mu$ moles $R D X / g$ fresh-wt rooth. These kinetic constants indicate that the moriocot species (blando brome and wheat) may have higher affinities for ADX than does the dicot (bean). Bush bean, however, possessed the higher $V_{\max }$ and would therefore be capable

IABLE 3.3. CALCULATED $K_{S}$ and $V_{\text {max }}$ VALUES FROM DOUBLE-RECIPROCAL PLOTS OF RDX

\begin{tabular}{lcc}
\hline Species & Component & Isotherm \\
\hline \multirow{3}{*}{ Bush Bean } & $\mathrm{K}_{\mathrm{s}}$ & 389 \\
& $\mathrm{~V}_{\max }$ & 0.98 \\
Wheat & $\mathrm{K}_{\mathrm{s}}$ & 270 \\
& $\mathrm{~V}_{\max }$ & 0.45 \\
Blando Brome & $\mathrm{K}_{\mathrm{S}}$ & 96 \\
& $\mathrm{~V}_{\max }$ & 0.24 \\
\hline
\end{tabular}

(a) $K_{s}$ in $\mu M, V_{\text {max }}$ in $\mu$ Moles $R D X / g$ fresh wt root/h. 
of accumulating more of the material over time, on a per-unit-mass-root basis. It should be noted that $V_{\max }$ values, and thus uptake capacity, for RDX are substantially lower than for TNT (Cataido et al. 1990).

\subsubsection{Short-Term Partitioning of INT Within the Plant}

Species differences, including differences in the rate at which RDX may be absorbed by a plant's roots, also could affect partitioning of the absorbed TNT between tissues and organs and the iubsequent chemical fate or metabolism of the partitioned RDX. The description of the metabolic fate of plant-absorbed RDX, which involved analyzing tissues derived from the shortterm hydroponic studies, is reported in Section 3.2.4. The partitioning patterns and effects of elevated ${ }^{4}$ 今-ROX concentrations ( 1 to $10 \mathrm{ppm}$ ) are provided in Table 3.4 .

The tissue accumulation of RDX following $2 \mathrm{~h}$ of absorption indicate that RDX is evenly distributed between root and shoot tissues of all three plant species. This is in striking contrast to the accumulation patterns for TNT (Cataldo et al., 1990), where in bush bean and blando brome, less than $5 \%$ of the absorbed TNT was found in shoot tissues after $2 \mathrm{~h}$ of uptake, and as much as $16 \%$ was found in wheat. Thus RDX is substantially more mobile than TNT in the

TASLE 3.4. DISTRIBUTION OF RADIOCARBON IN PLANTS FOLLOWING A 2-h EXPOSURE IN SOLUTION CULTURE AT VARIOUS TNT CONCENTRATIONS

\begin{tabular}{llccc}
\hline & & \multicolumn{3}{c}{ Exposure-Solution } \\
\cline { 2 - 4 } Species & Tissue & 2.5 & 5 & 10 \\
\hline
\end{tabular}

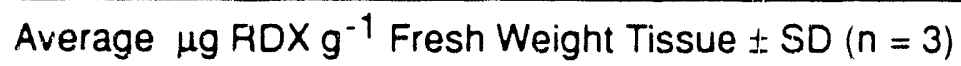

Bush Bean

$\begin{array}{lllll}\text { Root } & 0.46 \pm 0.13 & 1.24 \pm 0.37 & 2.51 \pm 0.56 & 6.04 \pm 1.07 \\ \text { Shoot(a) } & 0.51 \pm 0.20 & 1.53 \pm 0.33 & 2.57 \pm 0.60 & 6.16 \pm 1.42\end{array}$

Wheat

$\begin{array}{lllll}\text { Root } & 0.43 \pm 0.12 & 1.31 \pm 0.27 & 1.98 \pm 0.46 & 2.43 \pm 0.25 \\ \text { Shoot }(a) & 0.39 \pm 0.23 & 1.35 \pm 0.28 & 1.53 \pm 0.31 & 2.02 \pm 0.28\end{array}$

Biando Brome

$\begin{array}{lllll}\text { Root } & 0.49 \pm 0.13 & 1.13 \pm 0.28 & 2.69 \pm 0.46 & 4.66 \pm 0.93 \\ \text { Shoot (a) } & 0.38 \pm 0.06 & 0.82 \pm 0.32 & 1.38 \pm 0.62 & 3.78 \pm 0.81\end{array}$

(a) Includes stem plus leaves. 
plant, and the plant root has little storage capacity for RDX. The difference in mobility of RDX and TNT would indicate that RDX may have a more pronounced impact on the human food chain.

\subsubsection{Bespiration and Volatility of RDX by Plants Grown in Solution Culture}

RDX and related residues that are absorbed by plant roots and exported to the stem and leaves may 1) be further metabolized to a form innocuous to the plant; 2) be sequestered or stored; 3) undergo further metabolic conversions to achieve a final form of $\mathrm{CO}_{2}$; or 4) pass through the plant through the transpiration stream to be released to the atmosphere essentially unchanged. To determine the potential for the latter two processes, a 28-day-old hydroponicgrown soybean was placed in a beaker containing a $10-p p m{ }^{14} \mathrm{C}$-RDX-amended nutrient solution. The beaker was then placed into the $\mathrm{CO}_{2} /$ volatiles trapping chamber. Over $72 \mathrm{~h}$, volatile organic compounds and $\mathrm{CO}_{2}$ emissions were assayed from the shoot and root portions of the plant. From the collected data, we constructed a ${ }^{14} \mathrm{C}$ mass-balance between the initial and remaining label in the nutrient solution and the plant.

The results, given in Table 3.5, demonstrate a mass-balance recovery of approximately $107 \%$. Over a 72 -h period, $15 \%$ of the RDX, or $692 \mu \mathrm{g} \mathrm{RDX}$, was accumulated in the plant. Respiratory losses from the root accounted for $21 \mu \mathrm{g}$, or $0.47 \%$ of the total RDX supplied. In previous studies (Cataldo et al., 1990), respiratory losses of TNT were not observed. There was no detectable loss of label in either an organic form or as $\mathrm{CO}_{2}$ from the foliage, respiratory losses of TNT were not observed of the bean plant. Radioactivity within the plant was evenly distributed between leaves and root.

These results indicate that RDX or transformed residues are not directly volatilized from foliage to the atmosphere. Furthermore, oxidative metabolism of the RDX or its transport products occurred over the 3-day period. This phenomenon, whether occurring in the root or as a result of mycorhizal associations, represents a significant loss rate for RDX ( $7 \mu \mathrm{g} / \mathrm{day}$ of the $4400 \mu \mathrm{g}$ supplied in solution).

\subsubsection{Chemical Fate of RDX in Hydroponically Grown Plants}

Hydroponically grown plants were used to establish the analytical procedures needed to resolve the relative availability and fate of RDX and associated residues and their chemical fate once accumulated. This experimental system permits close control of initial chemical forms in solution and eliminates those processes occurring in soil which are likely to confuse initial steps in elucidating RDX fate, namely sorption and soil-based chemical transformation of the parent compound. 
IABLE 3.5. DISTRIBUTION OF RADIOLABELED RDX IN A HYDROPONICALLY GROWN BUSH BEAN FOLLOWING A 72-h EXPOSURE TO A $10 \mathrm{ppm}$ SOLUTION. PLANT WAS MAINTAINED UNDER NORMAL GROWTH CONDITIONS IN A SPLIT CHAMBER

\begin{tabular}{|c|c|c|}
\hline Component & $\operatorname{RDX}(\mathrm{mg})$ & $\%$ Total Initial ${ }^{14} \mathrm{C}$ \\
\hline Original $\left[{ }^{14} \mathrm{C}\right] \mathrm{RD} \times$ Solution & $4.438^{(a)}$ & 100.00 \\
\hline Plant Tissue & $0.692^{(b)}$ & 15.61 \\
\hline Shoot $\mathrm{CO}_{2}$ (c) & $n . d^{(d)}$ & 0.00 \\
\hline Shoot $X A \bar{D}^{(\theta)}$ & n.d. & 0.00 \\
\hline Root $\mathrm{CO}_{2}{ }^{(\mathrm{c})}$ & 0.021 & 0.47 \\
\hline Root $X A D^{(\theta)}$ & n.d & 0.00 \\
\hline 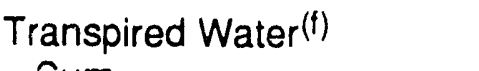 & 0.001 & $\underline{0.03}$ \\
\hline Sum & $\overline{0.714}$ & 16.11 \\
\hline $\mathrm{CaCl}_{2}$ Root Wash & 0.049 & 1.12 \\
\hline Methanol Root Wash & 0.567 & 12.78 \\
\hline Final $\left[{ }^{14} \mathrm{C}\right] \mathrm{RD} \times$ Solution & $3.424^{(f)}$ & 77.16 \\
\hline Sum & 4.754 & 107.17 \\
\hline \multicolumn{3}{|c|}{$\begin{array}{l}\text { (a) Based on HPLC analysis of the 350-mL starting solution. } \\
\left.\text { (b) Determined by tissue oxidation and based on }{ }^{14} \mathrm{C}\right] \mathrm{RDX} \text { equivalents from solution's specific activity. } \\
\text { (c) Based on }\left[{ }^{14} \mathrm{C}\right] \mathrm{RDX} \text { starting-solution equivalents from } \mathrm{NaOH} \text { traps. } \\
\text { (d) Not detected. } \\
\text { (e) Based on }\left[{ }^{14} \mathrm{C}\right] \mathrm{RDX} \text { starting-solution equivalents from XAD resin columns. } \\
\text { (f) Based on }\left[{ }^{14} \mathrm{C}\right] \mathrm{RDX} \text { starting-solution equivalents in condensed transpired water in upper (shoot) chamber. }\end{array}$} \\
\hline
\end{tabular}

We prepared hydroponic solutions which contained approximately $5 \mathrm{ppm}$ RDX and $5.6 \mu \mathrm{Ci} / 500 \mathrm{~mL}$. The solutions were filter-sterilized and placed in autoclaved $600-\mathrm{mL}$ beakers to minimize bacterial contamination, which could promote transformation of RDX. For each plant type, three control solutions and six exposure solutions were prepared. Two of the control solutions were exposed to the full intensity of the growth-chamber lights. The first of these solutions was aerated, whereas the second was not. The third control solution was aerated and the beaker was placed in an opaque sheath to protect RDX from photodecomposition. Six plants were placed in the remaining beakers and allowed to grow for 1 or 7 days, after which they were harvested. Samples for liquid-scintillation spectrometry and HPLC were removed immediately after preparing the solutions and after harvesting each group of plants. 
The results of the hydroponic-solution analysis are summarized in Table 3.6. Analysis of the control solutions showed a consistent loss of both radiolabel and RDX from the bubbled controls exposed to light. This result initially was surprising, given the low vapor pressure of RDX. The most plausible explanation is that RDX was lost from the beaker through aerosolization, rather than volatilization. A corresponding loss was not observed in the dark aerated control because this beaker was covered, to exclude light. With the exception of the aforementioned aerated light-exposed control, losses of radiolabel from the control beakers were minimal. Calculations of specific activity of the control solutions and their HPLC profiles both indicate that transformations did not occur.

Analyses of solutions used to maintain plants clearly show losses of RDX from plant uptake. In contrast with TNT-containing hydroponic solutions, in RDX solutions root-catalyzed transformation products were not observed. HPLC chromatograms of the hydroponic solutions indicated only a single peak from RDX. The lack of transformation of RDX is further evidenced by the specific activity of the hydroponic solutions. The average specific activity in the control solutions was $1.14 \pm 0.03 \mu \mathrm{Ci} / \mathrm{mg} \operatorname{RDX}(n=27)$. If transformations were to occur during exposure to the plants, one would expect an increase in the specific activity of the solutions. Since the average specific activity of the plant-containing solutions [average of $1.14 \pm 0.02$ $(n=18)]$ was the same as the control solutions, transformations of RDX did not occur.

To estimate the extent of RDX metabolite conjugation, an acid-hydrolyzed leaf sample and its corresponding ether extract were compared with an identical tissue sample homogenized in water and extracted with diethyl ether. Leaf tissue from a plant exposed to hydroponic culture for 7 days was chosen for this study to allow sufficient tirne for the plant to metabolize and/or sequester RDX. The results showed 56 and $67 \%$ of the total radiolabel to be present in the ether extracts of the acid hydrolyzed and the water hydrolyzed samples, respectively. After extraction, the acid layer contained $21 \%$ of the radiolabel, whereas the water phase contained $15 \%$. From this analysis it is clear that the majority of radiolabel was readily extracted into diethyl ether, and, therefore, was not present in the plant tissue as polar acid-hydrolyzable conjugates. Since metabolism may favor the formation of polar conjugates in mature plants grown under chronic exposure conditions, and since recoveries of RDX were acceptable with acid hydrolysis, this step was retained to broaden the applicability of the analytical scheme.

In the following presentation of results obtained during the fractionation of tissue from plarits grown in RDX-containing hydroponic solutions, the data are presented in terms of both percentage of total radiolabel and micrograms of RDX equivalents present in each chemical fraction. This facilitates easy visual comparisons between different experimental variables. Also for ease of comparison, the concentration of actual RDX in fraction F2, as determined by HPLC analysis, is included within the RDX-equivalent data tables. The concentration units of 
IABLE 3.6. QUANTITY OF RDX AND RADIOLABEL IN HYDROPONIC SOLUTIONS AT THE BEGINNING OF THE STLDY AND AT THE TWO HARVEST TIMES

\begin{tabular}{|c|c|c|c|c|c|c|}
\hline \multirow[b]{2}{*}{$\begin{array}{l}\text { Species/ } \\
\text { Treatment }\end{array}$} & \multicolumn{2}{|c|}{ O day } & \multicolumn{2}{|c|}{1 day } & \multicolumn{2}{|c|}{7 day } \\
\hline & $\begin{array}{c}\mu \mathrm{Cl} / \\
\text { Beaker }\end{array}$ & $\begin{array}{l}\text { mg RDX } \\
\text { Beaker }\end{array}$ & $\begin{array}{c}\mu \mathrm{Cl} / \\
\text { Beaker }\end{array}$ & $\begin{array}{l}\text { mg RDXI } \\
\text { Beaker }\end{array}$ & $\begin{array}{l}\mu \mathrm{Ci} / \\
\text { Beaker }\end{array}$ & $\begin{array}{l}\text { mg RDX } \\
\text { Beaker }\end{array}$ \\
\hline \multicolumn{7}{|l|}{ Bush Bean } \\
\hline $\begin{array}{l}\text { Control, light, } \\
\text { bubbled }\end{array}$ & 5.76 & 5.12 & 5.41 & 4.79 & 4.59 & 3.88 \\
\hline $\begin{array}{l}\text { Control, light, } \\
\text { not bubbled }\end{array}$ & 5.80 & 5.13 & 5.75 & 5.06 & 5.37 & 4.50 \\
\hline $\begin{array}{l}\text { Control, dark, } \\
\text { bubbled }\end{array}$ & 5.74 & 5.12 & 5.51 & 4.90 & 5.36 & 4.70 \\
\hline Plants 1-3 & $5.73 \pm 0.10$ & $5.14 \pm 0.02$ & $5.14 \pm 0.15$ & $4.53 \pm 0.04$ & $\ldots$ & $\cdots$ \\
\hline Plants 7-9 & $5.72 \pm 0.03$ & $5.10 \pm 0.00$ & $\ldots$ & $\cdots$ & $2.12 \pm 0.85$ & $1.80 \pm 0.73$ \\
\hline \multicolumn{7}{|l|}{ Wheat } \\
\hline $\begin{array}{l}\text { Control, light, } \\
\text { bubbled }\end{array}$ & 5.89 & 5.02 & 5.90 & 5.29 & 3.92 & 3.27 \\
\hline $\begin{array}{l}\text { Control, light, } \\
\text { not bubbled }\end{array}$ & 5.77 & 5.06 & 5.64 & 4.95 & 5.60 & 4.75 \\
\hline $\begin{array}{l}\text { Control, dark, } \\
\text { bubbled }\end{array}$ & 5.67 & 5.10 & 4.98 & 4.35 & 5.57 & 5.00 \\
\hline Plants 1-3 & $5.82 \pm 0.14$ & $5.08 \pm 0.02$ & $4.70 \pm 0.26$ & $4.13 \pm 0.35$ & $\cdots$ & $\ldots$ \\
\hline Plants 7-9 & $5.90 \pm 0.07$ & $5.16 \pm 0.07$ & $\cdots$ & $\cdots$ & $2.69 \pm 0.35$ & $2.34 \pm 0.31$ \\
\hline \multicolumn{7}{|l|}{ Blando Brome } \\
\hline $\begin{array}{l}\text { Control, light, } \\
\text { bubbled }\end{array}$ & 5.62 & 4.90 & 5.60 & 4.76 & 5.16 & 4.49 \\
\hline $\begin{array}{l}\text { Control, light, } \\
\text { not bubbled }\end{array}$ & 5.50 & 4.89 & 5.34 & 4.71 & 5.34 & 4.65 \\
\hline $\begin{array}{l}\text { Control, dark, } \\
\text { bubbled }\end{array}$ & 5.48 & 4.88 & 5.35 & 4.74 & 5.35 & 4.85 \\
\hline Plants 1-3 & $5.48 \pm 0.07$ & & $4.88 \pm 0.06$ & $4.80 \pm 0.10$ & $4.20 \pm 0.06$ & $\cdots$ \\
\hline Plants 7-9 & $5.55 \pm 0.01$ & $4.86 \pm 0.02$ & -.-- & $\ldots$ & $2.27 \pm 0.46$ & $2.06 \pm 0.40$ \\
\hline
\end{tabular}


the HPLC determinations are $\mu \mathrm{g} R D X / g$ fresh-weight tissue, or equivalently, $\mu \mathrm{g} R D X$, since $1.00 \mathrm{~g}$ of tissue was fractionated. Should all of the radiolabel contained in fraction $\mathrm{F} 2 \mathrm{be}$ speciated as RDX, the $\mu \mathrm{g}$ RDX-equivalent values for this fraction and the values determined by HPLC analysis should be equal.

The results for fractionation of bush bean tissues after 1 and 7 days of exposure to 5 ppm RDX (5.6 $\mu \mathrm{Ci} / 500 \mathrm{~mL})$ hydroponic cultures are summarized in Tables 3.7 through 3.9. Figure 3.5 illustrates representative HPLC profiles of F2 fractions of bush bean leaf (top), stem (center), and roots (bottom) tiss'ses from a plant exposed to hydroponic solution for 1 day. It is immediately evident that large quantities of RDX were present in these tissues. The distributions shown in Tables 3.7 through 3.9 illustrate that RDX is accumulated by bush beans and that a surprisingly small amount of RDX is metabolized even in the plants exposed for a 7day period. After a 1-day exposure to the $5 \mathrm{ppm}$ solution of RDX, concentrations of RDX in leaf tissue approached 20 ppm (Table 3.7). The amounts of RDX contained in the stem and root tissues of these 1-day plants were approximately $10 \mathrm{ppm}$. Since practically all the radiolabel was present in fraction F2, with very little contained in the polar aqueous-base and F4 fractions (Table 3.8), it is apparent that RDX is accumulated and not immediately metabolized. Further evidence for this contention is provided by chromatographic analysis of the F2 fractions. Concentrations of RDX obtained by HPLC analysis agree well with those

IABLE 3.7. MICROGRAM RDX EQUIVALENTS IN CHEMICAL FRACTIONS OF BUSH $\operatorname{BEAN}^{(a)}$

\begin{tabular}{|c|c|c|c|c|c|c|}
\hline \multirow[b]{2}{*}{ Fraction } & \multicolumn{3}{|c|}{ Dax 1} & \multicolumn{3}{|c|}{ Day 7} \\
\hline & Leaves & Stem & Roots & Leaves & Stem & Roots \\
\hline $\mathrm{HCl}$ & $3.9 \pm 0.6$ & $1.8 \pm 0.4$ & $2.4 \pm 0.3$ & $31.7 \pm 3.6$ & $9.1 \pm 1.0$ & $8.7 \pm 0.8$ \\
\hline $\mathrm{Et}_{2} \mathrm{O}$ acid-neutral & $19.0 \pm 2.7$ & $11.9 \pm 0.5$ & $8.7 \pm 1.1$ & $82.2 \pm 9.4$ & $12.3 \pm 2.4$ & $7.9 \pm 2.2$ \\
\hline Aq Base & $1.2 \pm 0.5$ & $0.6 \pm 0.3$ & $1.1 \pm 0.6$ & $20.1 \pm 3.5$ & $7.3 \pm 1.3$ & $7.4 \pm 0.2$ \\
\hline $\mathrm{Et}_{2} \mathrm{O}$ base & $2.3 \pm 0.4$ & $1.2 \pm 0.3$ & $0.9 \pm 0.1$ & $11.0 \pm 1.8$ & $1.3 \pm 0.5$ & $0.9 \pm 0.4$ \\
\hline$F 1$ & 0 & 0 & 0 & 0 & 0 & 0 \\
\hline $\mathrm{F} 2$ & $18.4 \pm 3.6$ & $11.1 \pm 1.1$ & $9.5 \pm 1.6$ & $68.8 \pm 7.2$ & $10.3 \pm 2.4$ & $6.1 \pm 2.4$ \\
\hline F3 & $0.6 \pm 0.4$ & $0.4 \pm 0.1$ & $0.03 \pm 0.06$ & $3.3 \pm 1.0$ & $0.2 \pm 0.1$ & $0.5 \pm 0.1$ \\
\hline $\mathrm{F} 4$ & 0 & 0 & $0.08 \pm 0.03$ & $10.1 \pm 1.3$ & $0.5 \pm 0.2$ & $0.7 \pm 0.1$ \\
\hline$R D X$ in $F 2^{(b)}$ & $18.6 \pm 3.6$ & $10.9 \pm 0.7$ & $9.4 \pm 1.5$ & $96.6 \pm 26.7$ & $11.1 \pm 2.5$ & $6.2 \pm 2.5$ \\
\hline
\end{tabular}

(a) Values are the averages from analysis of three plants.

(b) Values determined by HPLC analysis of fraction F2. 
IABLE 3.8. PERCENTAGE OF TOTAL RADIOACTIVITY, BASED ON OXIDATION, IN CHEMICAL FRACTIONS OF BUSH BEAN AFTER 1 DAY(a)

\begin{tabular}{lccc}
\hline & & Day 1 & \\
\cline { 2 - 4 } Fraction & Leaves & Stem & Roots \\
\hline & $14 \pm 1$ & $12 \pm 3$ & $18 \pm 2$ \\
$\mathrm{HCl}$ & $67 \pm 4$ & $77 \pm 9$ & $65 \pm 7$ \\
$\mathrm{Et}_{2} \mathrm{O}$ acid-neutral & $4 \pm 1$ & $4 \pm 2$ & $8 \pm 3$ \\
$\mathrm{Aq} \mathrm{Base}$ & $8 \pm 0$ & $8 \pm 3$ & $7 \pm 1$ \\
$\mathrm{Et}_{2} \mathrm{O}$ base & 0 & 0 & 0 \\
$\mathrm{~F} 1$ & $66 \pm 4$ & $72 \pm 10$ & $71 \pm 4$ \\
F2 & $2 \pm 1$ & $2 \pm 1$ & $0.3 \pm 0.6$ \\
F3 & 0 & 0 & $0.7 \pm 0.6$ \\
F4 & & & $7.7 \pm 0.6$ \\
Pellet & $5.7 \pm 0.6$ & $4.7 \pm 0.6$ & \\
\hline
\end{tabular}

(a) Values are the averages from analysis of 3 plants.

IABLE 3.9. PERCENTAGE OF TOTAL RADIOACTIVITY, BASED ON OXIDATION, IN CHEMICAL FRACTIONS OF BUSH BEAN AFTER 7 DAYS(a)

\begin{tabular}{|c|c|c|c|}
\hline \multirow[b]{2}{*}{ Fraction } & \multicolumn{3}{|c|}{ Dax 7} \\
\hline & Leaves & Stem & Roots \\
\hline $\mathrm{HCl}$ & $23 \pm 3$ & $27 \pm 5$ & $33 \pm 2$ \\
\hline $\mathrm{Et}_{2} \mathrm{O}$ acid-neutral & $60 \pm 8$ & $35 \pm 6$ & $30 \pm 6$ \\
\hline Aq Base & $14 \pm 2$ & $21 \pm 5$ & $28 \pm 3$ \\
\hline $\mathrm{Et}_{2} \mathrm{O}$ base & $8 \pm 2$ & $4 \pm 1$ & $4 \pm 2$ \\
\hline $\mathrm{F} 1$ & 0 & 0 & 0 \\
\hline F2 & $50 \pm 5$ & $30 \pm 6$ & $23 \pm 7$ \\
\hline F3 & $3 \pm 1$ & $1 \pm 1$ & $2 \pm 0$ \\
\hline F4 & $7 \pm 1$ & $1 \pm 1$ & $3 \pm 1$ \\
\hline Pellet & $5 \pm 1$ & $15 \pm 3$ & $14 \pm 1$ \\
\hline
\end{tabular}

(a) Values are the averages from analysis of 3 plants. 

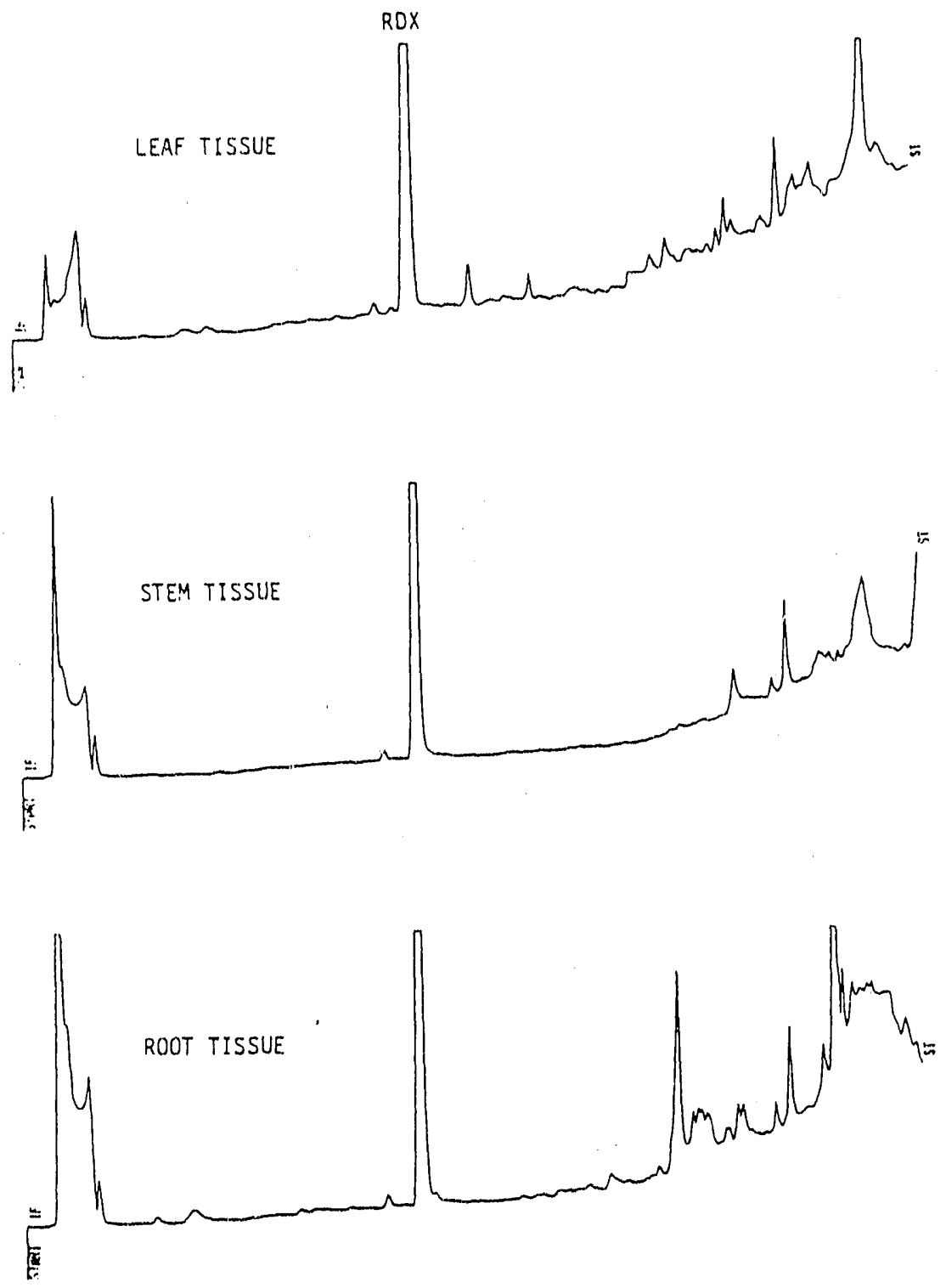

EIGURE 3.5. CHROMATOGRAMS OF THE F2 FRACTION OF (TOP) BUSH BEAN LEAF, (CENTER) STEM, AND (BOTTOM) ROOT TISSUES. PLANT WAS EXPOSED TO RDX-CONTAINING HYDROPONIC SOLU,'ION FOR 1 DAY 
obtained by radiocounting, indicating that RDX accounts for all the material contained within fraction F2. The bioaccumuliaion trend was even more pronounced in the 7-day exposure plants (Table 3.9). We see here the first indications of a small amount of metabolism of RDX. In the 7-day exposure plants, foliar concentrations approach 100-ppm RDX, giving clear evidence of the bioaccumulation of this munition compound.

By the 7-day harvest, significant amounts of radiolabel began to appear in the F4 and aqueous-base fraction of the fractionated leaf tissue. Twenty percent of the total radiolabel had undergone sufficient metabolism to be nonextractable into diethyl ether (aqueous-base fraction) and $10 \%$ of the radiolabel was contained in the extractable yet polar fraction $\mathrm{F} 4$. The stem and root tissues displayed little affinity for RDX, containing only 11 and 6 ppm RDX, respectively. The undeniable evidence for plant bioaccumulation of RDX was by far the most significant finding of this experiment.

An unusual trend was indicated by the amount of radiolabel contained in the bush bean pellets. As clearly indicated by the data, root uptake of RDX, transport to the leaf tissue, and accumulation in the leaf tissue readily occurred. One would expect that after transporting it to the leaf tissue, the plant would render the foreign material innocuous both by metabolically alterating it and by physically incorporating the material in nonaccessible forms such as cellulose. One would therefore expect that the pellet of the 7-day leaf tissue would contain significantly more radiolabel than that of the 1-day plant. Contrary to expectations, the amounts of sequestered radiolabel contained in the leaf pellets were about $5 \%$ in bcth 1 - and 7-day plants. Interestingly, the 7-day root tissue contained approximately twice the nonextractable radiolabel of the 1-day roots. These unusual results suggest that the roots rather than the leaf tissue were initially involved in irnmobilizing and sequestering this xenobiotic.

The F2 fractions from bush bean roots and shoots from both 1- and 7-day plants were examined by radiochromatography to provide further evidence that fraction F2 contains only RDX. These radiocarbon profiles are presented in Figures 3.6 through 3.9. In all of these profiles, RDX (retention time of $17.5 \mathrm{~min}$ ) was the only radiocarbon-containing species present. Minor metabolites were not observed in fraction F2 even in the 7-day-exposure plant tissues.

We chemically fractionated the tissues from the monocotyledon plants, wheat and blando brome, to determine the extent of formation of polar residues. The microgram RDX equivalent distribution of radiolabel for wheat plants grown in hydroponic solution for 1 and 7 days is presented in Table 3.10, and the percentage of total radiolabel distribution is given in Table 3.11. As was observed with the bush bean plants, RDX was quickly accumulated in the foliar tissues of wheat. The shoot tissue contained about 40 pprin RDX in the 1-day plants, with 


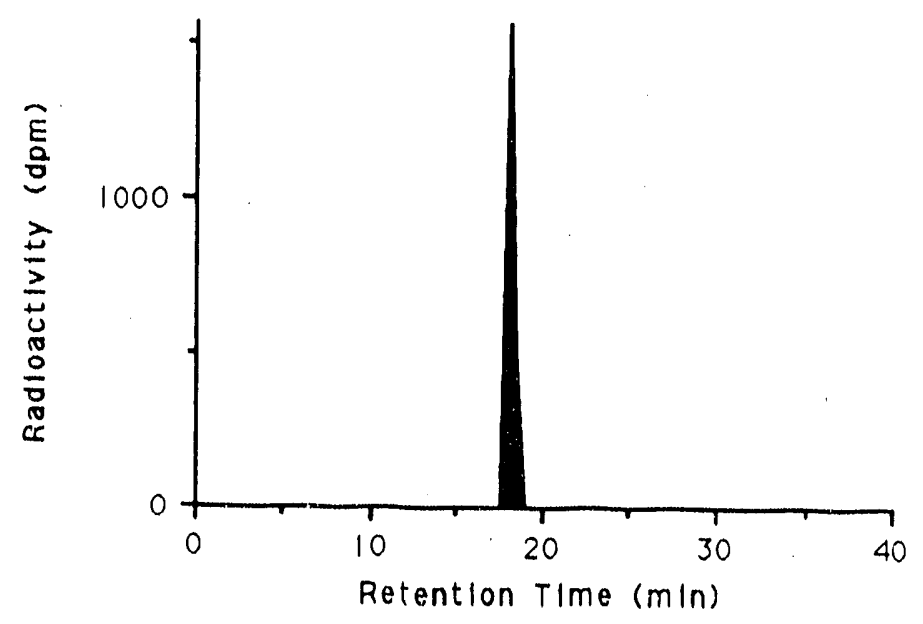

FIGURE 3.6. RADIOCHROMATOGRAM OF THE F2 FRACTION OF BUSH BEAN ROOT FROM A PLANT GROWN IN HYDROPONIC CULTURE FOR 1 DAY

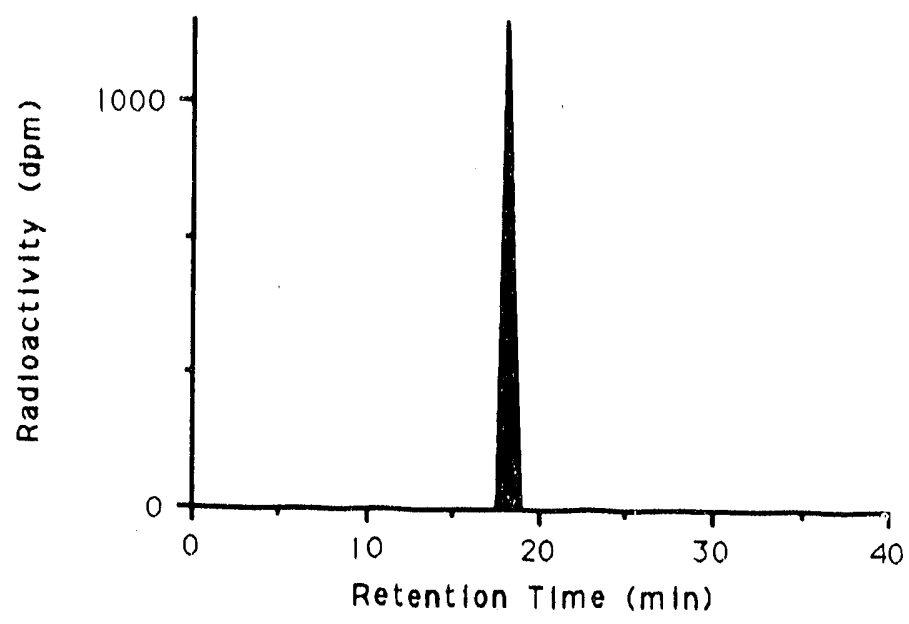

EIGURE 3.7. RADIOCHROMATOGRAM OF THE F2 FRACTION OF BUSH BEAN LEAVES FROM A PLANT GROWN IN HYDROPONIC CULTURE FOR 1 DAY 


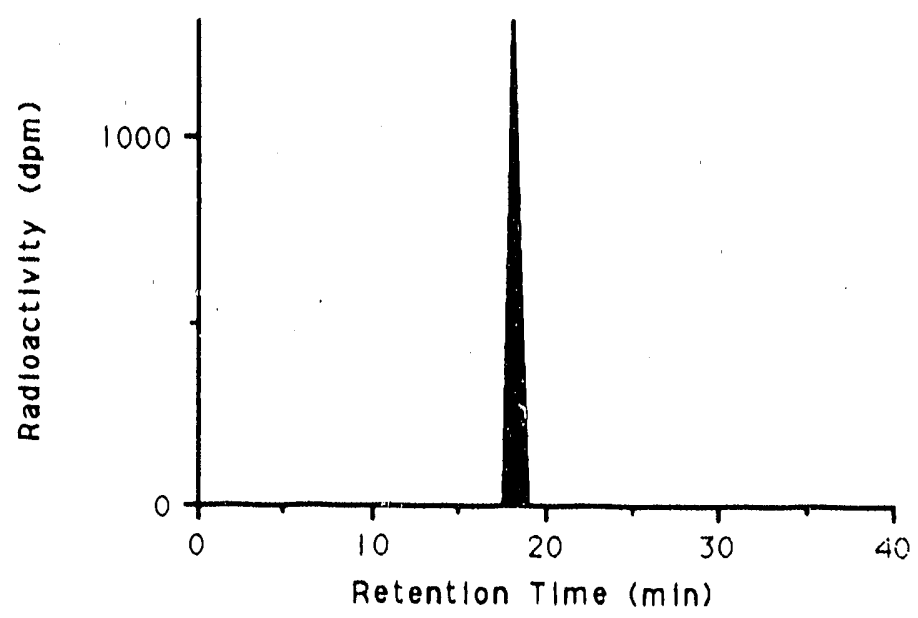

EIGURE 3.8. RADIOCHROMATOGRAM OF THE F2 FRACTION OF BUSH BEAN ROOT FROM A PLANT GROWN IN HYDROPONIC CULTURE FOR 7 DAYS

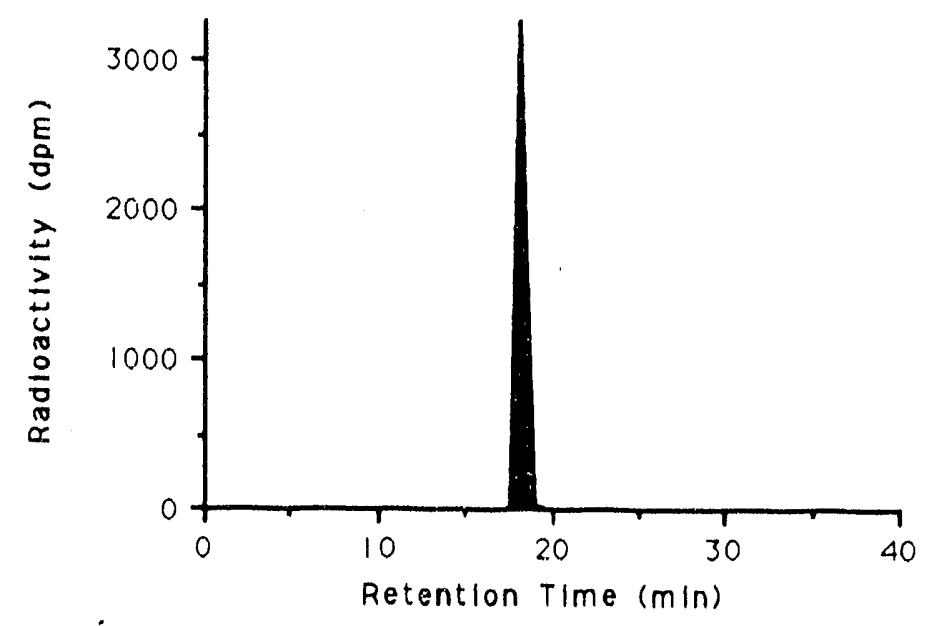

EIGURE 3.9. RADIOCHROMATOGRAM OF THE F2 FRACTION OF BUSH BEAN LEAVES FROM A PLANT GROWN IN HYDROPONIC CULTURE FOR 7 DAYS 
IABLE 3.10. MICROGRAM RDX EQUIVALENTS IN CHEMICAL FRACTIONS OF WHEAT(a)

\begin{tabular}{|c|c|c|c|c|}
\hline \multirow[b]{2}{*}{ Fraction } & \multicolumn{2}{|c|}{ Day 1} & \multicolumn{2}{|c|}{ Day 7} \\
\hline & Shoot & Foot & Shoot & Root \\
\hline $\begin{array}{l}\mathrm{HCl} \\
\mathrm{Et}_{2} \mathrm{O} \text { acid-neutral } \\
\mathrm{Aq} \text { Base } \\
\mathrm{Et}_{2} \mathrm{O} \text { base }\end{array}$ & $\begin{array}{c}11.4 \pm 1.2 \\
37.8 \pm 1.2 \\
6.2 \pm 0.8 \\
4.7 \pm 0.4\end{array}$ & $\begin{array}{l}2.2 . \pm 0.5 \\
5.9 \pm 0.6 \\
1.0 \pm 0.2 \\
0.6 \pm 0.1\end{array}$ & $\begin{array}{c}59.4 \pm 4.7 \\
74.2 \pm 11.4 \\
47.3 \pm 5.3 \\
8.9 \pm 1.2\end{array}$ & $\begin{array}{l}6.1 \pm 0.6 \\
5.2 \pm 1.2 \\
4.5 \pm 0.6 \\
0.4 \pm 0.1\end{array}$ \\
\hline $\begin{array}{l}F 1 \\
F 2 \\
\text { F3 } \\
\text { F4 }\end{array}$ & \begin{tabular}{r}
\multicolumn{1}{l}{0} \\
$37.2 \pm 2.6$ \\
$1.1 \pm 0.8$ \\
$0.9 \pm 1.0$
\end{tabular} & $\begin{array}{l}0 \\
5.9 \pm 0.9 \\
0.1 \pm 0.1 \\
0.1 \pm 0.1\end{array}$ & $\begin{array}{l}0 \\
69.0 \pm 13.0 \\
3.2 \pm 0.7 \\
3.4 \pm 0.7\end{array}$ & $\begin{array}{l}0 \\
4.3 \pm 1.5 \\
0.2 \pm 0.2 \\
0.4 \pm 0.1\end{array}$ \\
\hline$R D X$ in $F 2^{(b)}$ & $41.6 \pm 3.0$ & $6.8 \pm 0.8$ & $88.9 \pm 44.3$ & $5.3 \pm 0.9$ \\
\hline
\end{tabular}

(a) Values are the average of 3 plants.

(b) Values determined by HPLC analysis of fraction F:2.

IABLE 3.11. PERCENTAGE OF RADIOLABEL IN VARIOUS CHEMICAL FRACTIONS OF WHEAT(a)

\begin{tabular}{|c|c|c|c|c|}
\hline \multirow[b]{2}{*}{ Fraction } & \multicolumn{2}{|c|}{ Day 1} & \multicolumn{2}{|c|}{ Day 7} \\
\hline & Shoot & Root & Shoot & Root \\
\hline $\begin{array}{l}\mathrm{HCl} \\
\mathrm{Et}_{2} \mathrm{O} \text { acid-neutral } \\
\mathrm{Aq}^{\mathrm{Base}} \\
\mathrm{Et}_{2} \mathrm{O} \text { base }\end{array}$ & $\begin{array}{c}17 \pm 4 \\
55 \pm 6 \\
9 \pm 2 \\
7 \pm 1\end{array}$ & $\begin{aligned} 21 & \pm 4 \\
56 & \pm 6 \\
10 & \pm 2 \\
6 & \pm 1\end{aligned}$ & $\begin{aligned} 35 & \pm 13 \\
43 & \pm 9 \\
28 & \pm 12 \\
5 & \pm 1\end{aligned}$ & $\begin{array}{r}35 \pm 5 \\
30 \pm 8 \\
25 \pm 2 \\
3 \pm 1\end{array}$ \\
\hline $\begin{array}{l}F 1 \\
F 2 \\
F 3 \\
F 4\end{array}$ & $\begin{array}{l}0 \\
54 \pm 9 \\
2 \pm 1 \\
1 \pm 2\end{array}$ & $\begin{aligned} & 0 \\
& 57 \pm 8 \\
& 1 \pm 0 \\
& 1 \pm 1\end{aligned}$ & $\begin{array}{l}0 \\
40 \pm 9 \\
2 \pm 0.3 \\
2 \pm 1\end{array}$ & $\begin{aligned} & 0 \\
& 25 \pm 7 \\
& 1 \pm 1 \\
& 2 \pm 0.3\end{aligned}$ \\
\hline Pellet & $6 \pm 2$ & $6 \pm 2$ & $14 \pm 5$ & $15 \pm 2$ \\
\hline
\end{tabular}


values reaching approximately $90 \mathrm{ppm}$ in the 7-day plants. The root tissue from both exposure periods contained about $5 \mathrm{ppm}$ RDX. The amounts of R.DX determined by radiocounting agree reasonably well with those obtained by HPLC analysis, indicating that all of the radiolabel contained in fraction F2 was speciated as RDX. The aqueous-base and F4 fractions collectively contained $10 \%$ of the total radiolabel in the 1 -day plants, wherc as these fractions contained $30 \%$ of the radiolabel in the 7-day plants. Again, metabolism of RDX seemed to be minimal in the 1-day plants; however, by 7 days considerable metabolism of RDX was evident.

Radiolabel contained in the pellet of wheat tissues did not follow the trend seen with the bush bean plants. The root and shoot tissues from each distinct exposure period displayed approximately equivalent amounts of immobilized residue contained within the pellet. Here, the 7 -day plants contained about $15 \%$ of the total radiolabel in the pellet, and tissues from the 1-day plants about half this value. This trend suggests that upon chronic exposure to RDX, cellular sequestering mechanisms are brought into play both in the shoot and root tissues of wheat.

The data for chemical fractionation of blando brome grown in hydroponic culture are presented in Tables 3.12 and 3.13. This species displayed trends similar to those previously described for bush bean and wheat; however, this species had an extremely high capacity to bioaccumulate RDX. As with the two previously described species, the root tissue from both 1 and 7-day plants showed little affinity for RDX, with concentrations remaining below $10 \mathrm{ppm}$. The shoot tissue from the 1-day blando brome plants contained about $40 \mathrm{ppm}$ RDX and that from the 7-day plants approximately $200 \mathrm{ppm}$, representing the highest concentration of RDX observed in plant tissues during the hydroponic studies. The concentration of $200 \mathrm{ppm}$ represents a bioconcentration of 40 times the concentration of RDX available from the hydroponic solutions. The highest percentage of total radiolabel in fraction F2 also was observed in blando brome. For the 7-day plants, the percentages of total radiolabel observed in fraction $\mathrm{F} 2$ were 50,40 , and $82 \%$ for bush bean, wheat, and blando brome, respectively. As with the other species, significant metabolism of RDX by blando brome was not observed until 7 days of exposure to RDX. The 1 -day plants contained $10 \%$ of the total radiolabel in the aqueous-base and $\mathrm{F} 4$ fractions, while the 7 -day plants contained $37 \%$ of the total radiolabel in these two fractions. 
IABLE 3.12. MICROGRAM RDX EQUIVALENTS IN CHEMICAL FRACTIONS OF BLANDO BROME(a)

\begin{tabular}{|c|c|c|c|c|}
\hline \multirow[b]{2}{*}{ Fraction } & \multicolumn{2}{|c|}{ Day 1} & \multicolumn{2}{|c|}{ Day 7} \\
\hline & Shoot & Root & Shoot & Root \\
\hline $\begin{array}{l}\mathrm{HCl} \\
\mathrm{Et}_{2} \mathrm{O} \text { acid-neutral }\end{array}$ & $\begin{array}{r}6.5 \pm 1.0 \\
36.5 \pm 2.1\end{array}$ & $\begin{array}{l}1.2 \pm 0.1 \\
4.7 \pm 0.4\end{array}$ & $\begin{array}{r}77.4 \pm 15.9 \\
183.0 \pm 76.5\end{array}$ & $\begin{array}{l}6.2 \pm 0.6 \\
8.0 \pm 2.6\end{array}$ \\
\hline $\begin{array}{l}\text { Aq Base } 2.4 \pm 0.7 \\
\mathrm{Et}_{2} \mathrm{O} \text { base }\end{array}$ & $\begin{array}{l}0.4 \pm 0.1 \\
4.7 \pm 0.5\end{array}$ & $\begin{array}{c}52.6 \pm 14.8 \\
0.4 \pm 0.5\end{array}$ & $\begin{array}{r}4.7 \pm 0.6 \\
23.7 \pm 9.3\end{array}$ & $0.9 \pm 0.2$ \\
\hline $\begin{array}{l}F 1 \\
F 2 \\
F 3 \\
F 4\end{array}$ & \begin{tabular}{r}
\multicolumn{1}{l}{0} \\
$37.4 \pm 2.4$ \\
$1.8 \pm 0.8$ \\
$0.5 \pm 0.3$
\end{tabular} & $\begin{array}{l}0 \\
4.5 \pm 0.6 \\
0.2 \pm 0.1 \\
0\end{array}$ & $\begin{aligned} 0.1 & \pm 0.2 \\
177.1 & \pm 80.9 \\
7.0 & \pm 4.9 \\
10.2 & \pm 2.6\end{aligned}$ & $\begin{array}{l}0 \\
7.1 \pm 2.6 \\
0.3 \pm 0.1 \\
0.9 \pm 0.2\end{array}$ \\
\hline$R D X$ in $F 2^{(b)}$ & $40.3 \pm 2.5$ & $5.59 \pm 0.6$ & $202.2 \pm 85.7$ & $8.04 \pm 3.2$ \\
\hline
\end{tabular}

(a) Values are the average of 3 plants.

(b) Values determined by HPLC analysis of fraction F2.

IABLE 3.13. PERCENTAGE OF RADIOLABEL IN VARIOUS CHEMICAL FRACTIONS OF BLANDO BROME(a)

\begin{tabular}{|c|c|c|c|c|}
\hline \multirow[b]{2}{*}{ Fraction } & \multicolumn{2}{|c|}{ Day 1} & \multicolumn{2}{|c|}{ Day 7} \\
\hline & Shoot & Root & Shoot & Root \\
\hline $\begin{array}{l}\mathrm{HCl} \\
\mathrm{Et}_{2} \mathrm{O} \text { acid-neutral } \\
\mathrm{Aq} \mathrm{Base} \\
\mathrm{Et}_{2} \mathrm{O} \text { base }\end{array}$ & $\begin{array}{c}14 \pm 3 \\
77 \pm 12 \\
9 \pm 4 \\
10 \pm 2\end{array}$ & $\begin{array}{c}14 \pm 2 \\
56 \pm 12 \\
5 \pm 1 \\
4 \pm 3\end{array}$ & $\begin{array}{l}37 \pm 5 \\
85 \pm 29 \\
32 \pm 9 \\
11 \pm 3\end{array}$ & $\begin{array}{l}29 \pm 6 \\
38 \pm 14 \\
22 \pm 6 \\
4 \pm 1\end{array}$ \\
\hline $\begin{array}{l}\text { F1 } \\
\text { F2 } \\
\text { F3 } \\
\text { F4 }\end{array}$ & $\begin{array}{l}0 \\
78 \pm 13 \\
4 \pm 2 \\
1 \pm 0\end{array}$ & $\begin{array}{l}0 \\
52 \pm 13 \\
2 \pm 1 \\
0\end{array}$ & $\begin{array}{l}0 \\
82 \pm 30 \\
3 \pm 2 \\
5 \pm 2\end{array}$ & $\begin{aligned} 0 & \\
34 & \pm 14 \\
1 & \pm 0.3 \\
4 & \pm 1\end{aligned}$ \\
\hline Pellet & $8 \pm 1$ & $4 \pm 1$ & $18 \pm 4$ & $12 \pm 1$ \\
\hline
\end{tabular}

(a) Values are the average of 3 plants. 
The radiolabel contained in the blando brome pellets showed increased values for longer exposures to RDX. The 7 . say exposure root pellets contained $12 \%$ of the total radiolabel, a value three times the percentage contained in the 1-day-exposure root pellets. The 7 -day blando brome shoot pellets contained about twice the percentage of radiolabel (18 vs. $8 \%$ ) of the 1-day-exposure pellets.

\subsubsection{Iransport Form of RDX in Xylem Exudates}

RDX was the sole metabolite isolated in fraction F2 from root and shoot tissues. Since the extraction procedure uses an acidic extraction step, the question arises as to whether the RDX is conjugated as noted for TNT (Cataldo et al., 1990). Figure 3.10 shows the transport form of bush bean exudates from hydroponically grown plants to be principally RDX $(96 \%)$, with a small fraction of RDX being present in a more polar form.

\subsection{ABSORPTION AND CHEMICAL FATE OE RDX IN MATURE PLANTS GROWN IN SOIL}

A major objective of the soil/plant-maturity studies was to assess to what extent and in what form RDX or its principal residues are accumulated, stored, or metabolized in soil-grown plants (bush bean, blando bromie, and wheat) at physiological maturity. We conducted preliminary studies to determine the maximum concentration of soil RIDX that could be used both in hydroponic and long-term soil studies without indicing adverse plant effects or toxicity. The plant-maturity studies were structured to elucidate accumulation and tissue-partitioning of

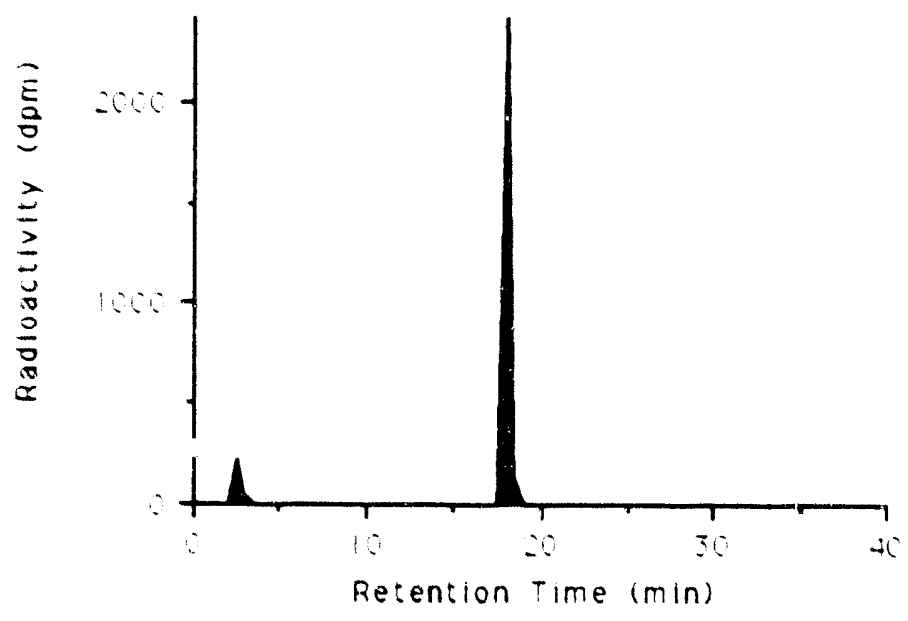

EIGURE 3.10. RADIOCHROMATOGRAM OF BUSH BEAN EXUDATES 
${ }^{14} \mathrm{C}$ derived from soil-aımended RDX. Plants were grown to physiological maturity, subsampled, and analyzed for total ${ }^{14} \mathrm{C}$ and fractionated for detailed chemical analyses. The following data sets contain treatments referred to as "chamber controls," which are unintented plants maintained in the same growth chambers as treatments. This is a standard procedure for dealing with ${ }^{14} \mathrm{C}$-labeled organics having the potential either for volatilization or oxidative decomposition. Actua! "treatment controls" were maintained in a separate growth chamber.

\subsubsection{Soil/Plant-Toxicity Studies}

To evaluate the potential phytotoxicity of RDX for both soil and hydroponic experiments, $400-g$ pots of Palouse and Cinebar soils were amended with RDX to final concentrations of 0 , 10,25 , or 50 ppm RDX. Pots of each soil and each concentration were then planted with either bush bean, wheat, or blando brome and the plants allowed to grow for 60 days, or until maturity. During this period the plants were observed for visible phytotoxic symptoms such as chlorosis, leaf curl or burn, or reduced growth. In all species at the 50-ppm concentrations, reductions in plant height of greater than $50 \%$ and chlorosis were observed, and at the 25-ppm concentration a growth reduction of $\sim 15 \%$ was indicated. As with TNT (Cataldo et al., 1990), no phytotoxic symptoms were visible in the 10-ppm plants. Therefore, the 10-ppm concentration was chosen for the future long-term soil-uptake studies. Short-term hydroponic studies were also conducted at solution concentrations of $10 \mathrm{ppm}$ or less.

Tables 3.14 and 3.15 provide biomass data for plants grown on 10-ppm RDX-amended soils and on treatment control soils not amended with RDX. Roots were washed free of soil for calculating mass-balance and assessing tissue distributions. With both wheat and blando brome, some growth reduction is noted for plants grown on Palouse and Burbank soils, but not on Cinebar. No phenotypic symptoms such as chlorosis were noted. Seed set and yield were either low or nonexistent for the grasses, although we do not believed this to be due to the presence of RDX.

In bush bean, the effects of RDX on biomass production were less evident (Table 3.15). Significant growth reductions were noted only for bean roots. No other tissues had weights less than the controls, and seed production in amended soils exceeded that in crintrols. Thus, while in wheat and blando brome the 10-ppm treatment level resulted in growth reductions, the absence of other symptoms such as chlorosis or leaf necrosis indicate that any toxicity from RDX would not likely affect the chemical fate of RDX. 
IABLE 3.14. AVERAGE FRESH WEIGHT OF WHEAT AND BLANDO BROME PLANTS GROWN FOR 60 DAYS IN SOILS AMENDED WITH $10 \mathrm{ppm}{ }^{14} \mathrm{C}$-RDX AND IN NON-AMENDED CONTROL SOILS

\begin{tabular}{|c|c|c|c|c|c|c|}
\hline \multirow[b]{2}{*}{ Species } & \multirow[b]{2}{*}{ Condition } & \multicolumn{5}{|c|}{ Plant Tissue } \\
\hline & & Soil & Shoot & Root & Se日d & Total \\
\hline & & \multicolumn{5}{|c|}{ Average Fresh Weight $\pm \mathrm{SD}^{(a)}$ or Variance ${ }^{(b)}$} \\
\hline \multicolumn{7}{|l|}{ WHEAT } \\
\hline \multicolumn{7}{|c|}{ RDX-Amended (a) } \\
\hline & & Cinebar & $5.41 \pm 1.38$ & $12.28 \pm 0.86$ & (c) & $17.69 \pm 1.94$ \\
\hline & & Palouse & $2.24 \pm 0.29$ & $5.38 \pm 0.99$ & - & $7.63 \pm 1.24$ \\
\hline & & Burbank & $2.63 \pm 0.04$ & $7.23 \pm 1.49$ & - & $9.86 \pm 1.79$ \\
\hline \multicolumn{7}{|c|}{ Treatment Control (b) } \\
\hline & & Cinebar & $6.70 \pm 0.21$ & $13.54 \pm 4.54$ & $\cdot$ & $21.10 \pm 3.12$ \\
\hline & & Palouse & $3.34 \pm 0.20$ & $9.17 \pm 1.44$ & $\cdot$ & $12.51 \pm 0.92$ \\
\hline & & Burbank & $3.76 \pm 0.65$ & $9.94 \pm 0.24$ & - & $13.7 \pm 0.41$ \\
\hline
\end{tabular}

BLANDO BROME

RDX-Amended (a)

$\begin{array}{llllr}\text { Cinebar } & 7.69 \pm 0.70 & 9.79 \pm 0.71 & 0.22 \pm 0.19 & 17.62 \pm 0.61 \\ \text { Palouse } & 3.13 \pm 0.40 & 5.99 \pm 0.93 & 0.06 \pm 0.02 & 9.16 \pm 0.99 \\ \text { Burbank } & 3.19 \pm 0.40 & 7.10 \pm 1.56 & 0.09 \pm 0.05 & 5.14 \pm 0.81\end{array}$

Treatment Control(b)

$\begin{array}{llrll}\text { Cinebar } & 8.92 \pm 0.14 & 16.41 \pm 6.17 & . & 23.38 \pm 5.98 \\ \text { Palouse } & 4.04 \pm 0.42 & 9.89 \pm 2.05 & - & 13.93 \pm 2.48 \\ \text { Burbank } & 3.69 \pm 0.05 & 12.60 \pm 1.27 & 0.12 \pm 0.00 & 10.26 \pm 0.69\end{array}$
(a) $n=9$.
(b) $n=6$.
(c) Significant $(P \leq 0.1)$ according to one-tailed t-Test. 
IABLE 3.15. AVERAGE FRESH WEIGHT OF BUSH BEAN PLANTS GROWN FOR 60 DAYS IN SOILS AMENDED WITH 10 PPM ${ }^{14} \mathrm{C}$-RDX AND IN NON-AMENDED CONTROL SOILS

\begin{tabular}{|c|c|c|c|c|c|c|}
\hline \multirow[b]{2}{*}{ Condition/Soil } & \multicolumn{6}{|c|}{ Plant Tissue } \\
\hline & Leaf & Stem & Pod & Seed & Root & Total \\
\hline & \multicolumn{6}{|c|}{ Average Fresh Weight $(g) . \pm S D^{(a)}$ or variance ${ }^{(b)}$} \\
\hline \multicolumn{7}{|c|}{ RDX-Amended (a) } \\
\hline Cinebar & $8.63 \pm 2.45$ & $4.02 \pm 0.23$ & $10.28 \pm 0.91$ & $1.71 \pm 0.27$ & $3.95 \pm 0.44$ & $27.54 \pm 2.69$ \\
\hline Palouse & $5.72 \pm 1.41$ & $2.35 \pm 0.26$ & $6.95 \pm 1.78$ & $1.19 \pm 0.81$ & $4.97 \pm 1.71$ & $17.6 \pm 3.23$ \\
\hline Burbank & $5.27 \pm 0.84$ & $2.33 \pm 0.28$ & $5.29 \pm 0.93$ & $0.68 \pm 0.21$ & $2.22 \pm 0.32$ & $15.98 \pm 2.10$ \\
\hline \multicolumn{7}{|c|}{ Treatmont Control(b) } \\
\hline Cinebar & $6.21 \pm 2.65$ & $4.08 \pm 0.62$ & $7.46 \pm 1.01$ & $0.23 \pm 0.01$ & $9.06 \pm 3.37$ & $27.05 \pm 4.38$ \\
\hline Palouse & $5.80 \pm 0.40$ & $2.66 \pm 0.16$ & $3.61 \pm 1.43$ & $0.23 \pm 0.14$ & $5.25 \pm 1.16$ & $16.79 \pm 3.73$ \\
\hline Burbank & $4.27 \pm 1.06$ & $2.51 \pm 0.19$ & $2.35 \pm 0.21$ & $0.08 \pm 0.01$ & $4.58 \pm 2.31$ & $15.78 \pm 5.06$ \\
\hline
\end{tabular}

(a) $n=5$.

(b) $n=2$.

\subsubsection{Leng-Term Partitioning of TNT Within the Plant}

The accumulation of RDX by bush bean plants grown on soils containing 10-ppm ${ }^{14} \mathrm{C}-\mathrm{RDX}$, based on RDX activity equivalents, is quite high and is inversely proportional to soil organic matter and CEC (Table 3.16). Tissue concentration patterns indicate that RDX is particularly mobile following root uptake. For all soils, the order of increasing RDX concentration is seed $>$ leaf $\geq$ stem $>$ roo $\geq$ pod. Plants grown on the low-CEC and loworganic-matter Burbank soil showed leaf and seed concentrations of 200 and 600 ppm RDX equivalents while roots contained only $75 \mathrm{ppm}$. This distribution pattern indicates that unlike for TNT (Cataldo et al., 1990), the root has only a limited storage capacity for RDX.

Chamber controls (Table 3.16) showed limited ${ }^{14} \mathrm{C}$-activity. The activity likely resulted from the uptake of ${ }^{14} \mathrm{CO}_{2}$ from mineralization of radiolabeled $\mathrm{RDX}$ by plant roots and soils, as was seen in the volatilization studies. Treatment controls, not contained within the same growth chamber, showed no elevated background activity. 
IABLE3.16. SPECIFIC UPTAKE ( $\mu$ g RDX equivalents/g Fresh Weight $\left.\times 10^{2(a)}\right)$ FOR PLANT TISSUES OF BUSH BEAN GROWN FOR 60 DAYS IN SOILS AMENDED WITH $10 \mathrm{ppm}{ }^{14} \mathrm{C}$-RDX AND FOR CHAMBER AND TREATMENT CONTROLS

\begin{tabular}{llcccc}
\hline \multirow{3}{*}{ Condition/Soil } & \multicolumn{4}{c}{ Plant Tissue } & \\
\cline { 2 - 5 } & Leaf & Stem & Pod & Seed & Root \\
\hline
\end{tabular}

$\mu g$ RDX equivalents/g Fresh Weight $\pm S D$

RDX-Amended (b)

$\begin{array}{lccccc}\text { Cinebar } & 22.43 \pm 7.50 & 19.44 \pm 5.61 & 10.52 \pm 2.63 & 39.46 \pm 15.78 & 8.13 \pm 1.09 \\ \text { Palouse } & 119.37 \pm 34.74 & 98.10 \pm 32.19 & 33.37 \pm 9.76 & 300.77 \pm 169.78 & 49.12 \pm 3.92 \\ \text { Burbank } & 216.74 \pm 40.89 & 186.92 \pm 38.09 & 44.54 \pm 17.51 & 602.57 \pm 256.64 & 75.01 \pm 11.43\end{array}$

Chamber Control $(c)$

$\begin{array}{llllll}\text { Cinebar } & 0.07 \pm 0.01 & 0.07 \pm 0.002 & 0.02 \pm 0.004 & 0.06 \pm 0.06 & 0.03 \pm 0.01 \\ \text { Palouse } & 0.07 \pm 0.01 & 0.08 \pm 0.002 & 0.03 \pm 0.005 & 0.00 & 0.03 \pm 0.008 \\ \text { Burbank } & 0.107 \pm 0.007 & 0.10 \pm 0.011 & 0.04 \pm 0.107 & 0.00 & 0.02 \pm 0.01\end{array}$

Treatment Control(d)

$\begin{array}{llllll}\text { Cinebar } & 0.00 & 0.00 & 0.00 & 0.00 & 0.00 \\ \text { Palouse } & 0.00 & 0.00 & 0.00 & 0.00 & 0.00 \\ \text { Burbank } & 0.00 & 0.00 & 0.00 & 0.00 & 0.00\end{array}$

\footnotetext{
(a) Derived from specific activity.

(b) Plants grown in RDX-amended suil, $n=9$.

(c) Plants grown in non-amended soil in same chamber as RDX plants, $n=6$.

(d) Plants grown in non-amended soil in different chamber, $n=6$.
}

Accumulation patterns for the two grass species (Table 3.17) are generally similar to that observed for bush bean. In both wheat and blando brome, the roots contain only a fraction of the accumulated RDX activity (equivalent to 7 to $45 \mathrm{ppm}$ ), while the leaves contain 40 to 560 ppm RDX equivalents. As with bush bean, tissue concentrations of RDX are inversely proportional to soil organic matter and CEC.

The uptake rates, plant mobility, and accumulation rates for RDX in leaves and seed are substantially greater than those for TNT. The behavior of RDX may present special problems with respect to food-chain transport and effects of herbivores ingesting vegetation growing on RDX-contaminated soils.

\subsubsection{Chemistry of RDX in Mature Plants}

The results of the chemical fractionation and analysis of mature bush bean plants 
IABLE 3.17. SPECIFIC UPTAKE ( $\mu$ g RDX equivalents/g Fresh Weight $\times 10^{2(a)}$ ) FOR PLANT TISSUES OF WHEAT AND BLANDO BROME GROWN FOR 60 DAYS IN SOILS AMENDED WITH $10 \mathrm{ppm}{ }^{14} \mathrm{C}$-RDX AND FOR CHAMBER AND TREATMENT CONTROLS

\begin{tabular}{|c|c|c|c|c|c|}
\hline \multirow{3}{*}{ Species } & \multirow{3}{*}{ Condition } & \multicolumn{4}{|c|}{ Plant Tissue } \\
\hline & & Soil & Shoot & Seod & Root \\
\hline & & \multicolumn{4}{|c|}{$\mu \mathrm{g} R D X$ equivalents/g Fresh Weight $(a) \pm S D$} \\
\hline
\end{tabular}

WHEAT

RDX-Amended (b)

Chamber Control(b)

$\begin{array}{lccc}\text { Cinebar } & 75.72 \pm 23.22 & - & 17.92 \pm 3.70 \\ \text { Palouse } & 422.70 \pm 126.67 & - & 45.10 \pm 8.94 \\ \text { Burbank } & 549.88 \pm 140.93 & - & 40.11 \pm 9.62\end{array}$

$\begin{array}{llll}\text { Cinebar } & 0.01 \pm 0.001 & - & 0.03 \pm 0.00 \\ \text { Palouse } & 0.10 \pm 0.002 & - & 0.03 \pm 0.005 \\ \text { Burbank } & 0.12 \pm 0.002 & - & 0.03 \pm 0.004\end{array}$

\section{BLANDO BROME}

RDX-Amended (c)

$\begin{array}{lccr}\text { Cinebar } & 43.76 \pm 9.95 & 40.00 \pm 5.42 & 7.64 \pm 2.03 \\ \text { Palouse } & 545.45 \pm 155.36 & 257.96 \pm 47.72 & 21.84 \pm 3.78 \\ \text { Burbank } & 564.46 \pm 128.15 & 317.06 \pm 122.19 & 27.95 \pm 5.51\end{array}$

Chamber Control(b)

$\begin{array}{llll}\text { Cinebar } & 0.07 \pm 0.006 & 0.16 \pm 0.09 & 0.02 \pm 0.01 \\ \text { Palouse } & 0.12 \pm 0.01 & 0.26 \pm 0.04 & 0.03 \pm 0.004 \\ \text { Burbank } & 0.13 \pm 0.005 & 0.26 \pm 0.02 & 0.03 \pm 0.02\end{array}$

\footnotetext{
(a) Derived from specific activity.

(b) $n=9$.

(c) $n=6$.
}

grown in the three soils are shown in Tables 3.18 and 3.19. The values in these tables are based on the analysis of one plant, and were used to verify the behavior observed in the hydroponic studies. Table 3.18 summarizes the quantities of RDX ( $\mu \mathrm{g}$ RDX equivalents) contained in the various fractions, whereas Table 3.19 presents the percentage of total radiolabel contained in each of the fractions. Table 3.20 presents the results of analysis for bush bean pods. Unfortunately, a sufficient quantity of bush bean seeds were not available to allow for chemical fractionation and analysis; however, seed tissue was oxidized to provide data on the total amount of radiolabel contained in this tissue. 
IABLE 3.18. MICROGRAM RDX EQUIVALENTS IN CHEMICAL FRACTIONS OF MATURE BUSH BEAN(a)

\begin{tabular}{|c|c|c|c|c|c|c|}
\hline \multirow[b]{2}{*}{ Fraction } & \multicolumn{2}{|c|}{ Burbank } & \multicolumn{2}{|c|}{ Palouse } & \multicolumn{2}{|c|}{ Cinebar } \\
\hline & Leaves & Stem & Leaves & Stem & Leaves & Stem \\
\hline $\begin{array}{l}\mathrm{HCl} \\
\mathrm{Et}_{2} \mathrm{O} \text { acid-neutral } \\
\mathrm{Aq} \text { Base } \\
\mathrm{Et}_{2} \mathrm{O} \text { base }\end{array}$ & $\begin{array}{r}66.4 \\
52.7 \\
57.0 \\
6.7\end{array}$ & $\begin{array}{r}74.9 \\
8.1 \\
69.3 \\
1.5\end{array}$ & $\begin{array}{r}44.4 \\
24.6 \\
38.6 \\
3.0\end{array}$ & $\begin{array}{r}22.0 \\
4.5 \\
19.9 \\
0.7\end{array}$ & $\begin{array}{l}6.0 \\
3.5 \\
5.2 \\
0.3\end{array}$ & $\begin{array}{r}6.0 \\
11.7 \\
4.7 \\
0.2\end{array}$ \\
\hline $\begin{array}{l}F 1 \\
F 2 \\
F 3 \\
F 4\end{array}$ & $\begin{array}{r}2.3 \\
39.6 \\
0.8 \\
4.9\end{array}$ & $\begin{array}{l}0 \\
2.9 \\
0.1 \\
2.5\end{array}$ & $\begin{array}{r}0.7 \\
14.4 \\
0.7 \\
4.3\end{array}$ & $\begin{array}{l}0 \\
2.7 \\
0.1 \\
0.8\end{array}$ & $\begin{array}{l}0.1 \\
1.7 \\
0.1 \\
0.6\end{array}$ & $\begin{array}{l}0 \\
1.0 \\
0 \\
0.4\end{array}$ \\
\hline Pellet & 26.5 & 55.6 & 18.5 & 18.8 & 2.9 & 6.5 \\
\hline $\mathrm{RDX}$ in $\mathrm{F} 2^{(\mathrm{b})}$ & 28.9 & 2.17 & 9.5 & 2.7 & 0.9 & 1.0 \\
\hline
\end{tabular}

(a) Values based on the analysis of 1 plant.

(b) Values determined by HPLC analysis of fraction F2.

IABLE 3.19. PERCENTAGE OF TOTAL RADIOACTIVITY, BASED ON OXIDATION, IN CHEMICAL FRACTIONS OF MATURE BUSH BEAN PLANTS GROWN IN THREE SOIL TYPES(a)

\begin{tabular}{|c|c|c|c|c|c|c|}
\hline \multirow[b]{2}{*}{ Fraction } & \multicolumn{2}{|c|}{ Burbank } & \multicolumn{2}{|c|}{ Palouse } & \multicolumn{2}{|c|}{ Cinebar } \\
\hline & Leaves & Stem & Leaves & Stem & Leaves & Stem \\
\hline $\mathrm{HCl}$ & 35 & 43 & 30 & 31 & 22 & 47 \\
\hline $\mathrm{Et}_{2} \mathrm{O}$ acid-neutral & 28 & 5 & 17 & 6 & 13 & 14 \\
\hline Aq̣ Base & 30 & 40 & 26 & 28 & 19 & 37 \\
\hline $\mathrm{Et}_{2} \mathrm{O}$ base & 4 & 1 & 2 & 1 & 1 & 2 \\
\hline$F 1$ & 1 & 0 & 0 & 0 & 0 & 0 \\
\hline F2 & 21 & 2 & 10 & 4 & 6 & 8 \\
\hline F3 & 0 & 0 & 0 & 0 & 0 & 0 \\
\hline $\mathrm{F} 4$ & 3 & 1 & 3 & 1 & 2 & 3 \\
\hline Pellet & 14 & 32 & 12 & 27 & 11 & 51 \\
\hline
\end{tabular}

(a) Values based on the analysis of 1 plani. 
IABLE 3.20. MICROGRAM RDX EQUIVALENTS AND PERCENTAGE OF TOTAL RADIOLABEL CONTAINED IN VARIOUS CHEMICAL FRACTIONS OF MATURE BUSH BEAN PODS(a)

\begin{tabular}{|c|c|c|c|c|c|c|}
\hline \multirow[b]{3}{*}{ Fraction } & \multicolumn{6}{|c|}{ Soil } \\
\hline & \multicolumn{2}{|c|}{ Burbank } & \multicolumn{2}{|c|}{ Palouse } & \multicolumn{2}{|c|}{ Cinebar } \\
\hline & $\mu \mathrm{g} R \mathrm{RD}$ & $\%$ total & $\mu \mathrm{g} \mathrm{RDX}$ & $\%$ total & $\mu \mathrm{g} R D X$ & $\%$ total \\
\hline $\begin{array}{l}\mathrm{HCl} \\
\mathrm{Et}_{2} \mathrm{O} \text { acid-neutral } \\
\mathrm{Aq} \mathrm{Base} \\
\mathrm{Et}_{2} \mathrm{O} \text { base }\end{array}$ & $\begin{array}{r}25.2 \\
2.8 \\
23.7 \\
0.7\end{array}$ & $\begin{array}{r}55.5 \\
6.2 \\
52.2 \\
1.5\end{array}$ & $\begin{array}{r}20.4 \\
3.8 \\
18.6 \\
0.6\end{array}$ & $\begin{array}{c}45.7 \\
8.4 \\
41.7 \\
1.34\end{array}$ & $\begin{array}{l}4.0 \\
0.8 \\
3.6 \\
0.1\end{array}$ & $\begin{array}{r}61.1 \\
12.8 \\
54.9 \\
1.9\end{array}$ \\
\hline $\begin{array}{l}F 1 \\
F 2 \\
F 3 \\
F 4\end{array}$ & $\begin{array}{l}0 \\
1.3 \\
0.1 \\
0.5\end{array}$ & $\begin{array}{l}0 \\
2.9 \\
0.1 \\
1.2\end{array}$ & $\begin{array}{l}0 \\
2.0 \\
0.1 \\
0.5\end{array}$ & $\begin{array}{l}0 \\
4.5 \\
0.2 \\
1.2\end{array}$ & $\begin{array}{l}0 \\
0.7 \\
0 \\
0.1\end{array}$ & $\begin{array}{l}0 \\
10.2 \\
0 \\
1.4\end{array}$ \\
\hline Pellet & 5.3 & 11.6 & 4.9 & 11.0 & 0.7 & 10.8 \\
\hline $\mathrm{RDX}$ in F2 (b) & 1.5 & ---- & 2.0 & $\ldots$ & 0.7 & $-\cdots$ \\
\hline
\end{tabular}

(a) Values based on the analysis of 1 plant.

(b) Values determined by HPLC analysis of fraction F2.

From the data presented in Tables 3.18 and 3.19, it is clear that RDX was present in the stem and leaf tissues of mature plants. Plants grown in Burbank soil accumulated the largest quantity of RDX, with Palouse-grown plants containing intermediate amounts and Cinebargrown plants contained the lowest quantity. Leaf tissue from the Burbank-grown bush beans contained about 30 ppm RDX in fraction F2. Since the soils contained only 10 ppm RDX, the plants were able to bioconcentrate RDX from this soil. Tissues from Palouse and Cinebar soils showed the presence of RDX, but not to the extent seen in plants grown in Burbank soil. Significant metabolism of RDX was seen in the mature bush bean tissues. The ether nonextractables (aqueous-base fractions) contained considerably higher percentages of the total radiolabel than the corresponding F2 fractions (Table 3.19).

An interesting trend regarding the percentage of radiolabel contained in the pellets, first noticed during the hydroponic studies of bush beans, was also seen in the mature bush bean plants. As for the bush bean plants grown in hydroponic culture for 7 days, in all soil-grown plants the stem pellets contained a higher percentage of radiolabel than did leaf tissue (Table 3.19). also contained significantly higher amounts of radiolabel than the leaf tissue pellets. These data may indicate that immobilization and sequestration of RDX occurs primarily in the root and stem tissue, with less immobilization occurring in the leaf tissue. 
The bush bean pods (Table 3.20) contained small quantities of RDX ( $\leq 2 \mathrm{ppm}$ ). Most of the radiolabel contained in these tissues had undergone extensive metabolic alteration and appeared in the nonextractable aqueous-base fraction. The distribution of RDX in the pod pellets more closely resembled that of the leaf tissue than the stem tissue.

Radiochromatography previously has been used in analyzing plants grown in hydroponic solution to demonstrate that speciation of radiolabel within fraction F2 was due to chemically unaltered RDX. It was essential to repeat radiochromatographic studies of F2 fractions isolated from mature plants, since chronic exposure and accumulation of RDX may significantly alter metabolic processes.

Figures 3.11 and 3.12 present radiochromatograms derived from bush bean plants grown in Palouse soil. These plants were chosen for further radiochromatographic studies because the Palouse soil represents a typical agricultural soil, containing intermediate amounts of total orgaric carbon. Radiocarbon profiles from bush bean leaf (Figure 3.11) and pod (Figure 3.12) showed the presence of RDX only and a lack of RDX metabolites.

Results of the fractionation and analysis of the mature monocotyledons, wheat and blando brome, are presented in Tables 3.21 and 3.22. Table 3.21 gives the microgram RDX equivalents and HPLC analysis results, while Table 3.22 summarizes the percentage of total radiolabel distribution. The results in Table 3.21 indicated an enormous ability of both wheat

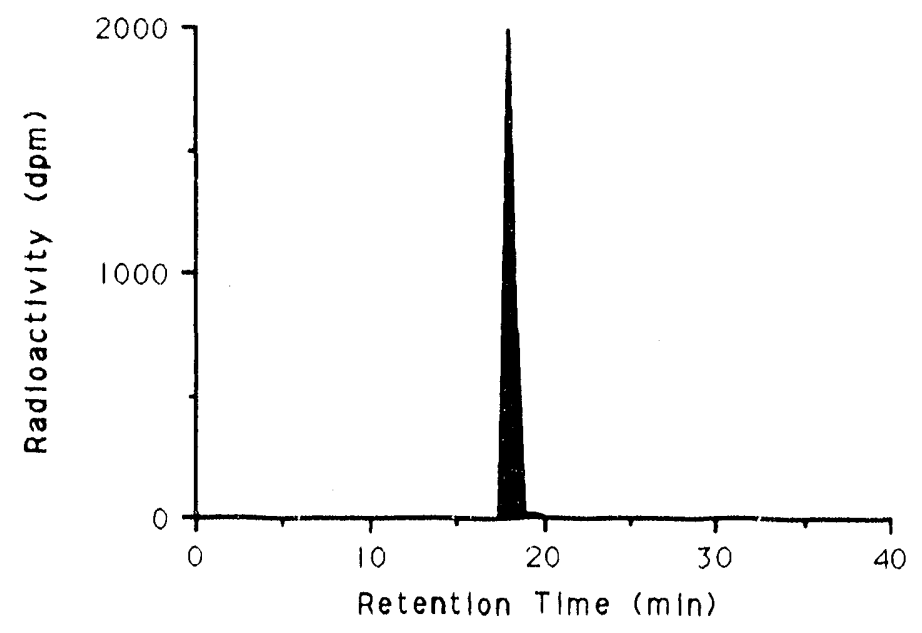

EIGURE 3.11. RADIOCHROMATOGRAM OF FRACTION F2 FROM MATURE BUSH BEAN LEAF TISSUE 


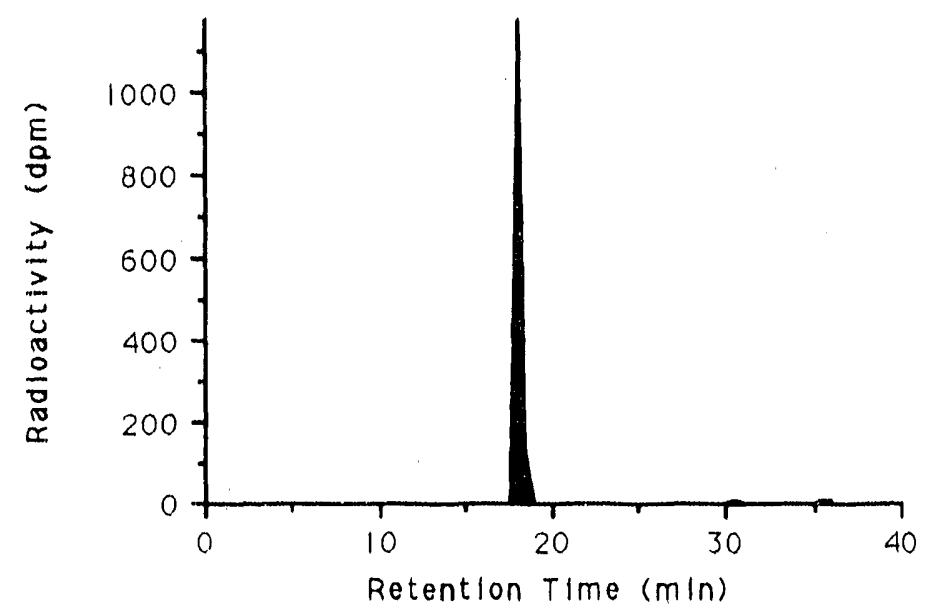

EIGURE 3.12. RADIOCHROMATOGRAM OF FRACTION F2 FROM MATURE BUSH BEAN POD TISSUE

IABLE 3.21. MICROGRAM RDX EQUIVALENTS IN CHEMICAL FRACTIONS OF MATURE WHEAT AND BLANDO BROME(a)

\begin{tabular}{|c|c|c|c|c|c|c|}
\hline \multirow[b]{4}{*}{ Fraction } & \multicolumn{6}{|c|}{ Soil } \\
\hline & \multicolumn{2}{|c|}{ Burbank } & \multicolumn{2}{|c|}{ Palouse } & \multicolumn{2}{|c|}{ Cinebar } \\
\hline & & & \multicolumn{2}{|c|}{ Species } & \multirow[b]{2}{*}{ Blando Brome } & \multirow[b]{2}{*}{ Wheat } \\
\hline & Blando Brome & Wheat & Blando Brome & Wheat & & \\
\hline $\mathrm{HCl}$ & 92.6 & 126.3 & 70.8 & $\uparrow 16.1$ & 13.2 & 169 \\
\hline $\mathrm{Et}_{2} \mathrm{O}$ acid-neutral & 164.4 & 136.0 & 216.1 & 123.8 & 14.5 & 5.0 \\
\hline Aq Base & 60.9 & 100 & 41.5 & 94.2 & 10.4 & 15.7 \\
\hline $\mathrm{Et}_{2} \mathrm{O}$ base & 31.4 & 12.4 & 29.5 & 15.8 & 2.3 & 0.5 \\
\hline $\mathrm{F} 1$ & 0 & 0.1 & 0 & 0 & 0 & 0 \\
\hline F2 & 240.4 & 122.6 & 210.6 & 109.1 & 14.2 & 2.7 \\
\hline F3 & 5.3 & 2.4 & 4.1 & 2.2 & 0.5 & 0.1 \\
\hline $\mathrm{F} 4$ & 7.1 & 14.4 & 7.1 & 11.7 & 0.9 & 1.5 \\
\hline Pellet & 75.8 & 105.2 & 60.3 & 87.9 & 0.9 & 8.77 \\
\hline $\mathrm{RDX}$ in $\mathrm{F}_{2}{ }^{(\mathrm{b})}$ & 282.7 & 114.7 & 226.3 & 175.1 & 12.0 & 3.3 \\
\hline
\end{tabular}

(a) Values based on the analysis of 1 plant.

(b) Values determined by HPLC analysis of fraction F2. 
TABLE 3.22. PERCENTAGE OF TOTAL RADIOACTIVITY, BASED ON OXIDATION, IN CHEMICAL FRACTIONS OF MATURE WHEAT AND BLANDO BROME GROWN IN THREE SOIL TYPES(a)

\begin{tabular}{|c|c|c|c|c|c|c|}
\hline \multirow[b]{3}{*}{ Fraction } & \multicolumn{6}{|c|}{ Soil } \\
\hline & \multicolumn{2}{|c|}{ Burbank } & \multicolumn{2}{|c|}{ Palouse } & \multicolumn{2}{|c|}{ Cinebar } \\
\hline & Blando Brome & Wheat & Blando Brome & Wheat & Blando Brome & Wheat \\
\hline $\mathrm{HCl}$ & 20 & 19 & 11 & 31 & 28 & 40 \\
\hline $\mathrm{Et}_{2} \mathrm{O}$ acid-neutral & 36 & 21 & 32 & 33 & 31 & 12 \\
\hline Aq Base & 13 & 15 & 6 & 25 & 22 & 37 \\
\hline $\mathrm{Et}_{2} \mathrm{O}$ base & 7 & 2 & 4 & 4 & 5 & 1 \\
\hline F1 & 0 & 0 & 0 & 0 & 0 & 0 \\
\hline $\mathrm{F} 2$ & 53 & 19 & 31 & 29 & 30 & 6 \\
\hline F3 & 1 & 0 & 1 & 1 & 1 & 0 \\
\hline $\mathrm{F} 4$ & 2 & 2 & 1 & 3 & 2 & 3 \\
\hline Pellet & 17 & 16 & 9 & 23 & 17 & 21 \\
\hline
\end{tabular}

(a) Values based on the analysis of 1 plant.

and blando brome to bioconcentrate RDX. Of the two species, blando brome showed the highest amount of bioacsumulation. Shoot concentrations of RDX in blando brome were 283, 226, and $12 \mathrm{ppm}$ for Burbank, Palouse, and Cinebar soils, respectively. RDX concentrations for fraction F2 obtained by radiocounting ( $240 \mathrm{ppm})$ agree reasonably well with values obtained by HPLC analysis (283 ppm). Radiochromatographic analysis of the F2 fraction of blando brome is shown in Figure 3.13. RDX was the only radiocarbon-containing species in this fraction. The concentration of RDX observed in blando brome grown in Burbank soil was the highest observed throughout the mature-plant RDX studies. For blando brome, as for the mature bush bean, RDX was most available for uptake from Burbank soil, slightly less available from Palouse soil, and far less available from Cinebar. The RDX metabolism of blando brome piants was drastically diminished in comparison with the bush beans. For blando brome, the percentage of total radiolabel contained in fraction F2 was always higher than that contained in the aqueous-base fractions. This trend suggests a lower metabolic turnover of RDX than was seen in the mature bush beans. The percentage of radiolabel localized in fraction $\mathrm{F} 2$ was 53,31 , and $30 \%$ of the total radiolabel for plants grown in Burbank, Palouse, and Cinebar soils, respectively (Table 3.22). The amount of radiolabel contained in the blando brome pellets was about the same or lower than amounts observed in the 7-day blando brome hydroponic plants. 


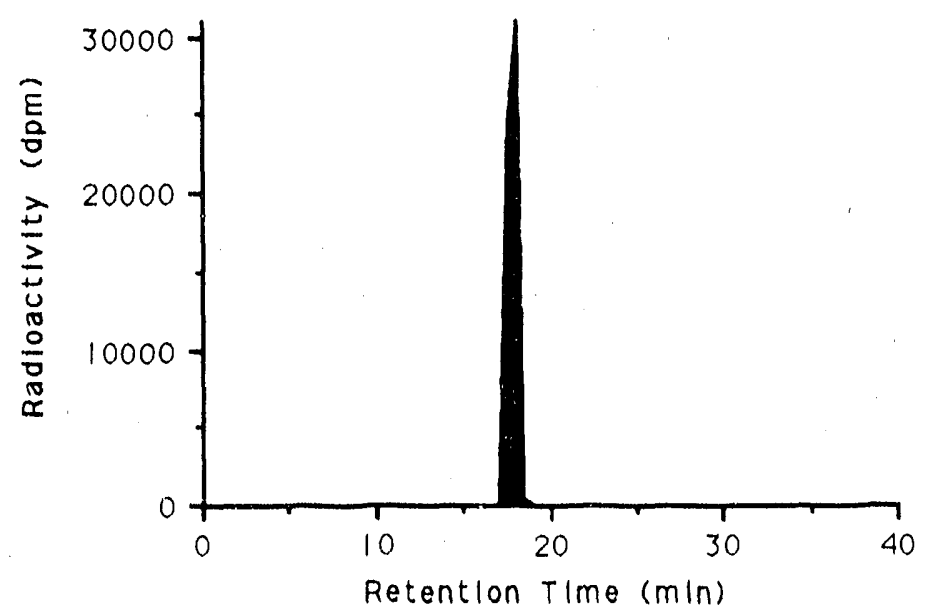

EIGURE 3.13. RADIOCHROMATOGRAM OF FRACTION F2 FROM MATURE BLANDO BROME SHOOT TISSUE

Mature wheat plants displayed a distribution of radiolabel similar to distributions observed for mature blando brome. The concentrations of RDX in the shoot tissues, as determined by HPLC, were 115, 175, and 3 ppm for plants grown in Burbank, Palouse and Cinebar soil, respectively (Table 3.21). Only a small relative amount of RDX was found in shoot tissue of Cinebar-grown plants. Close agreement between RDX concentrations determined by radiocounting and HPLC analysis again suggested that all of the activity in fraction F2 was due to RDX. To obtain further evidence of a lack of metabolites in fraction F2, a radiochromatogram of this fraction for Palouse-grown shoot tissue was performed. The radiocarbon profile is shown in Figure 3.14. As was verified for the other two species, ${ }^{14} \mathrm{C}$ RDX was the only peak observed in the F2 fraction. Although blando brome grown in Burbank soil contained the highest concentration of RDX (283 ppm), Palouse-grown wheat shoots had the highest concentrations of RDX (226 ppm). The metabolic conversion of RDX appeared to be slightly higher in wheat, as evidenced by the higher percentage of radiolabel in the aqueous-base fraction and the lower percentage in fraction F2 of the wheat plants. The metabolism of RDX in both monocotyledon species grown in Burbank or Palouse soil in general was less than that observed in the bush bean plants grown in the same soils. RDX uptake from Cinebar soil was very low compared with the other two soils. The RDX metabolism of plants grown in Cinebar soil, based on the percentage of radiolabel contained in the aqueous-base fraction, was equivalent for bush bean stem and wheat shoots $(37 \%)$. Lesser but similar amounts were found in bush bean leaves and blando brome shoots ( 19 and $22 \%)$. 


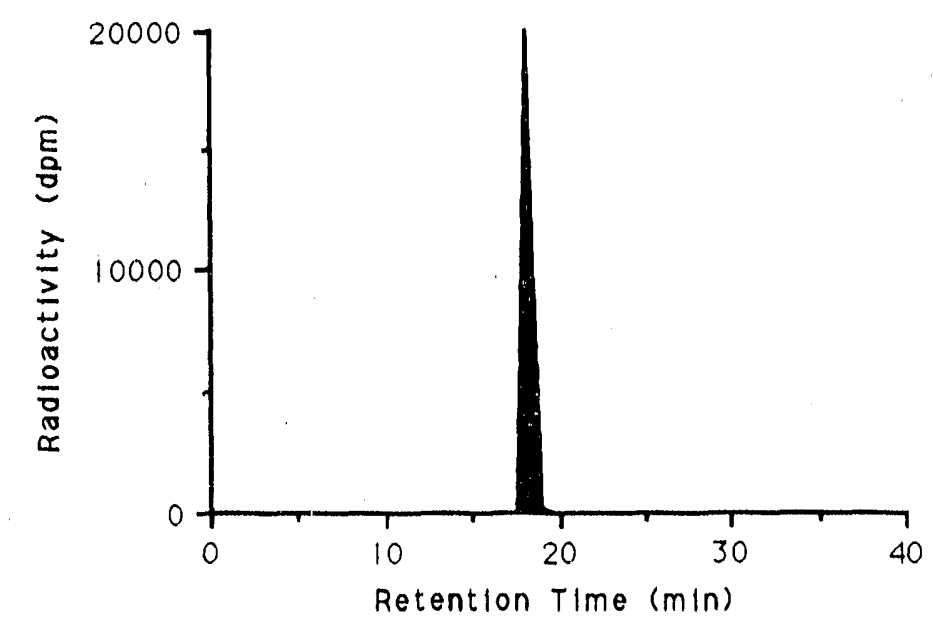

\section{EIGURE 3.14. RADIOCHROMATOGRAM OF FRACTION F2 FROM MATURE WHEAT} SHOOT TISSUE

\subsection{BDX BEHAVIOR IN SOUL.AND RELATIVE PLANT AVALLABULTY}

From 77 to $92 \%$ of the RDX amended to soil (Burbank and Cinebar, respectively) is extractable with solvent after 2 months of incubation (Table 3.1). No evidence exists from these short-term studies to indicate any detectable chemical transformations of RDX. A small fraction of the RDX added to soil ( 0.5 to $2 \%$ ) remains firmly bound to soils. Figure 3.15 shows the relationships between RDX solvent extractability and soil organic matter and CEC. The extent of both extractability and sorption appears to be inversely related to soil CEC and organic matter. However, it is difficult to assign a mechanism by which RDX can be sorbed either to cation-exchange sites or organic matter, since RDX is nonpolar. Yet this sorption phenomenon does occur with RDX, and it was much more pronounced for TNT (Cataldo et al., 1990, Table 3.2), where extractability ranged from 37 to $60 \%$ after 60 days of incubation.

Whatever is the phenomenon controlling RDX solubility in soil, it has a direct influence on the availability and tissue concentrations of RDX in plants. The tissue-accumulation and concentration patterns shown in Tables 3.16 and 3.17 clearly demonstrate that RDX is highly mobile within the plant and that the extent of uptake is characteristic of soil type. Figures 3.16 through 3.18 plot shoot concentrations of RDX in the three plants against soil organic matter and CEC. Shoot concentrations of RDX are based on all shoot tissues following harvest of mature plants grown on Burbank, Palouse and Cinebar soils. Overall, correlations of plant concentrations with either $\mathrm{CEC}$ or soil organic matter, while showing a distinct inverse relationship, are not consistent. For bush bean and wheat, RDX accumulation correlates with 
CEC $\left(R^{2}>0.98\right)$, while in blando brome RDX accumulation correlates best with organic matter content $\left(R^{2}=0.98\right)$.

An important aspect of the soil/plant-maturity studies is the extent to which RDX is removed from the soils. Soils were amended with $10 \mathrm{ppm}$ RDX, $4000 \mu \mathrm{g} / 400 \mathrm{~g}$ pot. One harvest of bush bean grown on Burbank soil removed $>2200 \mu \mathrm{g}$ of RDX, or $55 \%$ of the RDX amended to soil. Similarly, the bush bean removed $37 \%$ from Palouse, $11 \%$ from the highCEC, high organic-matter Cinebar soil. Blando brome rernoved $1800 \mu \mathrm{g}$, or $45 \%$, of the RDX from Burbank soil, while wheat removed $52 \%$. While this would suggest that contaminated sites can be planted and harvested to effectively recover dispersed contamination, these elevated tissue concentrations could present a prominent food-chain contamination route for RDX. 


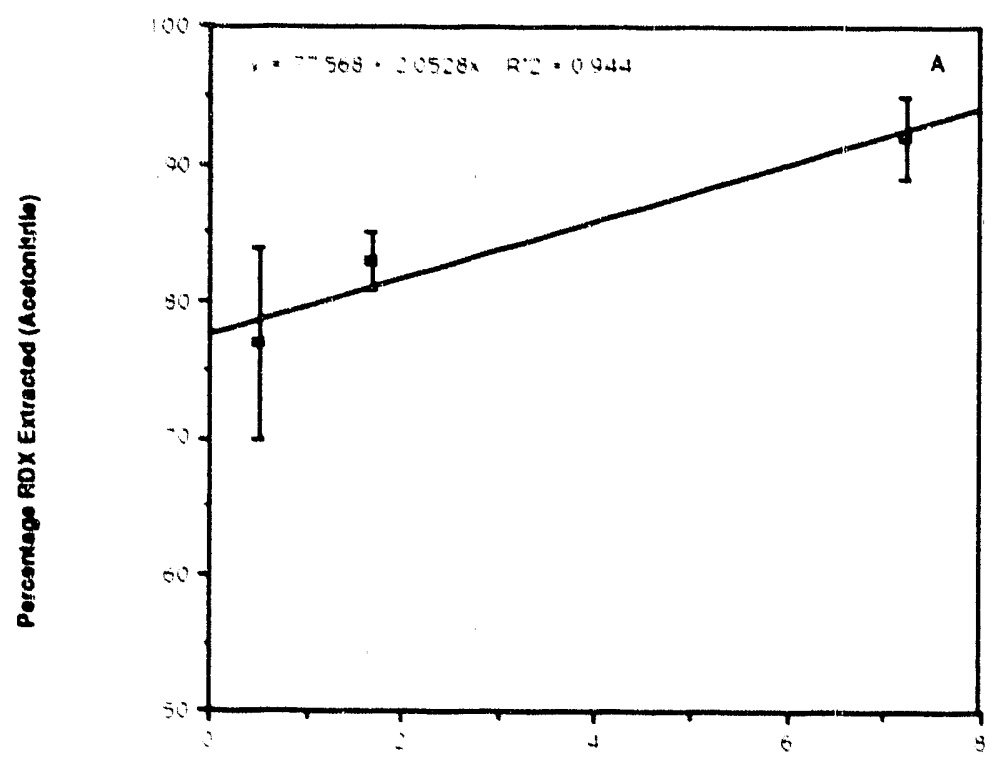

Soll Organic Matter (x)

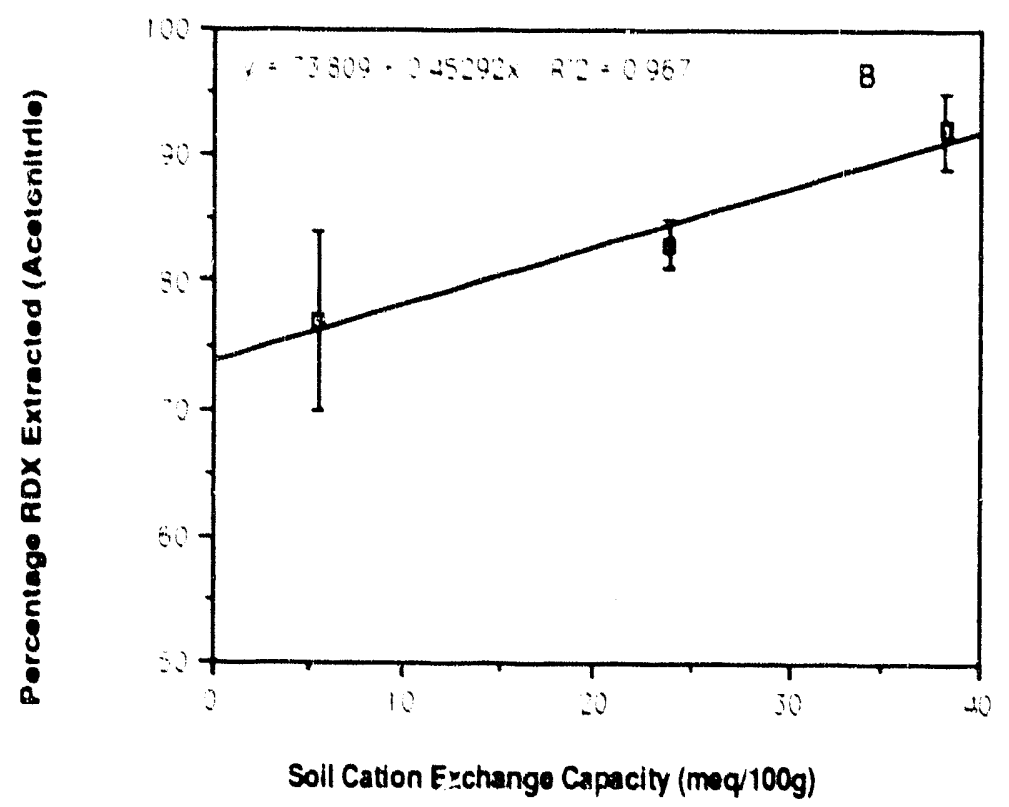

EIGURE 3.15. PLOTS OF RDX EXTRACTABILITY VERSUS (A) SOIL ORGANIC MATTER CONTENT AND (B) CATION EXCHANGE CAPACITY 

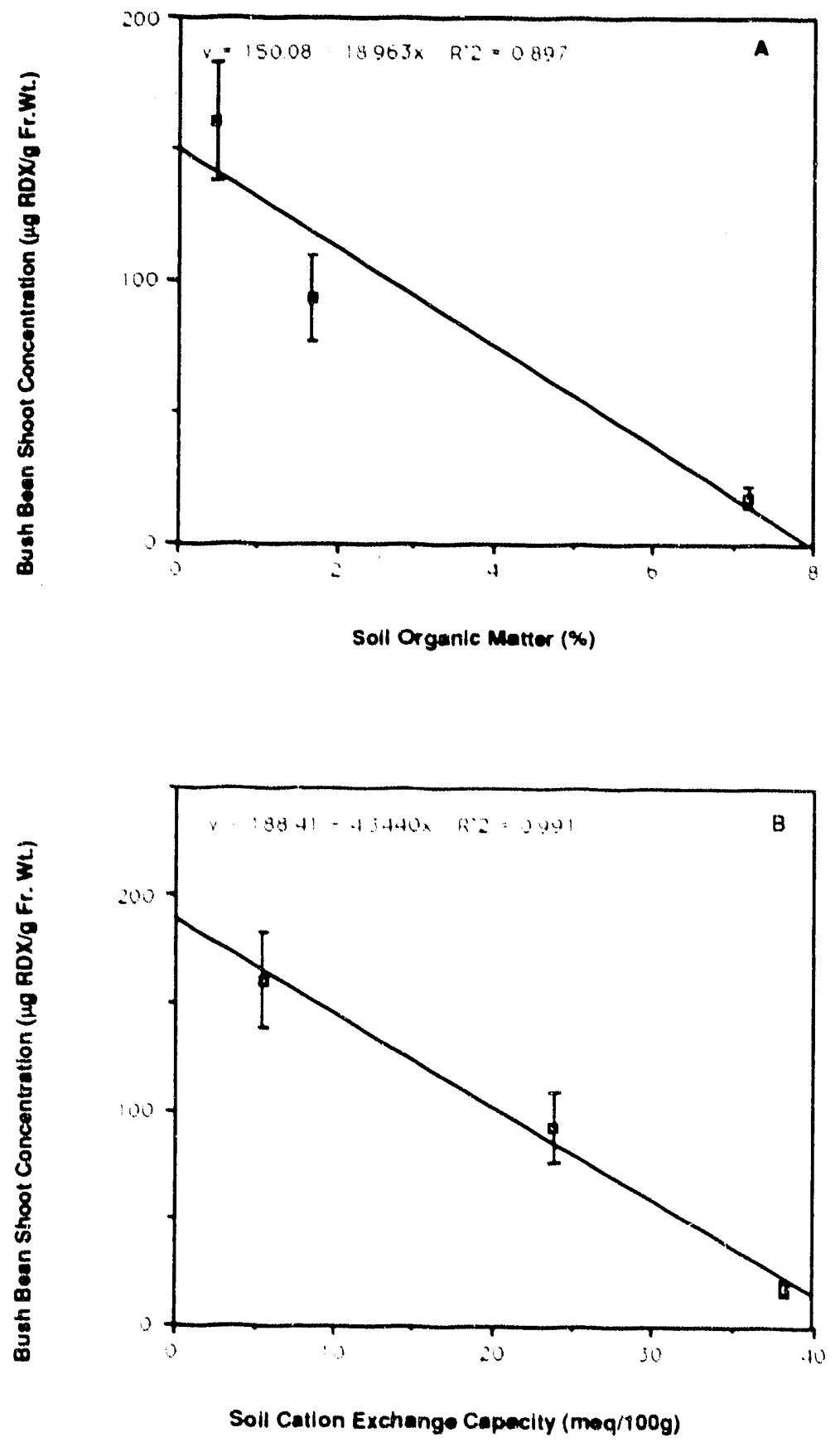

EIGURE 3.16. RELATIONSHIP OF (A) SOIL ORGANIC MATTER AND (B) CATION. EXCHANGE CAPACITY TO SHOOT RDX CONCENTRATIONS IN BUSH BEAN 

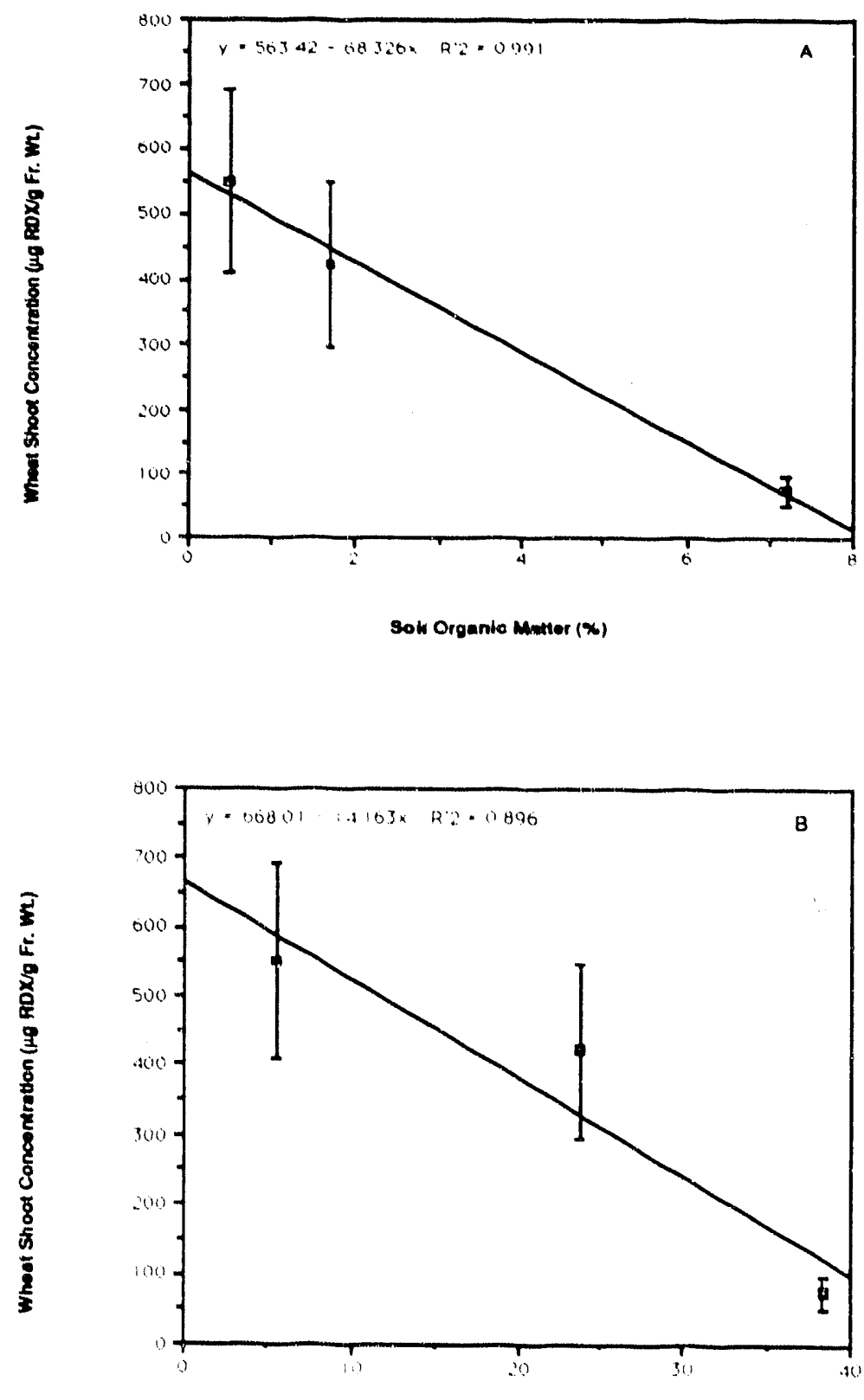

Soli Cetion Exchange Capeolty (neqroog)

EIGURE 3.17. RELATIONSHIP OF (A) SOIL ORGANIC MATTER AND (B) CATIONEXCHANGE CAPACITY ON SHOOT RDX CONCENTRATIONS IN WHIEAT 

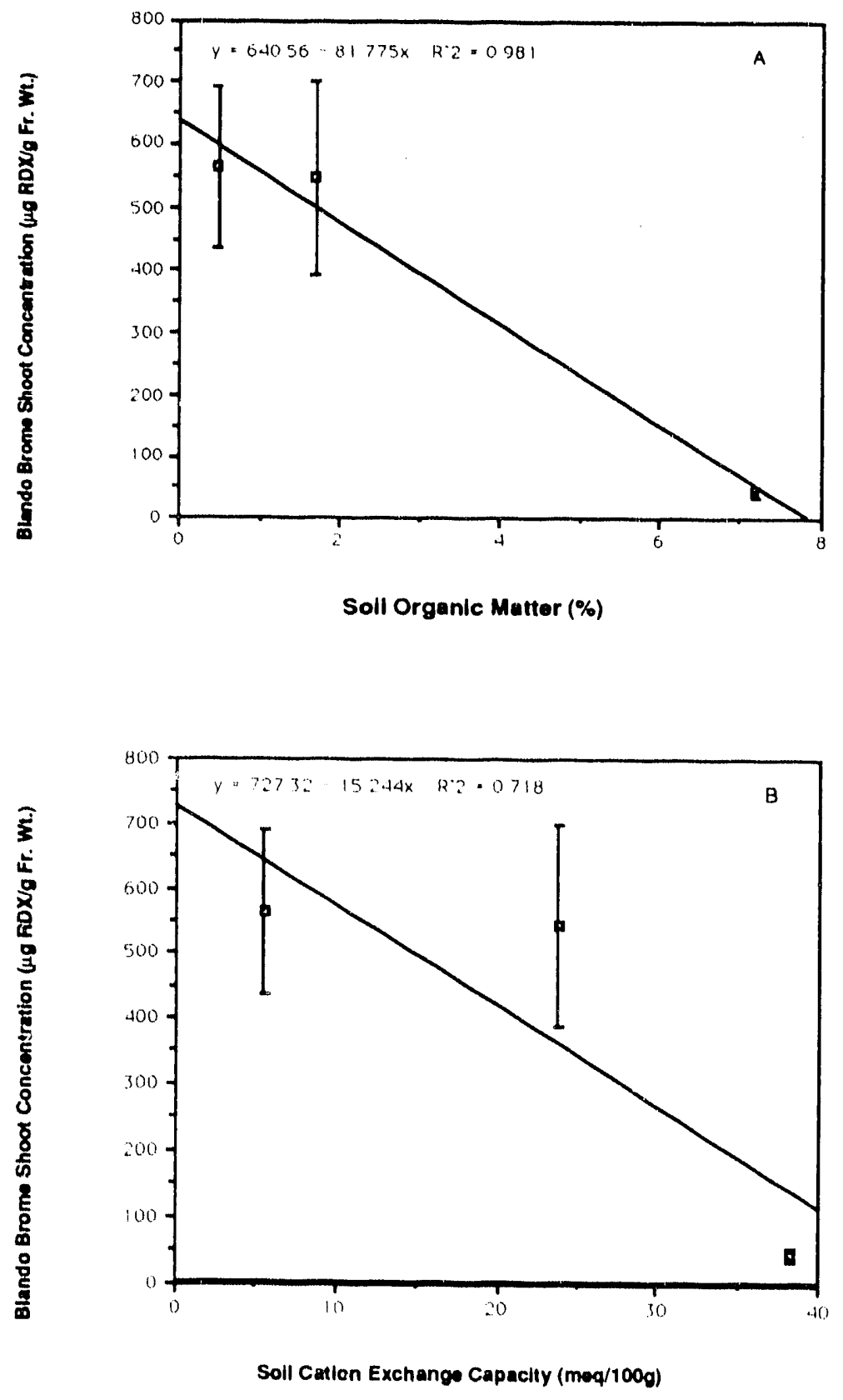

EIGURE 3.18. RELATIONSHIP OF (A) SOIL ORGANIC MATTER AND (B) CATIONEXCHANGE CAPACITY ON SHOOT RDX CONCENTRATIONS IN BLANDO BROME 


\subsection{SUMMARY AND CONCLUSIONS}

The goal of the present investigations was to elucidate the environmental behavior and fate of hexahydro-1,3,5-trinitro-1,3,5-triazine (RDX), particularly as related to its transport and chemical form in the food chain. To meet this goal, we needed to adapt and develop suitable analytical methodology to fractionate and characterize both RDX and RDX-derived residues in soil and plant matrices. Using the methodology that we developed, we assessed the chemical and physical fate of RDX in soils and plants. In general, the plant availability and plant mobility of RDX is substantially greater than that of TNT (Cataldo et al. 1990). In all cases, the form of RDX isoiated from tissues is greater than $50 \%$ RDX, the remainder being unidentified polar metabolites.

\subsection{RDX BEHAVIOR IN SOILS AND PLANTS}

\subsubsection{BDXFate in Soils}

Mass-balance analyses of RDX amended to soils varying in mineralogy, CEC, and organic-matter content were generally good, ranging from $100 \%$ at 11 days of incubation, to greater than $78 \%$ after 60 days. The extent of soil sorption of RDX after 60 days was less than $2 \%$, much less than that reported for TNT ( 31 in 50\%, Cataldo et al. 1990). Massbalance deficits were only partially attributed to mineralization of $\mathrm{RDX}$ to $\mathrm{CO}_{2}(<9.6 \mathrm{ng} /$ day, or $0.00023 \% /$ day, from $400 \mathrm{~g}$ pots amended at $10 \mathrm{ppm}$ ). No volatile organic residues were detected. Chemical analyses of solvent extracts of soils incubated for 60 days showed only the parent compound to be present, with no indication of metabolite formation, noted previously with TNT.

\subsubsection{Short-Term Hydropenic Studies}

Hydroponic plant-culture systems were used to establish absorption capacity and to develop chemical-fate procedures. The relative order of root absorption of RDX was bush bean > blando brome $>$ wheat. Plant absorption is concentration dependent, thus soilsorption processes should control the concentration of soil solution RDX and thus that fraction available for root uptake. Analysis of kinetic constants for root absorption of RDX indicated a metabolically mediated absorption process. Overall, uptake rates for RDX are less than those reported for TNT (Cataldo et al. 1990). 
In 2-h uptake studies, approximately $50 \%$ of the accumulated residues were retained within the root, while in 7-day studies the quantity of RDX retained in the roots declined to less than $20 \%$ of that accumulated. The plant mobility of RDX is substantially greater than that observed for accumulated TNT, greater than $90 \%$ of which was retained within the roots (Cataldo et al. 1990).

Analyses of the rates of RDX mineralization and residue volatilization for hydroponically grown plants indicated that no volatiles were released from either shoot- or rootaccumulated RDX residues. We observed some mineralization of accumulated RDX to ${ }^{14} \mathrm{CO}_{2}$ observed for the root/rhizosphere, amounting to a loss of $0.15 \% /$ day.

Chemical fractionation and analyses of 1- and 7-day hydroponically grown plants indicated that individual tissue chemical-class distribution patterns for RDX residues changed with duration of exposure. RDX residues contained in fraction F2 of 1-day bush bean leaves represent $86 \%$ of the total ether-extractable residues (acid-neutral + base), less than $1 \%$ of the extractable residues being associated with the slightly polar $\mathrm{F} 3$ fraction and only $5 \%$ with the Aq-base or highly polar fraction. After 7 days, $74 \%$ of the total etherextractable residues were associated with the F2 fraction, less than $14 \%$ of the extractable residues being associated with the slightly polar F3 and F4 fractions and 18\% vith the Aqbase fraction. Stem and root tissues of bush bean exhibited a similar temporal behavior, except that the concentration of RDX residues in the highly polar Aq-base fraction increased to approximately $50 \%$ of the total extractable activity. Very similar partitioning trends were observed for wheat and blando brome leaves and roots.

Chemical analysis of the F2 fractions clearly demonstrate that greater than $98 \%$ of the activity contained in these fractions is RDX. Thirty to fifty percent of the activity associated with the more-polar fractions (F2, F3, and Aq-base) was from modified polar forms. Analysis of xylem exudates, which contain the RDX transported from rovt to shoot tissues, shows the mobile transport form to be RDX, with less than $2 \%$ being a more-polar form.

\subsubsection{BDX Behavior in Mature Plants}

Studies with plants grown to maturity on RDX-amended soils show RDX-derived metabolites to accumulate in all tissues. The relative order of tissue concentration is seeci $>$ leaves $\geq$ stem $>$ root $>$ pod. In bush bean, the tissue concentrations for RDX-derived 
residues at maturity were as high as 200 and $600 \mu \mathrm{g} / \mathrm{g}$ fresh weight. for leaves and seed, respectively. Roots contained less than $75 \mu \mathrm{g} / \mathrm{g}$ fresh weight. In wheat and blando brome, leaf concentrations of RDX were as high as $550 \mu \mathrm{g} / \mathrm{g}$ fresh weight, and roots contained less than $45 \mu \mathrm{g} / \mathrm{g}$ fresh weight. Concentrations of RDX-derived residues in seeds from the grasses were as high as those in the leaves.

Fractionation and chemical analyses of plant tissues grown to maturity on soils amended with $10 \mathrm{ppm}$ RDX showed metabolism to more polar compounds to be more pronounced than that observed in 7-day hydroponic studies. In bush bean leaves, approximately $21 \%$ of the RDX-derived extractable residues existed in F2 as RDX, 30\% were in the form of extractable polar metabolites (ether base + F2 and F4), and 11 to $14 \%$ of the tissueaccumulated RDX residue was insoluble and contained in the pellet fraction following extraction. In stem tissue, and likely root tissue, 2 to $8 \%$ of the RDX-derived extractable residues existed in F2 as RDX, 30 to $40 \%$ were in the form of polar metabolites, and 30 to $50 \%$ of the tissue-accumulated RDX residue was insoluble and contained in the pellet fraction following extraction. Bush bean pods, with seeds, contained 2 to $10 \%$ of the RDXderived extractable residues as RDX, $50 \%$ were in the form of extractable polar metabolites, and $11 \%$ of the tissue-accumulated RDX residue was insoluble and contained in the pellet fraction following extraction. The behavior of RDX in the two grass species, wheat and blando brome, generally differed from the patterns seen with bush bean. In blando brome, 30 to $50 \%$ of the RDX-derived extractable residues existed in F2 as RDX, only 8 to $25 \%$ were in the form of polar metabolites, and $20 \%$ of the tissue-accumulated RDX residue was insoluble and contained in the pellet fraction following extraction. The partitioning of RDX in wheat was somewhat similar to that observed for bush bean. RDX-derived extractable residues isolated in $\mathrm{F} 2$ as $\mathrm{RDX}$ ranged from 6 to $29 \%, 17$ to $40 \%$ were in the form of polar metabolites, and $20 \%$ of the tissue-accumulated RDX residue was insoluble and contained in the pellet fraction following extraction.

Tissue partitioning and chemical analyses clearly indicate that RDX is the only nonpolar metabolite isolated from plants grown to maturity. RDX accounts for 6 to $53 \%$ of the accumulated residue activity in wheat and blando brome, 6 to $2 \%$ in bush bean leaves, and 2 to $10 \%$ in bean pods. Polar metabolites account for the vast majority of the remaining activity, much as seen with TNT (Cataldo et al. 1990). 


\subsubsection{BDX Behavior in Soil and Relative Plant Availability}

Total plant concentration is highly dependent on soil type, or soil-available RDX concentrations. In all cases, plant uptake was inversely proportional to soil organic-matter content for Burbank, Palouse and Cinebar soils. However, it is difficult to assign a mechanism by which RDX can be sorbed either to cation-exchange sites or organic matter, since RDX is nonpolar. Yet this sorption phenomenon does occur with RDX, as it did with TNT, where it was much more pronounced (Cataldo et al. 1990, Table 3.2). Extractability of TNT ranged from 37 to $60 \%$ after 60 days incubation.

Whatever is the phenomenon controlling RDX solubility in soil, it has a direct influence on the availability and tissue concentrations of RDX in plants. The tissue-accumulation and.concentration patterns observed clearly demonstrated that RDX is highly mobile within the plant and that the extent of uptake is characteristic of soil type. Correlations of plant concentrations of RDX with either CEC or soil organic matter, while showing distinct inverse relationships, are not consistent.

\subsection{RESEARCH NEEDS}

Results from soil studies indicate that RDX is not as tightly bound to soils as previously observed for TNT (Cataldo et al. 1990), with greater than 75\% of the amended RDX being solvent extractable. Also, no significant chemical transformations were seen with RDX incubated in soils for up to 60 days. However, soil/plant studies indicate that the plant availability of RDX is inversely proportional to those soil factors normally involved in sorption (CEC and organic matter content). Thus, soil processes are controlling the availability of RDX. It is therefore important to understand how nonpolar munitions materiels, including RDX, interact with soils.

The chemical fale of RDX, once accumulated by plants, is quite unique. RDX is very mobile compared with TNT (Cataldo et al. 1990), $<20 \%$ of the RDX being retained within the roots after 7 days in hydroponic systems. A similar plant mobility was seen with soil-grown plants. In soil-grown plants, seed tissues contained concentrations of RDX as high as or higher than those of leaves (200 to $600 \mathrm{ppm}$ ), indicating that RDX is likely phloem-mobile. The accumulation patterns for RDX would indicate that further studies should be conducted to evaluate food-chain transfer aspects. Further analysis of the soil/plant data indicates that the plants removed as much as $50 \%$ of the soil-amended RDX within one 60 -day growing 
cycle. This rather high plant-accumulation rate for RDX would suggest that biomining of RDX may be a viable environmental-remediation method and should be explored further.

Chemical analyses of leaves and seeds from mature plants indicated that 21 to $50 \%$ of the extractable RDX-derived residues are unaltered RDX, while 8 to $30 \%$ exist as metabolically altered polar residues, and 20 to $50 \%$ are not extractable. These chemical transformations, particularly in light of the high tissue concentrations observed, may be important from the standpoint of food-cisinin transfer and ecotoxicology. Studies should be initiated both to elucidate the chemical nature of polar residues and to resolve their importance in food-chain transfer. 


\subsection{LITERATURE CITED}

Bauer, C. F., C. L. Grant and T. F. Jenkins. 1986. "Interlaboratory Evaluation of High Performance Liquid Chromatographic Determination of Nitroorganics in Munition Plant Wastewater." Anal. Chem. 58:176-182.

Belkin, F., R. W. Bishop and M. V. Sheely. 1985. "Analysis of Explosives in Water and Capillary Gas Chromatography." J.Chromatoar. Sci. 24:532-534.

Cataldo, D. A., S. Harvey, R. J. Fellows, R. M. Bean, and B. D. McVeety. 1990. "An Evaluation of the Environmental Fate and Behavior of Munitions Materiel (TNT, RDX) in Soil and Plant Systems - Environmental Fate and Behavior of TNT." USAMBRDL Report ADA223546, National Technical Information Service, Springfield, Virginia.

Cataldo, D. A., T. R. Garland and R. E. Wildung. 1978. "Nickel in Plants 1. Uptake Kinetics Using Intact Soybean Seedlings." Plant Physiol. 62:563-565.

Cholakis, J. M., L. C. K. Wong, D. L. Van Goethem, J. Minor, R. Short, H. Spriny and H. V. Ellis, III. 1980. Mammalian Toxicological Evaluation of RDX. Final Report, DAMD 17-78-C8027, Midwest Research Institute, Kansas City, Missouri.

Glover, D.J. and J.D. Hoffsommer. 1979. "Photolysis of RDX in Aqueous Solution With and Without Ozone." NSWC/WOL-TR-78-175 (AD-A080195), Naval Surface Weapons Center, White Oak, Silver Springs, Maryland.

Hoffsommer, J.C., D.A. Kubose, and D.J. Glover. 1977. "Kinetic Isotope and Intermediate Formation for the Aqueous Alkaline Homogeneous Hydrolysis of 1,3,5-Triaza-1,3,5trinitrocyclohexane (RDX)." L. Phys, Chem. 81:380-85.

Jenkins, F. J. and C. L. Grant. 1987. "Comparison of Extraction Techniques for Munitions Residues in Soil." Anal. Chem. 59:1326-1331.

Jenkins, T. F., D. C. Leggett, C. L. Grant and C. F. Bauer. 1986. "Reversed-Phase HighPerformance Liquid Chromatographic Determination of Nitroorganics in Munitions Wastewater." Anal. Chem. 58:170-175.

Kaplan, A. S., C. F. Gerghour, and A. Poczenik. 1965. "Human Intoxification from RDX." Arch.Environ. Health 10:877-883.

Kearney, P. C., Q. Zeng and J. M. Ruth. 1983. "Oxidative Pre-Treatment Accelerates 2,4,6Trinitrotoluene Metabolism in Soils." Chemesphere 12:1583-1598. 
Kitchens, J. F., S. G. Brownlee, W. E. Hanward, R. G. Hyde, W. E. Jones, D. A. Price, R. S. Wentsel and R. S. Valentine. 1978. Preliminary Problem Definition Study on MunitionsRelated Chemicals. Final Report, DAMD17-77-C-7057, Atlantic Research Corp., Newark, New Jersey.

Klausmeier, R. E., J. L. Osmon and D. R. Wells. 1973. "The Effect of Trinitrotoluene on Microorganisms." Dev. Ind. Microbiol. 15:309-317.

McCormick, N.G., J.H. Cornell, and A.M. Kaplan. 1981. "Biodegradation of Hexahydro-1,3,5trinitro-1,3,5-triazine." Appl. Environ. Microbiol. 42:817-823.

McCormick, N. G., F. E. Feeherry and H. S. Levinson. 1976. "Microbial Transformation of 2,4,6-Trinitrotoluene and Other Nitroaromatic Compounds." Appl. Enviren. Microbiol. 31:949-958.

Merck Index. 1983. Tenth Edition, pp. 292-293. Merck \& Co., Inc., Rahway, New Jersey.

Nay, M. W., C. W. Randall and P. H. King. 1974. "Biological Treatment of Trinitrotoluene Manufacturing Wastewater." L.Water Pollut. Control Fed. 46:485-497.

Palazzo, A. J. and D. C. Leggett. 1986. "Effect and Disposition of TNT in a Terrestrial Plant." L.Environ. Qual. 15:49-52.

Ryon, M. G., B. C. Pal, S. S. Talamage and R. H. Ross. 1984. Database Assessment of the Health and Environmental Effects of Munition Production Waste Products. Final Report ORNL-6018, Oak Ridge National Laboratory, Oak Ridge, Tennessee.

Sax, N. I., and R. J. Lewis. 1989. "Dangerous Properties of Industrial Chemicals." Seventh Edition, Reinhold Publishing, New York, New York.

Schott, C. D. and E. G. Worthley. 1974. The Texicity of TNI and Related Wastes te an Aquatic Flowering Plant: Lemna perpusilla Torr Edgewood Arsenal, Technical Report No. EB-TR-74016, Edgewood, Maryland.

Sikka H. C., S. Banerjee, E. J. Pack and H. T. Appleton. 1980. Envirenmental Fate of RDX and INI. Final Report, DAMD17-\&\&-C-7026, Syracuse Research Corporation, Syracuse, New York.

Small, M. J. and D. H. Rosenblatt. 1974. Munitions Production Products of Petential Eencern - Phase 11 . Technical Report 7404. AD919031, U.S. Army Medical Bioengineering 
Laboratory, Fort Detrick, Frederick, Maryland.

Smock, L. A., D. L. Stoneburner and J. R. Clark. 1976. "The Toxic Effects of Trinitrotoluene (TNT) and its Primary Degradation Products on Two Species of Algae and Flathead Minnow." Water Res. 10:534-543.

Spanggord, R. J., T. W. Chou, T. Mill, R. T. Podoll, J. C. Harper, and D. S. Tse. 1985. Environmental Fate of Nitroguanidine. Diethylerialycol Dinitrate, and Hexachloroethane Smoke. Phase 1. DAMD17-84-C-4252. SRI International, Meno Park, California.

Spanggord, R. J., W. R. Mabey, T. W. Chou, S. Lee and P. L. Alferness. 1983a. Environmental Fate Studies of HMX. Phase 2, Detailed Studies. USAMBRDL Report ADA145122. National Technical Information Service, Springfield, Virginia.

Spanggord, R. J., W. R. Mabey, T. Mill, T. W. Chou, J. H. Smith, S. Lee and D. Roberts. 1983 b. Environmental Fate Studies on Certain Munitions Wastewater Constituents. Phase IVLageen Model Studies. Final Report, DAMD17-78-C-8081, SRI International, Menlo Park, California.

Spanggord, R. J., T. Mill, T. W. Chou, W. R. Mabey, J. H. Smith and S. Lee. 1980. Envirenmental Fate Studies on Certain Munition Wastewater Constituents. Phase IILaboratory Studies. Final Report, DAMD17-78-C-8081, SRI International, Menlo Park, California.

Spanggord, R. J., B. W. Gibson, R. G. Keck, D. W. Thomas, and J. J. Barkley, Jr. 1982. "Effluent Analysis of Wastewater Generated in the Manufacture of 2,4,6-Trinitrotoluene. 1. Characterization Study." Eviron. Sci. Technol. 16:229-232.

Yang, Y., X. Wang, P. Yin and P. Zhou. 1983. "Three Strains of Corynebacterium Degrading Cyclotrimethylenetrinitroamine." Acta Microbiol. Sin. 23:251-256. 

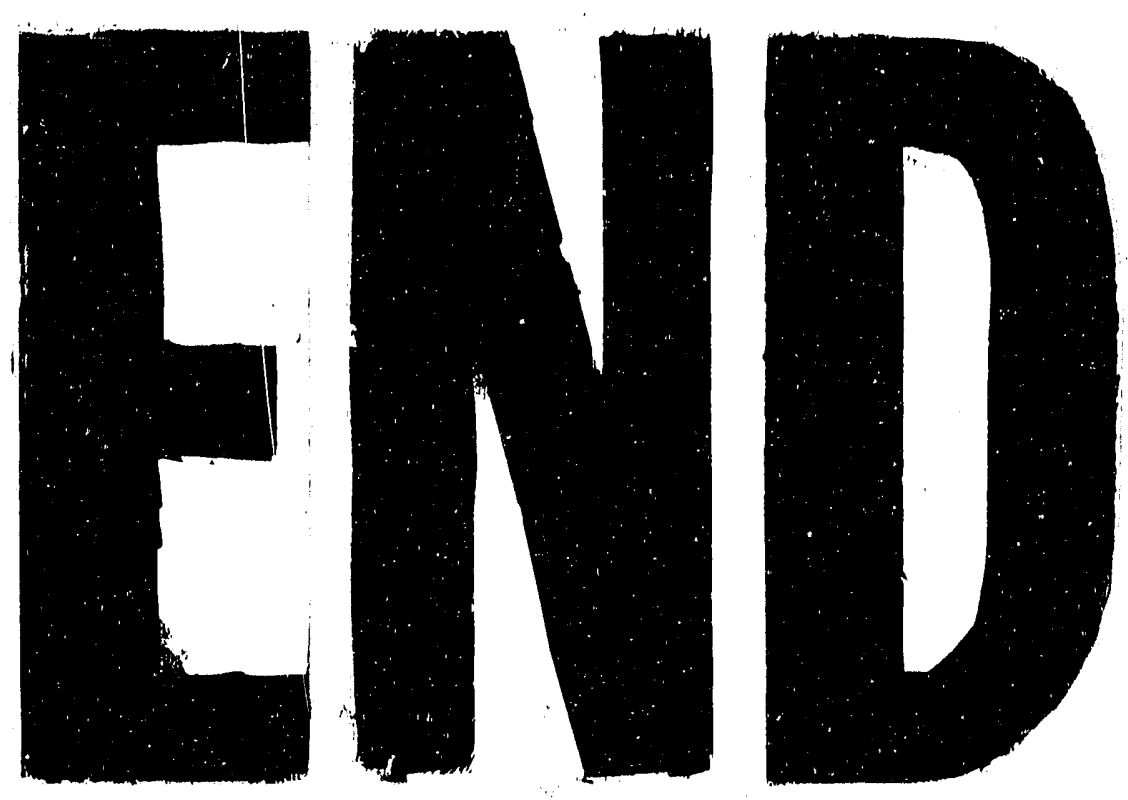

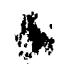
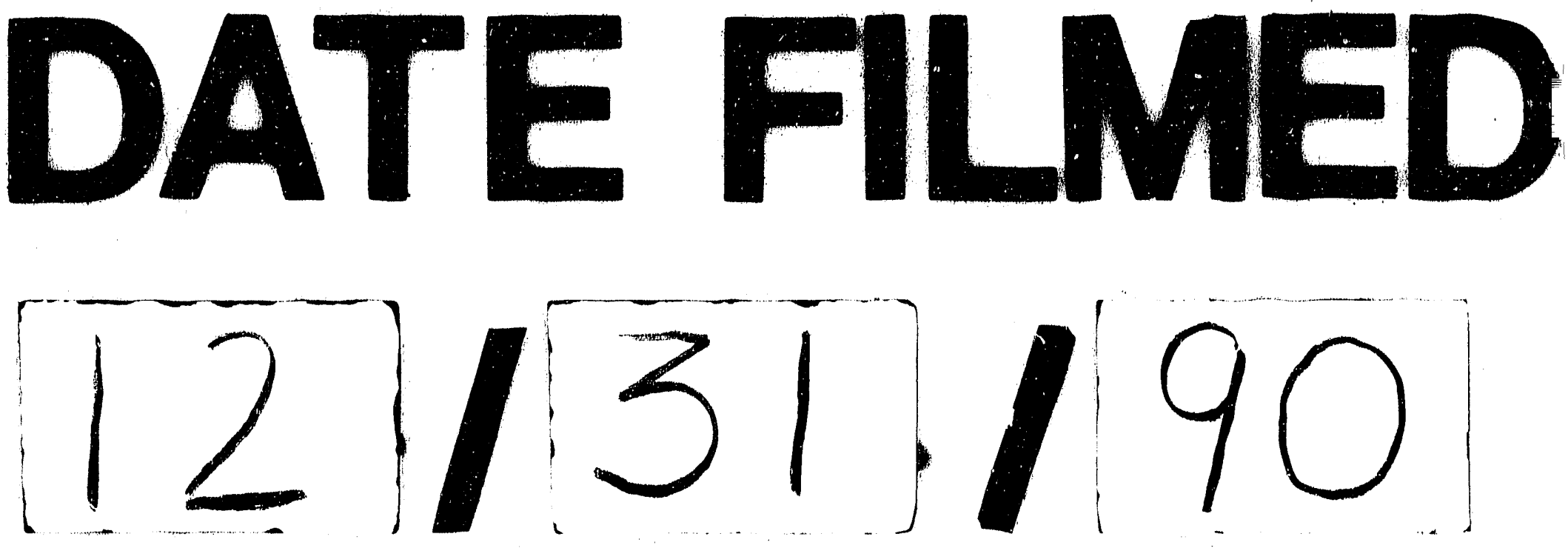
, 